UNIVERSIDADE DE SÃO PAULO

FACULDADE DE ECONOMIA, ADMINISTRAÇÃO E CONTABILIDADE DEPARTAMENTO DE CONTABILIDADE E ATUÁRIA PROGRAMA DE PÓS-GRADUAÇÃo EM CIÊNCIAS CONTÁBEIS

\author{
ESTUDO SOBRE AS DECISÕES IDENTIFICADAS NA GESTÃO \\ DE CONTRATOS DE JOGADORES DE FUTEBOL: \\ O CASO DO CLUBE ATLÉTICO PARANAENSE
}

Amaury José Rezende

Orientador: Prof. Dr. Carlos Aberto Pereira 
Prof. Dr. Adolpho José Melfi

Reitor da Universidade de São Paulo

Profa. Dra. Maria Tereza Leme Fleury

Diretora da Faculdade de Economia, Administração e Contabilidade

Prof. Dr. Reinaldo Guerreiro

Chefe do Departamento de Contabilidade e Atuária

Prof. Dr. Fábio Frezatti

Coordenador do Programa de Pós-Graduação em Ciências Contábeis 


\section{ESTUDO SOBRE AS DECISÕES IDENTIFICADAS NA GESTÃO DE CONTRATOS DE JOGADORES DE FUTEBOL: O CASO DO CLUBE ATLÉTICO PARANAENSE}

Dissertação apresentada ao Departamento de Contabilidade e Atuária da Faculdade de Economia, Administração e Contabilidade da Universidade de São Paulo como requisito para a obtenção do título de Mestre em Ciências Contábeis.

Orientador: Prof. Dr. Carlos Alberto Pereira 
Dissertação defendida e aprovada no Departamento de Contabilidade e Atuária da Faculdade de Economia, Administração e Contabilidade da Universidade de São Paulo Programa de Pós-Graduação em Ciências Contábeis, pela seguinte banca examinadora:

Rezende, Amaury José

Estudo sobre as decisões identificadas na gestão de contratos de jogadores de futebol: o caso do Clube Atlético Paranaense / Amaury José Rezende. -- São Paulo, 2004.

$190 \mathrm{f}$.

Dissertação (Mestrado) - Universidade de São Paulo, 2004

Bibliografia.

1. Contabilidade 2. Administração esportiva 3. Contratos Administração 4. Contratos 5. Eventos 6. Jogadores de futebol I. Faculdade de Economia, Administração e Contabilidade da USP II. Título.

CDD - 657 
A minha família que sempre acreditou na minha capacidade. 
Mostrar-me grato é o mínimo de sentimento que posso retribuir às pessoas que participaram e compreenderam o quanto era importante este desafio ao meu crescimento intelectual e humano. Assim, agradeço aos amigos, aos professores e aos funcionários da Universidade Federal de Mato Grosso do Sul - UFMS, pelo apoio recebido durante todos estes anos, em especial aos professores Jorge de Souza Pinto, Dercir Pedro de Oliveira, Tarcisio Rocha Athayde e Claudiornado Fragoso da Silva que não mediram esforços para que eu fizesse este mestrado.

Aos professores do Programa de Pós-graduação em Ciências Contábeis da FEA-USP que tanto contribuíram para meu crescimento científico e intelectual, em especial aos Professores Doutores Gilberto de Andrade Martins e Valmor Slomski.

Ao Professor Dr. Carlos Alberto Pereira, pela atenção, crítica, paciência, compreensão, rigor e apoio durante o processo de elaboração e discussão da dissertação.

Ao Conselho Federal de Contabilidade - CFC por seu apoio financeiro na concessão de bolsa de estudos e à Fundação Instituto de Pesquisas Contábeis, Atuariais e Financeiras - FIPECAFI, também por seu apoio financeiro na concessão de bolsa de estudos e viabilização da participação e discussão de pesquisas realizadas e apresentadas nos diversos congressos durante o período de mestrado.

Ao professor Dr. Ariovaldo dos Santos, em nome da Faculdade de Economia, Administração e Contabilidade da Universidade de São Paulo, pela oportunidade da realização deste curso de mestrado.

Ao Clube Atlético Paranaense que permitiu a realização dos estudos, em especial aos dirigentes e funcionários que se disponibilizaram e concederam entrevistas para a confecção desta dissertação.

Aos colegas do curso de mestrado Ariel, Cláudio, Aládio, Geraldo, Reinaldo, Paton, Igor, Erasmo, Márcio, Rogério, Lindinha, Rosa, Elza, Valdemar, Jesusmar, Paulo, Marcelo e Sandro.

Aos meus familiares, em especial aos meus pais Ary e Paulina e aos meus irmãos Letícia, Leir, Mara, Erivelto, Ary, Erica, Eide, Eine e Luiz e, por último, mas não menos importante, meu cunhado Eduardo. Agradeço a todos que acreditaram na minha capacidade.

Finalmente, agradeço à DEUS, Pai, fundamento de tudo, pela luz no caminho e por nunca ter me deixado perder a fé. 


\section{RESUMO}

Esta pesquisa tem como objetivo identificar os eventos, e suas respectivas variáveis, ligados ao processo de gestão de jogadores de futebol, de maneira que os gestores dos clubes possam avaliar e mensurar suas decisões. Para tanto, a investigação norteou-se pela seguinte questão de pesquisa: se o jogador de futebol é um ativo para o clube, então quais são as decisões (eventos) ligadas ao processo de gestão deste ativo e os seus impactos econômicos no resultado do clube? Dentre as estratégias de pesquisa utilizadas, destaca-se o método de estudo de caso, o qual foi imprescindível na investigação e no diagnóstico das variáveis de cada evento. A pesquisa constatou que os gestores têm consciência dos eventos, mas o clube não disponibiliza um sistema de avaliação para esses eventos. Deste modo, este trabalho propõe uma metodologia que permite aos gestores avaliarem a viabilidade econômica de suas decisões. Diante das evidências do estudo de caso e com base nos eventos estudados, estruturou-se uma solução para avaliação das decisões e mensuração do impacto econômico dessas decisões (comprar, vender, emprestar, renegociar, formar e permutar), proporcionando, assim, ao gestor parâmetros para o planejamento, avaliação e controle das transações relacionadas ao jogador de futebol. A proposta apresentada objetiva disponibilizar ferramentas que, de forma estratégica, contribuam para o desenvolvimento das relações financeiras, econômicas e sociais do clube. 


\begin{abstract}
The aim of the research is to identify the events, and their respective variables, related to the management process of soccer players, so that the club managers may evaluate and measure theirs decisions. For such purpose, the investigation was guided by the following research question: if the soccer player is an asset for the club, which are the decisions (events) related to the management of this asset and their economic impacts on the club results? Amongst the research strategies used, the method of case study is highlighted, which was indispensable to the investigation and diagnosis of the variables of each event. The research has evidenced that the managers are aware of the events, but an evaluation system of such events is not available at the club. Therefore, this paper proposes a methodology that allows the managers to evaluate the economic viability of their decisions. With the evidence found in the case study and based on the events studied, a solution was structured for the evaluation of the decisions and measurement of the economic impact of these decisions (to buy, to sell, to loan, to renegotiate, to form and to exchange), thus providing the manager with the parameters for the planning, evaluation and control of the transactions related to the soccer player. The aim of the proposal presented is to provide tools that contribute, in a strategic way, for the development of the financial, economic and social relations of the club.
\end{abstract}




\section{SUMÁRIO}

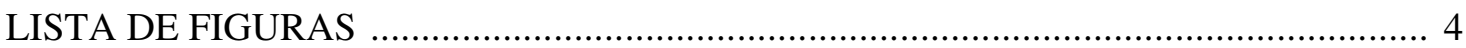

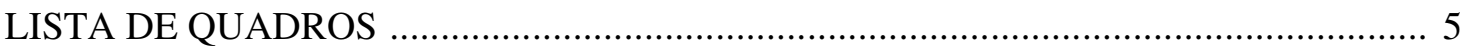

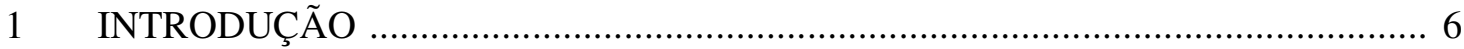

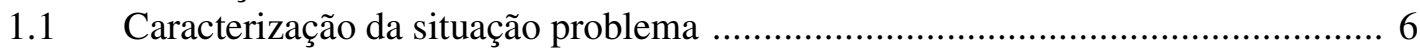

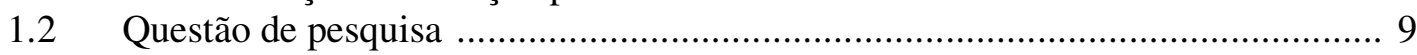

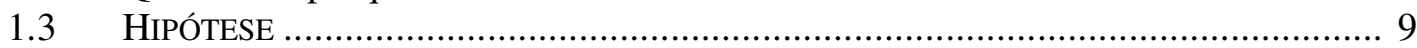

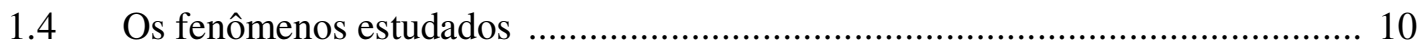

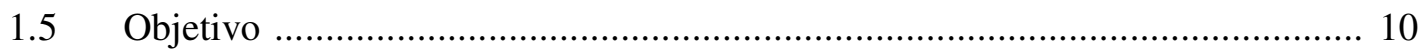

1.6 Metodologia e métodos de pesquisa ...................................................... 10

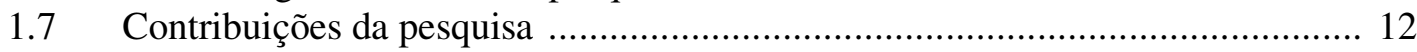

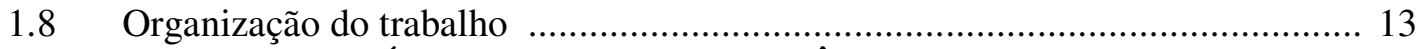

2 O CONTEXTO HISTÓRICO, SOCIAL E ECONÔMICO DO FUTEBOL ............... 14

$2.1 \quad$ História e prática do futebol no Brasil .............................................................. 14

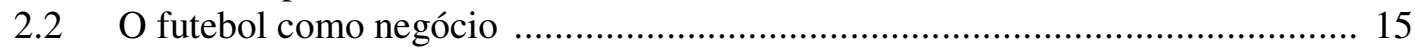

2.3 Aspectos sociais e econômicos do futebol ….............................................. 17

2.4 Cadeia de relacionamentos do futebol ...................................................... 18

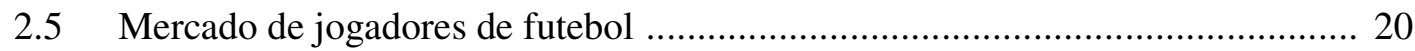

2.6 O fim de um "Impasse" ............................................................................. 22

2.7 Contratos - medida de segurança de clubes e jogadores ................................. 23

2.8 O Direito de Imagem - uma fonte de renda para os clubes ................................ 28

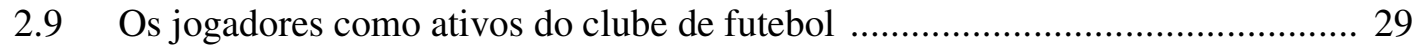

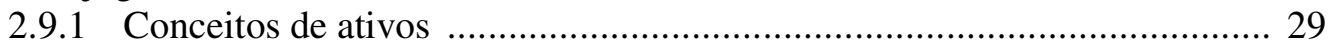

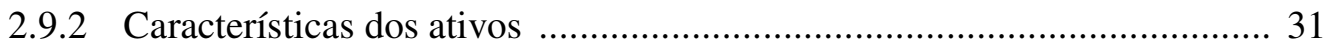

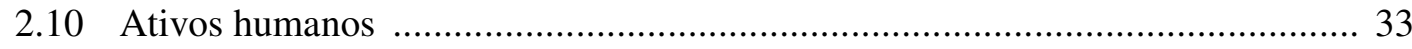

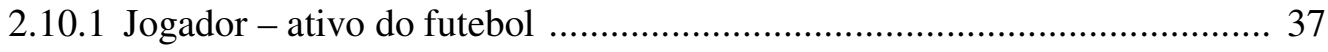

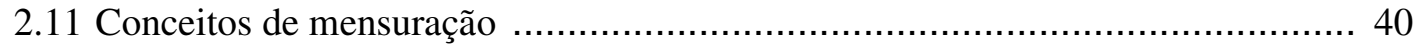

2.11.1 Etapas do processo de mensuração ...................................................... 43

2.11.2 A objetividade da mensuração contábil .............................................. 44

2.11.3 A atribuição de valor ao jogador e a relação com o clube ...................... 45

2.11.4 O processo de mensuração do jogador de futebol .................................. 46

3 A METODOLOGIA DE ESTUDO DE CASO ................................................. 49

3.1 Conceitos e definições ....................................................................... 49

3.1.1 Questões de pesquisa ............................................................... 49

3.1.2 Instrumento de coleta de dados .................................................. 50

3.1.3 Estratégias de pesquisas ............................................................ 50

3.1.4 Protocolos de pesquisa ................................................................ 54

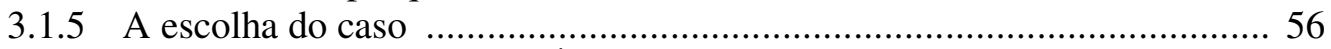

4 ESTUDO DE CASO - CLUBE ATLÉTICO PARANAENSE ............................. 58

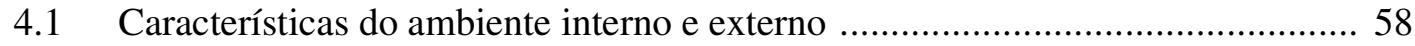

4.1.1 Aspectos históricos ................................................................. 58

4.1.2 Mercados, clientes, fornecedores e concorrentes …............................. 58

4.1.3 Governo, federações e legislações vigentes ........................................ 62

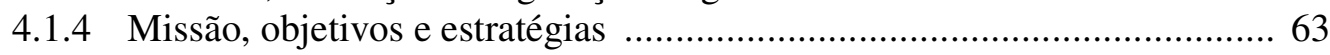

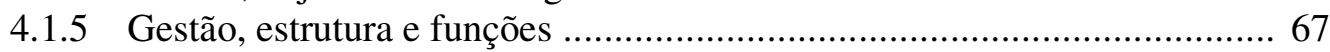

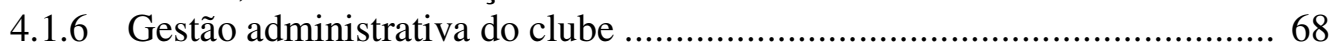

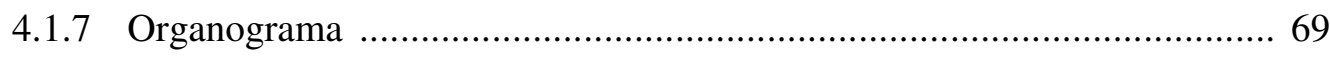

4.1.8 Sistemas de informações e a gestão ................................................ 71 
4.1.9 O sistema contábil do clube .......................................................... 72

4.1.10 A importância do orçamento ............................................................ 73

4.1.11 Ativos, passivos e o patrimônio do clube ............................................. 73

4.2 Processo físico-operacional de formação de jogadores de futebol ...................... 74

4.2.1 Os requisitos para seleção de talentos ................................................. 75

4.2.2 As fases de formação de jogador ........................................................ 77

4.2.3 PIRÂMIDE DE FORMAÇÃO .................................................................. 79

4.2.4 Clube como uma indústria de formação de jogadores ............................ 80

4.2.5 A importância do processo científico na formação de atletas .................. 83

4.3 Metodologia e parâmetros na avaliação dos eventos ligados à gestão dos atletas

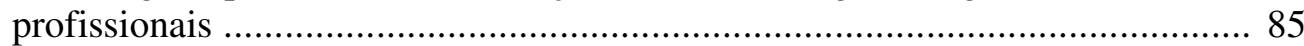

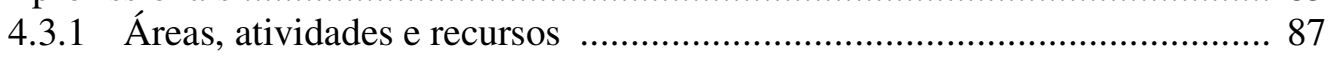

4.3.2 O gerenciamento da carreira dos atletas .......................................... 89

4.3.3 Custos de formação e manutenção de atletas .......................................... 90

4.3.4 O processo de contratação de jogadores ............................................... 91

4.3.4.1 Variáveis relevantes para o processo de contratação ..................... 93

4.3.5 Processo de negociação de jogadores - venda ......................................... 94

4.3.6 O valor de mercado do atleta está relacionado com a sua posição em

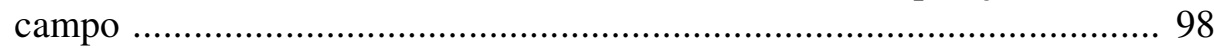

4.3.7 Decisão de empréstimos de jogadores ............................................... 99

4.3.8 A decisão - permuta de jogadores ............................................... 101

4.3.9 Contratos e renegociações de contratos .............................................. 101

4.3.10 Remuneração e prêmios dos atletas profissionais e amadores ............... 104

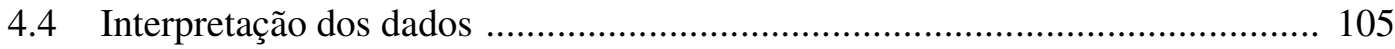

4.4.1 O processo de negociação de jogadores e o contexto dos eventos .......... 106

4.4.2 Caracterização dos eventos ............................................................. 106

5 MODELOS DE DECISÃO DOS EVENTOS ECONÔMICOS IDENTIFICADOS NA

GESTÃO DE CONTRATOS DE JOGADORES DE FUTEBOL …....................... 110

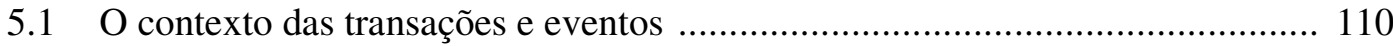

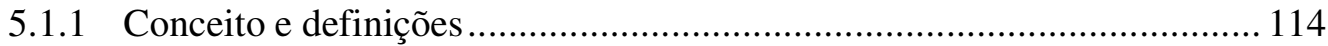

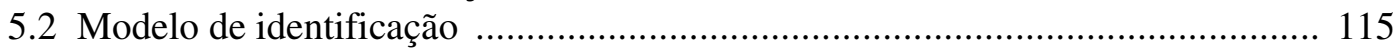

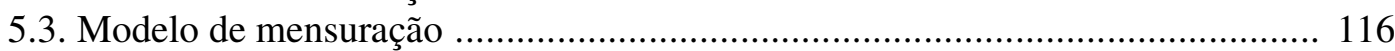

5.3.1 Conceitos e definições ............................................................... 116

5.3.2 Metodologias de avaliação ........................................................... 117

5.3.3 Custo de oportunidade como medida de avaliação ................................. 121

5.3.4 Fundamentos do modelo de mensuração .......................................... 124

5.3.4.1 O valor econômico - ativo .............................................. 124

5.3.4.2 O valor de mercado - ativo ................................................. 126

5.3.4.3 A lógica do modelo de mensuração ....................................... 126

5.3.4.4 Detalhamento do modelo de mensuração ............................... 129

5.3.4.5 O modelo de mensuração .................................................... 130

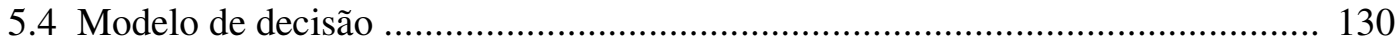

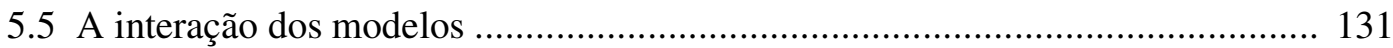

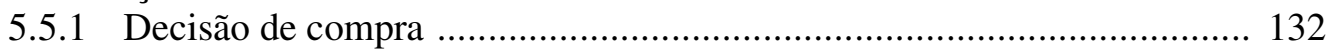

5.5.1.1 Características do evento ................................................. 133

5.5.1.2 Variáveis identificadas ....................................................... 133

5.5.1.3 Apuração do resultado do evento compra ................................ 134

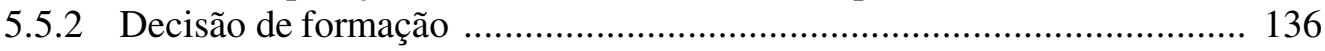

5.5.2.1 Os atletas formados pelos clubes ......................................... 136

5.5.2.2 Apuração do resultado do evento formação ............................ 139 


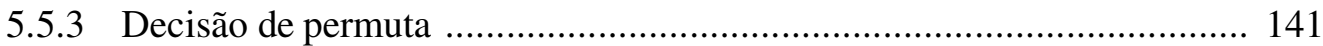

5.5.3.1 Características do evento ..................................................... 141

5.5.3.2 Variáveis identificadas ........................................................ 141

5.5.3.3 Apuração do resultado do evento permuta ............................. 142

5.5.4 Decisão de empréstimo (obtenção) .................................................... 143

5.5.4.1 Características do evento .................................................... 144

5.5.4.2 Variáveis identificadas ......................................................... 144

5.5.4.3 Apuração do resultado do evento obtenção de empréstimo ...... 144

5.5.5 Decisão de empréstimo (concessão) ................................................. 145

5.5.5.1 Características do evento .................................................. 146

5.5.5.2 Variáveis identificadas ....................................................... 146

5.5.5.3 Apuração do resultado do evento concessão de empréstimo ..... 144

5.5.6 Decisão de venda .................................................................... 148

5.5.6.1 Características do evento ................................................... 148

5.5.6.2 Variáveis identificadas ........................................................ 148

5.5.6.3 Apuração do resultado do evento venda ................................. 149

5.5.7 Decisão de renegociação de contratos ............................................... 151

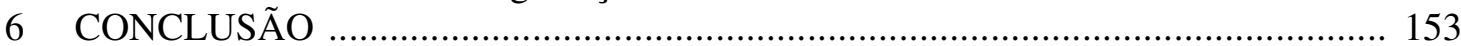

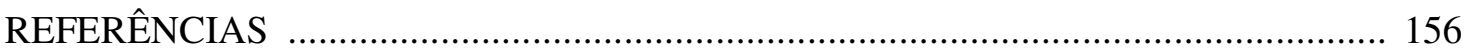

APÊNDICES

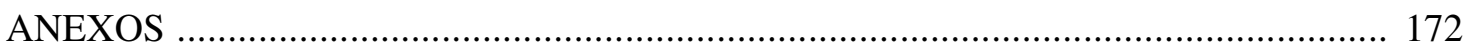




\section{LISTA DE FIGURAS}

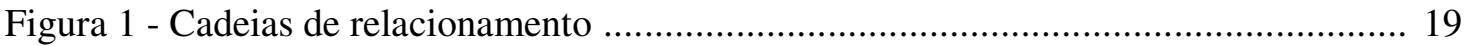

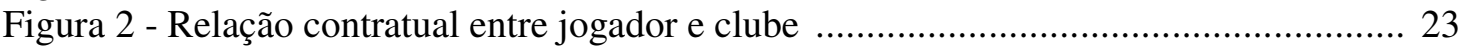

Figura 3 - Cadeia agente-principal - clube de futebol ................................................ 27

Figura 4 - Modelo de mensuração no segmento esportivo ......................................... 42

Figura 5 - Convergências de várias fontes de evidências (estudo único) ........................... 51

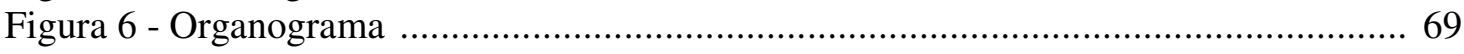

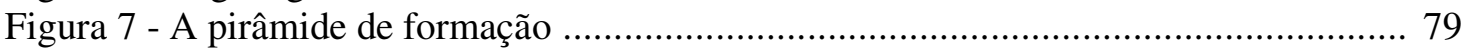

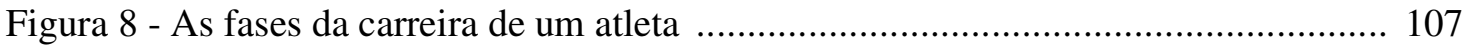

Figura 9 - O eventos ou decisões entre clube - atletas ............................................ 112

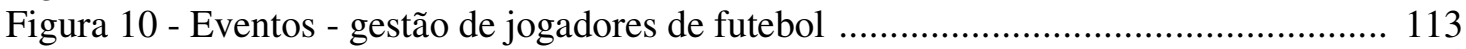

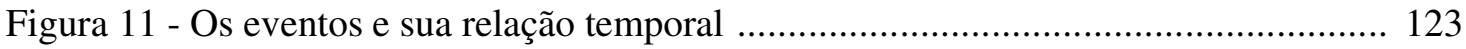

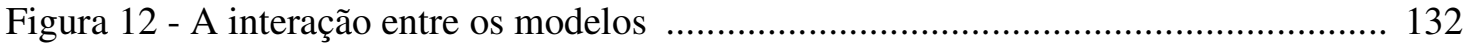

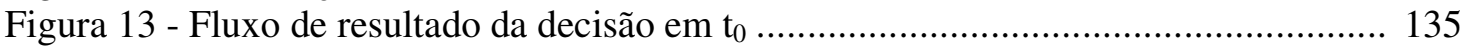

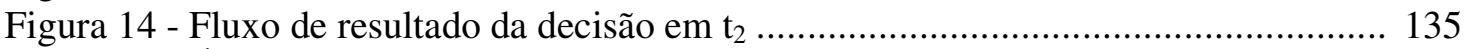

Figura 15 - Árvore de decisão para jogadores em formação ........................................ 137

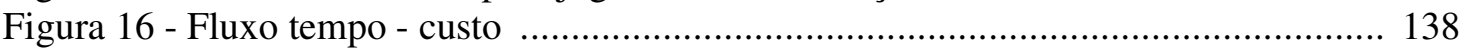

Figura 17 - Árvore de decisão: custos e probabilidade (jogadores em formação) ........... 139

Figura 18 - Fluxo da apuração do resultado do evento - formação .............................. 140

Figura 19 - Fluxo físico-operacional - contratos e renegociações ................................. 151 


\section{LISTA DE QUADROS}

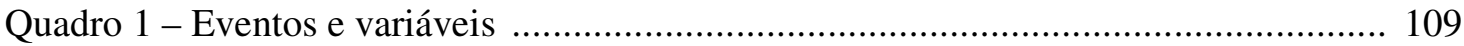

Quadro 2 - Modelo de identificação ............................................... 115

Quadro 3 - Modelo de mensuração ......................................................................... 130

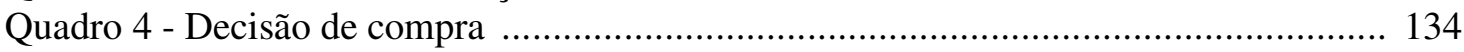

Quadro 5 - Cálculos dos atletas em formação .............................................................. 136

Quadro 6 - Cálculo de custos - por categoria .......................................................... 138

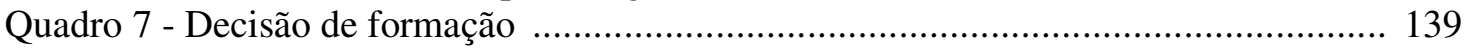

Quadro 8 - Decisão de permuta - jogador A …...................................................... 142

Quadro 9 - Decisão de permuta - jogador B ........................................................... 143

Quadro 10 - Decisão de empréstimo (obtenção) ....................................................... 145

Quadro 11 - Decisão de empréstimo (concessão) ........................................................ 147

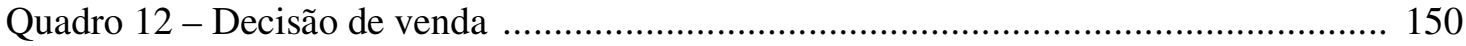




\section{INTRODUÇÃO}

O futebol representa uma das atividades esportivas mais praticadas no mundo, tendo o jogador como astro principal do espetáculo. O presente estudo trata das decisões ligadas à gestão de jogadores de futebol. De forma específica, a base da investigação deu-se sobre a questão: se o jogador de futebol é um ativo para o clube, quais são as decisões (eventos) ligadas ao processo de gestão desse ativo e os seus impactos econômicos no resultado do clube? Para responder a questão levantada, este trabalho utilizou-se de pesquisa bibliográfica e da metodologia de estudo de caso.

A pesquisa visa auxiliar os gestores no processo de tomada de decisão, no que diz respeito ao processo de negociação de jogadores de futebol, o que normalmente envolve valores expressivos em relação ao patrimônio do clube.

\subsection{Caracterização da situação problema}

A gestão do futebol apresenta características que diferem das demais atividades, principalmente porque o fator psicológico-emocional está presente nas decisões e leva os gestores a tomá-las considerando a emoção em detrimento da razão. Assim, os clubes necessitam cada vez mais adotar sistemas de informações que ofereçam subsídios e auxiliem na tomada de decisão.

Tal necessidade é corroborada por Edwards apud Aidar (2000, p. 15), quando destaca a seguinte afirmação do presidente do Manchester United: "[...] contratar um jogador sem obedecer a qualquer orçamento e sem saber se seus salários poderão ser pagos é um exemplo típico de decisão com base na emoção."

Tendo em vista que essas decisões normalmente envolvem valores significativos em relação ao patrimônio do clube, a contabilidade deveria subsidiar o processo de negociação destes ativos, permitindo aos gestores conhecer o impacto econômico de cada decisão no resultado do clube. 
Hendriksen e Van Breda (1999, p. 135) consideram que a função da contabilidade é “[...] fornecer informação quantitativa, principalmente de natureza financeira, sobre as entidades econômicas, de utilidade para a tomada de decisões econômicas."

Visto que, a cada temporada, os clubes necessitam modificar suas equipes em função do desempenho, renovação do elenco, aquisição de novas peças de reposição, os gestores tomam decisões de adquirir, vender, emprestar, renovar contratos e até permutar seus atletas.

Essas decisões impõem uma série de desafios aos gestores, tais como: Em que momento contratar? Como avaliar seus jogadores? Em que momento vender? Quando o clube deveria emprestar? Qual a vantagem econômica da permuta? Interessa ao clube renovar o contrato? Qual o resultado de formar um atleta?

É diante destas indagações que os gestores tomam ou têm de tomar decisões que normalmente envolvem valores expressivos dos recursos financeiros do clube.

Esses recursos financeiros envolvidos nas transações com jogadores de futebol demonstram como esta questão merece uma atenção especial dos gestores. Além disso, os salários representam os maiores custos, ou seja, os salários dos jogadores consomem grande parte dos recursos financeiros dos clubes, gerando uma situação insustentável. Para Garred21 (2002), o segredo para estabelecer um modelo de negócio correto é olhar para as operações do futebol como centro de comércio.

Atualmente, quando se fala do valor de um jogador de futebol, observa-se apenas o quanto foi desembolsado (pago), ou o valor de negociação, e seu valor contábil, o que se verifica apenas em valores históricos.

Vale lembrar que os procedimentos e práticas contábeis dos clubes de futebol não permitem a mensuração dos efeitos causados pelas decisões sobre os resultados dos clubes, sendo que o valor desembolsado pelos clubes, na atualidade, ao contratar ou formar um atleta, não é tratado como investimento e sim como despesas do período, o que impacta de forma

\footnotetext{
${ }^{21}$ Especialista da Leeds University Business School em finanças do futebol; proferido em Conferência em Londres em discussão sobre estratégias para receitas no futebol, onde delegados e palestrantes destacaram a necessidade de reformas nos modelos de negócios no futebol.
} 
significativa o resultado e o patrimônio da entidade. Uma vez que estes investimentos irão proporcionar benefícios econômicos presentes e futuros, a entidade deveria tratá-los como um ativo.

No caso da formação de atletas, o clube formador ativa os gastos incorridos pelo custo histórico, o que não reflete a realidade econômica destes ativos para a entidade. Deste modo, os ativos não estão expressos individualmente por seu verdadeiro valor para o clube (valor econômico) e, conseqüentemente, os resultados não refletem as variações da riqueza econômica do clube, nem seu patrimônio reflete o valor econômico do clube.

Os eventos ou decisões decorrentes da gestão destes ativos deveriam ter como parâmetro informações suficientes para atender as necessidades dos gestores dessas organizações, de modo a permitir a otimização dos seus resultados econômicos.

O reconhecimento de resultados com base no custo histórico não apenas distorce a representação da realidade econômica do clube, como também quebra um princípio básico de gestão de qualquer negócio: o princípio da controlabilidade.

De acordo com Pereira (2000), os custos históricos são decorrentes de uma decisão que não é mais passível de gestão, mas sim os seus efeitos presentes e futuros sobre o empreendimento, uma vez que custos históricos pertencem ao passado e o passado não é mais controlável.

Desse modo, resumem-se abaixo as principais variáveis que caracterizam a situação problema, na qual se insere a questão de pesquisa deste trabalho:

- $\quad$ Decisões baseadas na emoção;

- Decisões que envolvem volumes expressivos de recursos financeiros;

- A contabilidade deveria gerar informações sobre o impacto desses ativos sobre o patrimônio do clube, bem como sobre seus resultados;

- A contabilidade dos clubes, porém, está baseada nos princípios tradicionais de contabilidade, de modo que seus ativos, passivos e conseqüentemente seu patrimônio são registrados pelos seus valores históricos;

- Valores históricos não são mais controláveis; 
- Daí a importância de identificar as decisões (eventos) e mensurar seus impactos econômicos, de modo a permitir que os gestores simulem, planejem e controlem tais efeitos, visando assegurar a continuidade do clube;

- Carência de estudos na área contábil sobre o tema;

- $\quad \mathrm{Na}$ pesquisa bibliográfica sobre o tema, realizada preliminarmente, não foram identificados estudos que comprovem que o jogador de futebol deva ser tratado como ativo para o clube;

- Do mesmo modo, não foi constatada a existência de estudo sobre o processo de gestão de jogador de futebol no Brasil, nem sobre as decisões especificamente tomadas neste processo.

\subsection{Questão de pesquisa}

Considerando que as decisões tomadas em relação aos jogadores de futebol geram impactos econômicos para o clube, faz-se necessário um estudo mais profundo sobre estes eventos.

De maneira sintética aponta-se a seguinte questão, como orientadora do presente estudo: Se o jogador de futebol é um ativo para o clube, então quais são as decisões (eventos) ligadas ao processo de gestão deste ativo e os seus impactos econômicos no resultado do clube?

\subsection{Hipótese}

Para responder esta questão, parte-se da hipótese de que o jogador de futebol é um ativo para o clube. Desse modo, como conseqüência dessa afirmação, entende-se que a contabilidade deva identificar os eventos (modelo de identificação), mensurar seus impactos econômicos no resultado do clube (modelo de mensuração) e estruturar os modelos de decisão para cada evento identificado, como forma de subsidiar o processo de gestão do jogador com informações relevantes para a tomada de decisão sobre este ativo. 


\subsection{Os fenômenos estudados}

Este trabalho tem por objeto o estudo das decisões ligadas à gestão de contratos de jogadores de futebol e os seus impactos econômicos no resultado do clube.

\subsection{Objetivo}

O objetivo do trabalho é identificar os eventos e suas respectivas variáveis de maneira que os gestores dos clubes possam avaliar e mensurar as decisões ligadas ao processo de negociação de jogadores de futebol, bem como identificar as principais decisões e parâmetros relevantes ao processo decisório. Para tanto, estabeleceram-se os seguintes objetivos específicos, os quais nortearam a realização do trabalho:

- Descrever o ambiente (externo e interno) em que ocorrem as decisões no contexto de um clube de futebol, bem como conceituar e caracterizar o jogador como ativo e sua relevância para o patrimônio da entidade;

- Identificar os eventos, o conjunto de variáveis e as características no processo de avaliação dos ativos no clube estudado;

- Estruturar um modelo de identificação, mensuração e decisão dos eventos apontados pela pesquisa; e

- Simular a aplicação do modelo proposto para cada decisão ou evento, demonstrando o seu impacto econômico no resultado do clube.

\subsection{Metodologia e métodos de pesquisa}

A metodologia consiste nos estudos dos métodos empregados pelas ciências na investigação sobre o comportamento de certos fenômenos, buscando validação e sua relação com as teorias científicas (LAKATOS; MARCONI, 1991, p. 18-20).

De acordo com Trujillo apud Lakatos e Marconi (1991, p. 39), 
[...] método é a forma de proceder ao longo de um caminho. Na ciência os métodos constituem os instrumentos básicos que ordenam de início o pensamento em sistemas, traçam de modo ordenado a forma de proceder do cientista ao longo de um percurso para alcançar um objetivo.

\section{Lakatos e Marconi (2003, p. 83) definem:}

[...] método é o conjunto das atividades racionais que, com maior segurança e economia, permite alcançar o objetivo - conhecimentos válidos e verdadeiros - traçando o caminho a ser seguido, detectando erros e auxiliando as decisões científicas.

Observa-se a importância do planejamento do método ou do caminho a ser percorrido durante a pesquisa, e também sua contribuição para a realização e o sucesso da pesquisa. De forma específica, a metodologia utilizada como suporte para a realização da primeira etapa deste estudo foi o método hipotético-dedutivo, por meio do qual, segundo Kaplan (1972, p. 12),

[...] o cientista através de uma combinação de observações cuidadosas, hábeis antecipações e intuição científica, alcança um conjunto de postulados que governam os fenômenos pelos quais está interessado; daí deduz ele as conseqüências observáveis; a seguir, verifica essas conseqüências por meio da experimentação e, dessa maneira, refuta os postulados substituindo-os, quando necessário, por outros e assim prossegue.

O método hipotético-dedutivo foi importante no processo de validação dos pressupostos teóricos deste trabalho, no qual se buscou evidência na literatura para demonstrar se o jogador de futebol atende aos requisitos para ser tratado como ativo para o clube.

A segunda etapa do trabalho consiste em uma pesquisa de campo que, de acordo com Martins (1992, p.26), “[...] são abordagens que representam em comum a utilização de técnica de coleta, tratamento e análise de dados marcadamente quantitativos."

Dentre as estratégias utilizadas nesta pesquisa destaca-se também o estudo de caso, que teve como objetivo a identificação dos eventos (decisões) e das variáveis vinculadas à gestão destes ativos "jogadores de futebol".

Segundo Yin (2001, p. 35), o estudo de caso é uma estratégia de pesquisa como qualquer outra "[...] que representa uma maneira de se investigar um tópico empírico, seguindo-se um conjunto de procedimentos pré-especificados." 
Esta fase foi importante na identificação dos eventos e das variáveis que influenciam cada decisão ligada à gestão de jogador de futebol no clube. Entretanto, a abordagem metodológica do estudo de caso utilizada na fase empírica da pesquisa será discutida no capítulo 3.

Esta pesquisa caracteriza-se por dois critérios básicos que, segundo Vergara (2003, p.46-47), são assim definidos:

quanto aos meios - pesquisa bibliográfica, documental e de campo;

quanto aos fins - pesquisa explicativa.

A terceira etapa, a partir das variáveis diagnosticadas de cada evento ou decisão na pesquisa com os gestores do clube pesquisado, tem como objetivo a estruturação e a elaboração de uma proposta para avaliação das decisões com base na teoria da contabilidade, à luz dos conceitos econômicos de mensuração.

Esta última etapa tem objetivo comprobatório, utilizando-se de um exemplo com dados originários do caso estudado, com o intuito de verificar a praticabilidade do modelo proposto.

A partir do exemplo utilizado, busca-se demonstrar a aplicação dos modelos de decisão propostos a dados hipotéticos, por meio de simulações numéricas.

\subsection{Contribuições da pesquisa}

Por se tratar de uma pesquisa exploratória, num primeiro momento, este trabalho oferece evidências sobre o processo de gestão de jogadores de futebol, ou seja, uma compreensão dos seus principais eventos (decisões), parâmetros e variáveis no clube pesquisado.

Entende-se que os resultados desta pesquisa podem contribuir para a mudança qualitativa da visão que os gestores possuem sobre o processo de avaliação de jogadores de futebol, não só nos aspectos relacionados com os preços praticados no mercado, mas também numa visão econômica sobre o potencial de cada ativo e seu uso. 
Diante das evidências do estudo de caso e, com base nos eventos estudados, estrutura-se uma solução para avaliação das decisões e mensuração do impacto econômico das decisões (comprar, vender, emprestar, renegociar, formar e permutar). Assim, busca-se proporcionar ao gestor parâmetros para o planejamento, avaliação e controle das transações relacionadas ao jogador de futebol.

\subsection{Organização do trabalho}

Este trabalho está estruturado conforme segue:

No Capítulo 1 - apresentam-se os aspectos metodológicos da pesquisa.

No Capítulo 2 - discutem-se aspectos históricos, sociais e econômicos do futebol, os jogadores como ativo e sua relevância para o patrimônio do clube. Caracterizando como o contexto e o referencial teórico da pesquisa.

No Capítulo 3 - busca-se conceituar e caracterizar a abordagem metodológica utilizada no estudo de caso.

No Capítulo 4 - apresentam-se os relatos do estudo de caso como: o processo de gestão, as variáveis ligadas às decisões tomadas em relação aos ativos (jogador).

No Capítulo 5 - apresenta-se uma proposta de solução para a gestão destes ativos, em que se realizam simulações de maneira a validar a proposta apresentada, de forma que os gestores possam mensurar o impacto econômico e o resultado de cada decisão.

No Capítulo 6 - são apresentadas as conclusões do estudo, em relação à questão de pesquisa, bem como sugestões para novas pesquisas. 


\section{O CONTEXTO HISTÓRICO, SOCIAL E ECONÔMICO DO FUTEBOL}

Este capítulo tem como objetivo caracterizar os aspectos históricos, sociais e econômicos do futebol, constituindo um referencial teórico que sustenta as proposições vinculadas ao objeto da pesquisa. De forma específica, busca-se descrever o cenário no qual ocorrem os eventos ou decisões vinculadas à gestão de "jogadores de futebol". Para isto, fazem-se necessários alguns esclarecimentos sobre a evolução do futebol no Brasil, os relacionamentos sociais e econômicos, os mercados do futebol, o processo de negociação de "jogadores de futebol" e os mecanismos utilizados para assegurar direitos e obrigações derivados dessa relação negocial. Discutem-se também as mudanças na legislação desportiva, os pressupostos teóricos que permite verificar se o "jogador de futebol" é um ativo para o clube e aspectos ligados à sua mensuração.

\subsection{História e prática do futebol no Brasil}

A prática do futebol no Brasil, de acordo Santos (2002), começou quando Charles Miller, filho de um engenheiro brasileiro, foi estudar na Inglaterra. Ao conhecer a prática deste esporte denominado "futebol", ficou encantado e trouxe ao Brasil bolas e as regras aprendidas naquele país.

Para alguns, os primeiros vestígios da prática do futebol no Brasil aparecem entre os índios brasileiros que já praticavam atividade semelhante. Há, contudo, os que também afirmam que o futebol teve início com os seminaristas em São Paulo.

De fato, o reconhecimento da prática esportiva no Brasil deu-se mesmo com Charles Miller, em 1894, o qual, até hoje, no meio esportivo, é reconhecido como o precursor desta atividade. Posteriormente surgem as primeiras competições organizadas, iniciando-se, então, um movimento que envolve tanto aspectos sociais, quanto culturais e econômicos.

No que se refere ao aspecto social, relata-se que o esporte era uma prática totalmente elitista, um esporte praticado somente pelas classes altas (maior poder aquisitivo) da época. Devido ao poder de disseminação do futebol, Galeano (1995) observa que “[...] a história do futebol é 
uma triste viagem do prazer ao dever. Ao mesmo tempo em que esporte se tornou indústria, foi desterrando a beleza que nasce da alegria de jogar só pelo prazer de jogar." Ressalta ainda que o futebol reproduz uma paixão tanto de quem assiste quanto de quem o pratica. Historicamente o futebol extrapolou os limites daquele pequeno grupo elitista e foi despontando sua prática nos subúrbios. Aos poucos, os meninos ricos começaram a se misturar aos meninos pobres e os brancos, aos negros e mulatos.

Com a criação dos primeiros clubes pelos operários ingleses que trabalhavam nas construções das estradas de ferro da época, tanto no estado do Rio de Janeiro como no interior do estado de São Paulo, o futebol adquiriu dimensões sociais, econômicas e culturais surpreendentes. É a partir da contextualização histórica que melhor se pode entender e criticar a lógica econômica atual.

Leoncini (2001) relata que os craques que até então eram marginalizados começaram a ser contratados pelos clubes. Os clubes buscavam melhor desempenho nos campeonatos, uma vez que o status de vencedor era algo usado pelos dirigentes em benefício próprio.

Nota-se que a contratação de jogadores como empregados foi uma alternativa encontrada para a solução do impasse, no entanto os dirigentes impunham nos contratos suas vontades. Este fato teve seu panorama modificado somente entre 1950 a 1970, quando os jogadores tiveram a profissão regulamentada na Consolidação das Leis do Trabalho - CLT.

\subsection{O futebol como negócio}

O futebol como negócio é uma atividade econômica vinculada a influências históricas e sociais, contida num sistema composto por instituições e agentes, os quais são resumidos por Leoncini e Silva (1999) em duas vertentes, quanto à prática e ao consumo.

O futebol como prática é representado pelos diversos agentes e instituições ligados direta ou indiretamente à produção de espetáculos futebolísticos: clubes, federações, jogadores, técnicos e demais profissionais de apoio. 
O consumo, no futebol, tem como representantes os consumidores de bens ou serviços, que não atuam na produção do espetáculo, mas participam indiretamente como espectadores "amantes" do futebol, classificados em consumidores diretos e indiretos.

No que diz respeito aos agentes e instituições que participam diretamente do campo do futebol, ao visitar a história, nota-se que o futebol amador era um esporte que tinha características proibitivas, elitistas e racistas - somente a elite o praticava. Entretanto, a prática do futebol nas várzeas se desenvolveu significativamente; é sabido que este esporte é originário das manifestações culturais das camadas populares da Inglaterra do final do século XIX.

Com o passar dos anos apontam-se os seguintes acontecimentos ligados aos agentes diretos clubes da elite e jogadores amadores:

- 1886 - é fundada a Instituição - International Football Association Board, guardiã das regras e da organização desse esporte até hoje;

- 1894 - Charles Miller traz para o Brasil as regras da Inglaterra;

- 1904 - Criação da FIFA (Federação Internacional de Futebol Association), cujas funções principais são organizar e fiscalizar o futebol mundial;

- 1916 - é fundada a CBD (Confederação Brasileira de Desportos);

- 1941 - é fundada a Federação Paulista de Futebol (FPF) no mesmo ano da fundação do Conselho Nacional de Desportos (CND);

- 1980 - é criada a Confederação Brasileira de Futebol (CBF).

Foi nas primeiras décadas do século XX, na cidade de São Paulo, que se estabeleceu pela primeira vez a cobrança de ingressos. Este foi um sinal da transição do esporte amador para o profissional. A era do futebol, então, consolida-se de fato ao profissionalismo, no momento em que os craques que eram marginalizados, surgidos nas várzeas, começaram a ser "contratados" pelos clubes na tentativa de melhorar a performance dentro de campo.

Inicia-se então o fenômeno caracterizado como a vertente do consumo. Conforme descrito por Leoncini (2001), essa vertente é formada pelos agentes consumidores das práticas esportivas 
ou todos aqueles interessados e consumidores do futebol, enquanto consumidores de bens ou serviços ligados aos espetáculos esportivos. São classificados em:

- Consumidor indireto (imprensa escrita, os jornalistas esportivos, o rádio e a TV, e as loterias esportivas);

- Produtores e vendedores de bens (publicidade de material esportivo, licenciamento de produtos, marketing esportivo, consumidor indireto - empresas de todos os tipos e consumidor direto - o torcedor ou amante do futebol).

O interesse destes agentes está diretamente relacionado ao aumento da popularidade do futebol.

\subsection{Aspectos sociais e econômicos do futebol}

Os clubes e ligas de futebol podem ser entendidos como produtores de serviços, a partir da análise de seus principais processos de produção. Os clubes esportivos, atualmente, são entidades que participam cada vez mais da economia mundial. Os esportes passam de uma atividade apenas recreativa e amadora para um negócio que movimenta altas quantias. Entretanto, ainda costumam ser discutidos mais com a emoção e menos com a razão, como é o caso do futebol.

Dadas as características dos clubes recreativos e esportivos, nota-se a necessidade de ferramentas que auxiliem a gestão, devido à dimensão de suas atividades, uma vez que os gestores se deparam com questões como: quem são os clientes dos seus serviços? Quais são os fatores críticos de sucesso? Quais as características do processo de produção?

Este segmento e seus processos, por sua vez, despertam excelentes oportunidades de crítica e inovação em relação aos modelos de gestão. Para entender o processo, Taylor (1998) esclarece que é necessário compreender a estrutura de negócios para os clubes e ligas e entender suas dimensões sociais no relacionamento comercial. 
Observa-se que o futebol é, acima de tudo, um relacionamento em que as partes constituintes de cada nível do "jogo" dependem da existência saudável dos rivais, desde os detentores de direitos de propriedade, administração até as torcidas ativas e o público passivo de TV.

A paixão é o fomento da rivalidade dos torcedores, vista na história do futebol pela ligação do torcedor (fã) ao clube. O valor deste esporte está na força e distribuição de seus clientes. É um mercado cativo que desperta e atrai cada vez mais a mídia (televisão), o qual, pelo poder da torcida, pelo poder da mídia e pelo poder dos jogadores, capitaliza o valor do mercado esportivo.

A ligação do torcedor ao clube é a essência do relacionamento desse negócio, pois é a partir desse relacionamento que surgem todos os outros clientes (TV, patrocinadores etc.).

Para Taylor (1998), os torcedores de futebol são clientes fiéis durante toda a vida. São considerados como uma base de clientes irracionalmente fiéis chamada de "patrimônio de fãs" (recurso natural acumulado ao longo das gerações) e definem o valor base de um clube de futebol no mercado. Porém, o patrimônio de fãs pode ser colocado em risco caso estes percebam a existência de exploração econômica, necessitando-se, para tanto, de sensibilidade para conduzir a "exploração" e manutenção deste recurso.

\subsection{Cadeia de relacionamentos do futebol}

Segundo Gronroos citado por Leoncini (2001), os relacionamentos - tanto entre empresas e clientes, quanto entre empresas e seus próprios empregados - representam a base das empresas de serviços desta nova era pós-industrial. Pode-se descrever a essência dessa sociedade como sendo um "jogo entre pessoas".

Para as empresas, o elemento essencial são os relacionamentos, e no futebol não poderia ser diferente. Na história do futebol, observa-se a existência de duas grandes cadeias de relacionamentos: a primeira refere-se ao segmento produtivo; e a segunda, a uma cadeia de consumo, conforme apresentado na Figura 1. 
C A D E IA P R O D U T IVA

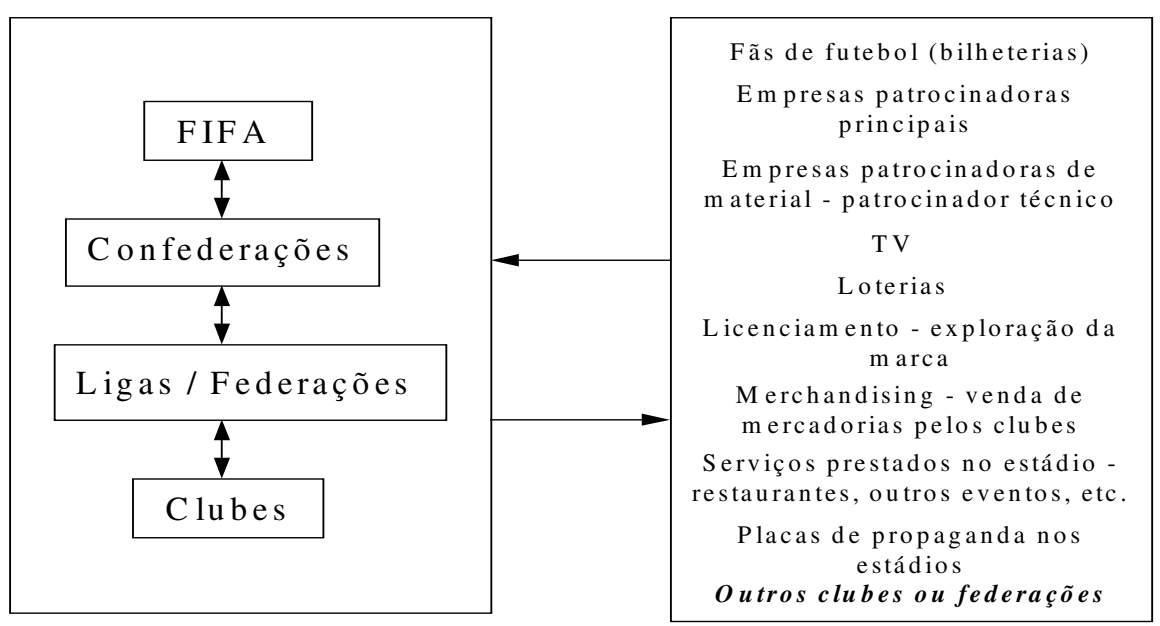

Figura 1 - Cadeias de relacionamento

De forma específica, a cadeia de cliente ou consumo, segundo Leoncini (2001), subdivide-se em relacionamentos provenientes das operações de negócios, subsidiada em sete processos econômicos:

PROCESSO EMPRESARIAL 1 - relacionamento com a TV (direitos de transmissão); PROCESSO EMPRESARIAL 2 - relacionamento com o patrocinador principal (marketing / co-gestão);

PROCESSO EMPRESARIAL 3 - relacionamento com loterias;

PROCESSO EMPRESARIAL 4 - relacionamento com o cliente torcedor / amante do futebol (bilheteria / merchandising);

PROCESSO EMPRESARIAL 5 - relacionamento com o patrocinador técnico (marketing); PROCESSO EMPRESARIAL 6 - relacionamento com empresas produtoras de bens (licenciamento / placas de publicidade);

PROCESSO EMPRESARIAL 7 - relacionamento com outros clubes / federações / empresas patrocinadoras (negociação de jogadores).

Quanto a este processo (7), apesar de fazer parte dos processos de alguns clubes italianos, no Brasil, declaradamente, o presidente da principal associação de clubes - o Clube dos Treze afirma que a negociação de jogadores representa o principal volume financeiro do clube. 
Relativamente ao processo físico-operacional, apresenta a seguinte distribuição por temporada, como uma seqüência de jogos, distribuídos em 86 rodadas para as diversas competições, alocadas em 86 datas no ano de 2003, sendo que:

- o Campeonato Brasileiro consumiu 46 rodadas;

- os Campeonatos Estaduais consumiram 15 rodadas (caso, por exemplo, do Campeonato do Rio de Janeiro);

- a Taça Libertadores da América e a Copa do Brasil, realizadas simultaneamente, consumiram 14 rodadas;

- a Copa Sul-americana (ex-Copa Pan-americana), pela primeira vez disputada por clubes brasileiros, consumiu 10 rodadas (ou mais, é uma decisão que ainda não foi tomada);

- a Taça Toyota, realizada no Japão, consumiu uma rodada, como acontece tradicionalmente.

Este exemplo do calendário esportivo do ano de 2003 demonstra as diversas possibilidades de geração de renda que o futebol brasileiro pode propiciar ao longo de uma temporada.

\subsection{Mercado de jogadores de futebol}

Tanto no Brasil como em países europeus, o segmento esportivo do futebol movimenta bilhões de dólares. As freqüentes transações financeiras com jogadores de futebol representam parte significativa do volume de recursos deste segmento. Além das receitas provenientes das negociações com jogadores, estes influenciam a venda de material esportivo, a publicidade, ou seja, produtos e serviços vinculados à imagem dos atletas.

O mercado futebolístico representa uma parcela economicamente significativa dentro do segmento esportivo, que se encontra dividido em várias atividades22. Diante deste mercado promissor, clubes, empresários e dirigentes buscam investir nesta atividade e realizam cada vez mais investimentos em escolinhas e centros de formação de atletas, com o objetivo de atender a demanda interna e externa dos clubes.

${ }^{22} \mathrm{O}$ termo atividades, neste contexto, refere-se aos processos empresariais ligados ao futebol, conforme apresentado na seção 2.4 . 
O mercado de jogadores caracteriza-se como um mercado onde o "talento" no futebol é negociado "a peso de ouro", um mercado extremamente ativo, do qual clubes sul-americanos desfrutaram por muitos anos. No Brasil, o fim da Lei do Passe trouxe um impacto imediato às finanças dos clubes, deixando-os à beira da falência.

O processo de negociação de jogadores é dinâmico e um dos mais significativos de um clube, pelo fato de a aquisição dos direitos federativos e a formação de jogadores representarem volumes de recursos expressivos, podendo, a venda de um jogador, apresentar um valor superior aos ativos fixos do clube.

Como exemplo, cita-se o caso Ronaldinho, conforme divulgado no IOB - TC (SZUSTER, 2001, p. 5). O passe do jogador foi comprado, em 1992, pelo Cruzeiro de Minas Gerais por US\$ 45 mil e, em sua penúltima transferência, foi vendido pelo Barcelona ao Internazionale de Milão por um valor estimado entre US\$ 28 milhões e US\$ 34 milhões. Desta forma, percebe-se claramente que estes ativos podem ser considerados como elementos que fomentam a atividade econômica dos clubes.

No entanto, após longos e difíceis anos envolvendo negociações de toda a ordem, a FIFA apresentou ao mundo a sua nova regulamentação sobre as transferências internacionais de jogadores de futebol. Modificando e inovando em pontos substanciais o "Regulamento sobre o estatuto e transferência de jogadores", as novas regras vêm, dentre outros fatores, adequar a situação do jogador profissional aos efeitos da famosa sentença Bosman23, proferida pelo Tribunal de Justiça de Luxemburgo.

Todavia, com a prolação da sentença Bosman, em dezembro de 1995, fixou-se um divisor de águas nas relações mantidas entre jogadores e clubes de futebol. Outro fator que influenciou a criação de novas regras foi o crescente número de litígios envolvendo a transferência de jogadores que chegava aos gabinetes da FIFA.

A FIFA propôs então o certificado internacional de transferência de jogador. Sempre que um jogador se transfere de um clube pertencente a determinado país a outro de país diverso, faz-

\footnotetext{
${ }^{23}$ Bosman foi o primeiro jogador a conseguir passe livre.
} 
se imprescindível a expedição do certificado internacional de transferência para que tenha condições de atuar, sendo que tal documento deve ser obrigatoriamente expedido pela associação nacional do antigo clube do atleta a pedido da associação nacional do novo clube.

Ao contrário do que acontecia antigamente, as transferências internacionais de jogadores e a conseqüente emissão dos certificados terão validade se forem requisitadas dentro do período estabelecido para a inscrição de novos jogadores pela associação nacional requerente, limitando-se consideravelmente as transferências.

No Brasil não existe (ou existia) um período limítrofe para a contratação de jogadores advindos de clubes estrangeiros (o que não se confunde com os prazos para inscrição de novos jogadores em campeonatos em andamento), sendo que, a qualquer época do ano, era lícita a sua contratação e a conseqüente requisição do certificado internacional de transferência.

\subsection{O fim de um "Impasse"}

Há algum tempo, jogadores de futebol do mundo inteiro buscam o fim do passe24, e os registros datam o caso Bosman como o precursor da extinção do passe. Entretanto, a situação do passe foi substituída, após o caso Bosman, por um contrato que mantém vinculado o jogador a um clube por um período de tempo. Este tipo de contrato utiliza-se de mecanismos como multas rescisórias, a fim de manter o jogador ligado ao clube. Deste modo, o jogador só pode mover-se para outro clube, sem taxa de transferência, após o fim do contrato, exceto em caso de reembolso.

No Brasil, este direito extinguiu-se com o advento da Lei Pelé no 9.615 de 24.03.1998, com a qual a relação entre os jogadores de futebol alterou-se de forma substancial, surgindo, em seguida, a Medida Provisória 79 que trouxe uma nova regulamentação para o setor, extinguindo o passe, contudo a relação comercial fica regida por contratos de prestação de serviços, com cláusulas específicas de ressarcimento pelo rompimento.

\footnotetext{
${ }^{24}$ PASSE: Dentro do cenário do futebol representa um direito que o clube possui sobre o atleta, o qual mantém o atleta preso ao clube, uma vez que o clube negocia este direito como um ativo.
} 
Os atletas têm vínculos com os clubes por prazos determinados até 23 anos de idade, e o primeiro contrato do atleta como profissional tem duração de 2 anos. Decorrido este prazo contratual e na eventualidade de o clube formador não ter interesse na sua renovação, o atleta poderá vincular-se a qualquer outro clube sem impedimento, entretanto a primeira renovação tem um prazo estipulado de três meses a cinco anos.

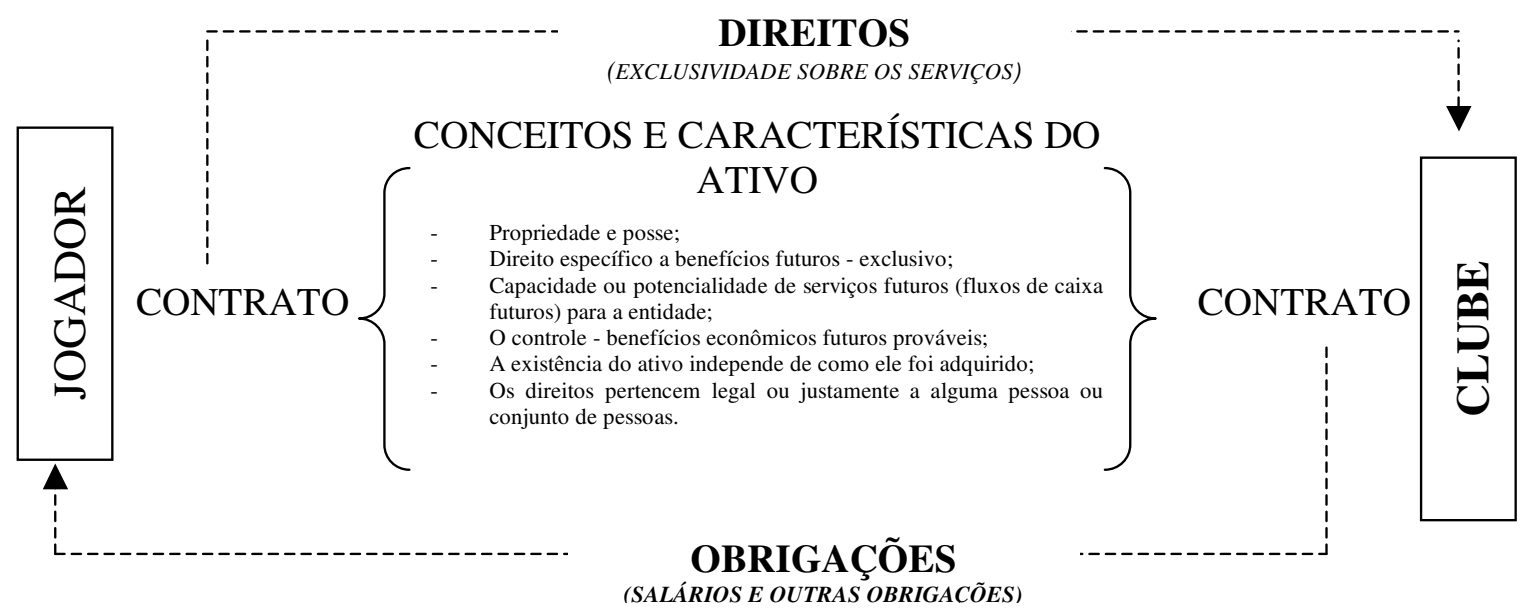

Figura 2 - Relação contratual entre jogador e clube

Conforme demonstrado na Figura 2, o contrato torna-se um instrumento que cria direitos e obrigações entre o jogador e o clube. Anteriormente à Lei Pelé, existia o passe, o que garantia aos clubes direitos sobre os jogadores, permitindo aos clubes negociar este direito, no entanto observa-se que o fim do passe trouxe uma mudança apenas do passe para o contrato com multa rescisória.

\subsection{Contratos - medida de segurança de clubes e jogadores}

A formalização dos negócios no mercado do futebol é realizada por intermédio de contrato entre as partes interessadas, os contratos de patrocínio, exploração de direitos de imagem, aquisição de atletas, empréstimo e venda de atletas.

Ferreira $(1988$, p.125) define contrato como o "[...] acordo entre duas ou mais pessoas que entre si transferem direito ou se sujeitam a uma obrigação." O contrato tem como uma das 
suas prerrogativas a regulamentação de direitos e deveres entre as partes, além de assegurar o compromisso entre elas.

No Brasil, no que diz respeito à relação entre atleta e clube, existe uma regulamentação específica que determina prazos, prioridades de renovação e multas pela rescisão de contratos entre clube e atletas contratados, emprestados ou formados pelas categorias de base do clube.

Com o fim do "passe", proposto pela Lei Pelé, houve uma redução significativa no volume de receitas oriundas das negociações com atletas. Os chamados "direitos liberatórios" eliminam a figura do "passe" e dão maior liberdade ao jogador para negociar o contrato. O caso Bosman foi precursor do fim do passe, que foi substituído por um contrato que mantém vinculado o jogador a um clube esportivo por um período de tempo, no qual se utilizam mecanismos como multas rescisórias para manter o jogador no clube. Deste modo, o jogador só poderá ser transferido para outro clube sem multa após o fim do contrato com o clube ao qual está vinculado.

Fernandes (2002, p.2) aborda que,

[...] a exemplo disto na Inglaterra, a Premier League vai além, padronizou todos os contratos de jogadores em formações com regras claras de responsabilidade e funções de cada um, seja o clube, a federação e o país do atleta, existe até um limite geográfico para buscar novos talentos, claro que os grandes clubes burlam essa regra e trazem toda a família do jovem talento para seu alcance.

Fernandes (2002) comenta que grande parte disso não é novidade no Brasil. Alguns clubes já aplicam essa filosofia na formação de seus talentos, embora as autoridades que regulamentam o futebol brasileiro ainda não tenham padronizado os contratos. A Confederação Brasileira de Futebol e outros órgãos competentes que poderiam fomentar essa padronização para identificar o clube formador, delegar responsabilidades no processo e saber quem de fato é o dono do passe desse novo talento, ainda não fizeram isto, verificando-se, assim, que se trata de uma questão que ainda não está bem resolvida para o futebol brasileiro.

A constituição do contrato e a renegociação de contratos podem acontecer em diversas fases na carreira do atleta, sendo que cada contrato é um evento, é uma decisão e o gestor deveria avaliar o seu impacto econômico. 
Sunder (1997) descreve que a contabilidade possui cinco funções em relação à coordenação aos diversos contratos existentes entre os agentes e empresa:

- mensurar a contribuição de cada um dos participantes nos contratos;

- mensurar a fatia que cada um dos participantes tem direito do resultado da empresa;

- informar aos participantes a respeito do grau de sucesso no cumprimento dos contratos;

- distribuir informação para todos os potenciais participantes em contratos com a empresa para manter a liquidez de seus fatores de produção; e

- distribuir algumas informações como conhecimento comum para reduzir o custo da negociação dos contratos.

Hendriksen (1999, p.142-143) explica que "A linguagem utilizada na contabilidade positiva é baseada em contratos e acordos. Supõe-se que investidores, consumidores, administradores, funcionários e outros indivíduos fazem contratos explícitos e implícitos uns com os outros".

O contrato pode ser entendido como instrumento de conciliação de interesses e conflitos tanto presentes como futuros. Sob esta ótica, as entidades esportivas empregam este instrumento para administrar e conciliar os conflitos de interesses inerentes a suas atividades, interesses tais como: direito de imagem, patrocínios, publicidade e até a negociação de atletas.

Caracterizam-se, os contratos, como acordos interindividuais que podem ser bilaterais ou com mais de duas partes, segundo Siffert Filho (1996), sob uma economia na qual pré-existe uma distribuição particular de recursos raros. Pensa-se em uma economia na qual os agentes são obrigados a compartilhar recursos específicos (isto é, dificilmente reproduzíveis) e complementares (certos recursos devem ser associados com outros para produzirem utilidade).

O contrato é o momento no qual se estabelecem os pesos e as medidas na materialização dos desejos entre as partes e, assim, permite o acesso a recursos e ao seu uso. Nesta mesma linha, o contrato entre clube - jogador tem como finalidade garantir o acesso aos recursos e ao seu uso. 
Ainda segundo Siffert Filho (1996), os contratos não são necessariamente escritos, documentos jurídicos. A noção abrange os acordos interindividuais, quer sejam escritos ou não, explícitos ou implícitos.

Williamson (1985) citado por Siffert Filho (1996, p. 38) afirma que

[...] a essência de todas as instituições "sócias"- a Firma, mais ainda o Estado, a Tribo, a Família etc. - podem ser compreendidas a partir dos "contratos". Enfim, vários autores consideram que as conclusões das teorias dos contratos contribuem para explicar os mecanismos de regulação social: a lei, a moeda, as convenções sociais etc.

Observa que os "contratos informais" constituem uma experiência, um costume do homem originado pela descendência, por seus usos e costumes. Destarte, os contratos informais ou formais tornam-se de fato uma medida de conciliação e harmonização das relações sociais, culturais, políticas e econômicas de uma comunidade organizada.

Siffert Filho (1996, p.38) afirma que, se na maior parte dos casos os contratos mais comuns referem-se aos contratos entre indivíduos, é comum que os ensinamentos da teoria se apliquem a todos os contratos entre os grupos, coalizões e organizações, os quais são considerados como entidades que constituem, de direito ou de fato, "pessoas morais", uma vez que são unidades de decisão autônoma no espaço econômico.

A teoria dos contratos tem como função elaborar uma matriz de análise das relações econômicas, com o objetivo de explicar as estruturas econômicas.

A teoria da agência, formulada inicialmente por Ross (1973) citado por Siffert Filho (1996), é uma relação comum no contexto econômico, pois a relação de agência existe desde que haja uma relação de garantia, uma relação de débito e crédito ou relação de delegação na qual um mandante confia a um mandatário (delegado) a realização de uma tarefa por responsabilidade do primeiro. No futebol, a relação de agência pode ser vista na Figura 3, em que aparecem tais enfoques; tem-se então: o principal (clube) e o agente (jogador). 


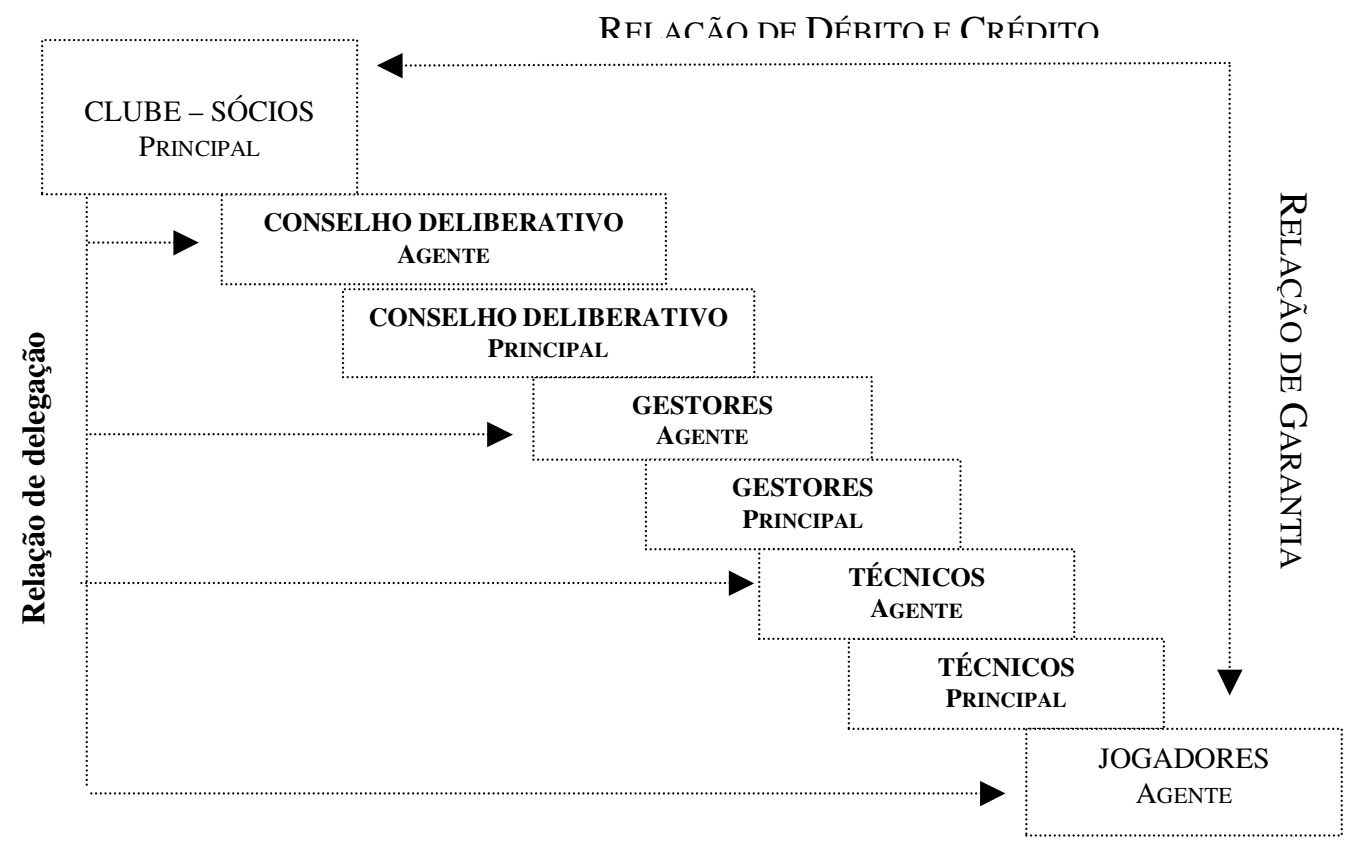

Figura 3 - Cadeia agente-principal - clube de futebol

FONTE: Adaptado de SLOMSKI; 2001b

A Figura 3 demonstra três relações:

- Relação de garantia: o contrato firmado entre clube - jogador garante exclusividade sobre os serviços do jogador, por tempo determinado, ao clube. Em contrapartida, existe a garantia ao jogador de salários e gratificações pelo tempo acordado.

- Relação de débito e crédito: o Principal: o clube - direito - jogador - obrigação com clube (direito de exclusividade por um tempo determinado sobre os serviços); Agente: o jogador - direito - clube - obrigação com jogador (uma obrigação de remuneração por tempo determinado pelos serviços que serão prestados).

- Relação de delegação: o clube delega ao jogador o papel de representar sua marca nas atividades esportivas do futebol.

Tem-se em vista que a relação entre clube - jogadores é regida por um contrato que estabelece direitos e obrigações, sendo, o contrato, a alternativa para administrar os interesses e conflitos dos acordos entre principal - agente. 


\subsection{O Direito de Imagem - uma fonte de renda para os clubes}

Dentre as fontes de renda do futebol, a exploração do direito de imagem é uma fonte considerada rentável para os clubes e os atletas. Antes de dar início aos limites de utilização da imagem do cidadão, faz-se necessário esclarecer o termo "direito de imagem".

Para Redig apud Castro (2002), imagem é “[...] todo o tipo de representação da pessoa, ou seja, uma pintura artística, uma escultura, um desenho ou uma fotografia. E compreende não só a pessoa inteira, mas as diferentes partes do seu corpo." Assim, é claro que qualquer pessoa, independentemente da idade, famosa ou não, que jogue futebol ou não, possui o direito à sua imagem, comumente chamado Direito de Imagem.

Entende-se que o direito de imagem é uma subespécie de um outro direito maior, o Direito Autoral, e faz parte dos direitos da personalidade. Sendo um direito da personalidade, possui algumas características próprias, quais sejam, é: indisponível; irrenunciável; e imprescritível.

Segundo Castro (2002), o direito de imagem surge quando do nascimento com vida da pessoa, porém não acaba quando a pessoa morre.

Este direito, em sua essência, somente pode ser cedido e jamais pode ser vendido, doado, emprestado e nem se pode abrir mão dele. Por conseqüência, ninguém pode comprar, alugar ou adquirir definitivamente esse direito.

No futebol, quando os atletas assinam um contrato de imagem com o clube, ocorre a chamada cessão do direito de imagem, ou seja, o atleta autoriza o clube a explorar a sua imagem, mas o dono da imagem continua sendo o atleta e jamais o clube. Desta forma, é necessário que, no contrato de licença de uso de imagem, o sujeito de direito autorize a utilização comercial de sua imagem, por um determinado período e sob certas condições. Essa autorização pode ser gratuita ou remunerada.

Castro (2002) afirma que os clubes e atletas firmam contratos de cessão de direito de imagem por vários motivos: 
- Pagamento de menores encargos trabalhistas e impostos (tanto por parte do jogador como por parte do clube, o benefício é recíproco e não é só do clube);

- Possibilidade de exploração por meio de fotos de um ídolo fazendo dessa exploração uma fonte de receita para o clube, como álbuns de figurinhas, entre outros.

Este tipo de negócio torna-se extremamente necessário para o clube, pois, se a entidade esportiva não possuir tal contrato com o atleta, não poderá comercializar nenhum produto que tenha ou use a imagem dele.

O valor atribuído à compra do direito de exploração de imagem de um atleta profissional é algo que depende de diversas variáveis. Castro (2002) aborda que, quanto mais famoso e carismático for o atleta, maior deverá ser a quantia por este recebida. Em muitos casos o valor pago pela exploração do direito de imagem pode ser superior ao salário pago pelo clube.

\subsection{Os jogadores como ativos do clube de futebol}

Tendo em vista a existência de um mercado ativo para negociação de jogadores de futebol, dada sua relevância para o patrimônio da entidade, faz-se necessário discutir, à luz da teoria, estes elementos ligados ao futebol.

\subsubsection{Conceitos de ativos}

Para D’Auria apud Iudícibus (1993, p.94), ativo “[...] é, finalmente, o conjunto de meios ou matéria posta à disposição do administrador para que este possa operar de modo a conseguir os fins que a entidade entregue à sua direção tem em vista.” Na opinião de Iudícibus (1993), esta visão de ativo é restrita, uma vez que o conjunto de meios ou matéria posta à disposição pode encaminhar a um entendimento apenas dos elementos de natureza tangível, acarretando a exclusão dos elementos intangíveis como, por exemplo, o Goodwill.

Por outro lado, Martins (1972, p.33) ressalta que itens como patentes, licenças, especiais, direitos autorais e outros intangíveis também são considerados ativos pela definição. E tanto eles como todos os demais assim o são, não pela incorrência por parte da firma em qualquer custo para a sua obtenção, mas pela sua natureza de agentes de futuros resultados econômicos. 
Finalmente, também se enquadram todos os recursos humanos, quer os dirigidos para a administração, quer os para a produção de bens ou serviços. Dessa forma, espera-se desses recursos um resultado econômico no futuro. Sendo estes recursos econômicos merecedores de reconhecimento como ativos contábeis, deste modo compreende-se que o conceito de ativo é muito mais amplo.

Para Paton apud Iudícibus (1993, p.94), “[...] ativo é qualquer contraprestação, material ou não, possuída por uma empresa específica e que tenha valor para aquela empresa." No entanto, Iudícibus considera esta definição de 1924 de Paton um mérito, pois realça os aspectos materiais ou não dos ativos, e salienta que o ativo precisa ter valor para empresa, não sendo suficiente que tenha apenas um valor de troca, o que deixa implícita a noção de utilidade do ativo para a empresa.

Canning apud Hendriksen e Van Breda (1999, p. 283-284) considera-o como "[...] qualquer serviço futuro, em termos monetários, ou qualquer serviço futuro conversível em moeda [...] cujos direitos pertencem legal ou justamente a alguma pessoa ou conjunto de pessoas. Tal serviço é um ativo somente para essa pessoa ou esse grupo de pessoas que o usufrui."

Segundo Sprouse e Moonitz apud Martins (1972, p. 28), os ativos são definidos da seguinte forma: "Assets represent expected future economic benefits, rights have been acquired by the enterprise as a result of some current or past transaction.” Martins (1972) comenta essa visão, demonstrando que a existência ou expectativa de futuros resultados econômicos é o cerne do conceito de ativo.

Dentro de uma visão pragmática, o FASB25 definiu ativos, no SFAC 6, como: "Benefícios econômicos futuros prováveis, obtidos ou controlados por uma dada entidade em conseqüência de transações ou eventos passados."

Em Hendriksen e Van Breda (1999, p. 284), o pronunciamento no 4 do APB26 definiu ativos do seguinte modo: recursos econômicos medidos em conformidade com princípios

${ }^{25}$ In: Hendriksen e Van Breda (1999) - FASB Financial Accountancy Standard Board, comitê americano de regulamentação das normas contábeis.

${ }^{26}$ In: Hendriksen e Van Breda (1999, p. 61-62) - APB - Accounting Principles Board - Conselho de Princípios Contábeis, criado em 1959 em substituição ao CAP - Committe on Accounting Procedure de 1936, face ao 
geralmente aceitos incluindo certas despesas diferidas que não representam recursos. Ao comentar estas definições, Hendriksen e Van Breda destacam que o APB tem caráter interpretativo, enquanto o FASB reflete a sua preocupação com a utilidade da divulgação da informação, num sentido pragmático.

De acordo com Iudícibus (1993, p. 106),

[...] o ativo, sua conceitualização e avaliação configuram-se talvez como o capítulo mais importante da teoria contábil, ao lado do capítulo de receitas, despesas, perdas e ganhos. É extremamente relevante conceituar bem o ativo, em suas características básicas, para evitarmos problemas futuros com a apreciação desse ou daquele elemento específico do ativo, desse ou daquele grupo. Muitos problemas na prática contábil brasileira derivam de aceitarmos sem discussão classificações legais, sem termos atentado para significado intrínseco de cada ativo.

Pacheco (1996, p. 16) ressalta que todo ativo, seja um imobilizado seja um direito a receber, um pagamento já realizado, ou um gasto ativado para amortização futura, tem características gerais comuns, independentemente de seu tipo específico. A característica fundamental é sua capacidade de prestar serviços futuros à entidade que os tem como propriedade, individual ou em conjunto com outros ativos e fatores de produção, capazes de se transformar, direta ou indiretamente, em fluxos líquidos de entradas de caixa.

\subsubsection{Características dos ativos}

Diante do exposto pode-se notar que as definições apresentam peculiaridades, Iudícibus et al. (2000, p. 130) apontam três aspectos a serem observados na definição de ativos:

1. Ativo deve ser considerado à luz de sua propriedade e/ou à luz de sua posse e controle; normalmente as duas condições virão juntas;

2. Precisa estar incluído no ativo, em seu bojo, algum direito específico a benefícios futuros (por exemplo, a proteção à cobertura de sinistro, como direito em contraprestação ao prêmio de seguro pago pela empresa) ou, em sentido mais amplo, o elemento precisa apresentar uma potencialidade de serviços futuros (fluxos de caixa futuros) para a entidade;

3. O direito precisa ser exclusivo da entidade; por exemplo, o direito de transportar a mercadoria da entidade por uma via expressa, embora benéfico, não é ativo, pois é geral, não sendo exclusivo da entidade.

Outro ponto que deve ser ressaltado é a relação da existência de um ativo para a entidade. $\mathrm{Na}$ opinião de Sprouse e Moonitz apud Martins (1972, p. 27), a existência de um ativo independe de como ele foi adquirido - "[...] the existence of an asset is independent of the means by was

crescimento de investidores que desejavam uniformidade nas demonstrações financeiras para permitir comparações e decisões. 
acquired." Para Martins (1972), esta afirmação categoricamente repele aquela limitação e abre um novo campo, dando uma dimensão mais realista ao próprio balanço.

Contudo, Hendriksen e Van Breda (1999, p. 285) afirmam que o controle é abordado como característica essencial, no qual um ativo possui três características essenciais, sendo uma delas o controle; uma entidade pode conseguir o benefício e controlar o acesso de outras entidades a esse benefício. Entretanto, para Martins (1972, p.27), quanto à idéia de controle, entende que a conceituação da palavra "controle" é bastante ampla.

Para Hendriksen e Van Breda (1999, p. 285), outra característica do ativo apontada refere-se à incorporação de um benefício futuro provável que envolva a capacidade, isoladamente ou em combinação com outros ativos, de contribuir direta ou indiretamente à geração de entradas líquidas de caixas futuras.

A respeito dos ativos do futebol, pode-se compartilhar da relação entre o ativo e seu agente, onde o ativo humano é o jogador e o clube é o agente que usufruirá dos seus benefícios, à medida em que pode trazer resultados econômicos futuros para a entidade. No entanto, o valor dos benefícios econômicos futuros gerados pelo jogador de futebol pode ser comparado com o que é destacado por Martins (1972, p. 30) ao afirmar:

[...] é necessário frisar que um balanço procura representar no ativo. Os itens que representam valores econômicos para a entidade a que se refere. Isso quer dizer simplesmente que o aparecimento de um elemento no ativo de uma empresa não significa econômico para qualquer outra. Onde o Resultado econômico deve estar relacionado a uma entidade especificamente, já que o uso público ou o favorecimento a muitos faz com que o recurso deixe de ter a caracterização como ativo, em muitas circunstâncias. A firma pode usufruir da existência das ruas da cidade, o que, porém, não lhe dá o direito de colocá-las como ativo seu.

Segundo Iudícibus e Marion (2001, p.33), funcionários de uma empresa não são contabilizados como ativo, pois, ainda que sejam um bem, não são propriedade da entidade. $\mathrm{Na}$ época dos escravos, todavia, as fazendas os contabilizavam como ativo, pois eram propriedades da empresa. Atualmente, o jogador de futebol é considerado um ativo, pois o clube tem a posse sobre o passe, o que se extingue com o passe-livre. No entanto, mesmo com o fim do passe, se o jogador permanecer no clube, compreende-se que ele irá proporcionar benefícios à entidade; o contrato torna-se instrumento que assegura ao clube a possibilidade de reconhecer o fluxo de benefícios esperados. Deve-se ressaltar que o jogador atende às características de ativos demonstradas abaixo: 
- Propriedade e posse; normalmente as duas condições virão juntas; o ativo precisa, em seu cerne, incluir algum direito específico a benefícios futuros, ou seja, precisa apresentar uma potencialidade de serviços futuros (fluxos de caixa futuros) para a entidade; o direito precisa ser exclusivo da entidade (IUDÍCIBUS, 1993);

- A existência de um ativo independe de como ele foi adquirido (SPROUSE; MOONITZ apud MARTINS, 1972);

- O controle é característica essencial, ou seja, a entidade pode conseguir o benefício e controlar o acesso de outras entidades a esse benefício; outra característica do ativo apontada refere-se à incorporação de um benefício futuro provável que envolva a capacidade, isoladamente ou em combinação com outros ativos, de contribuir direta ou indiretamente à geração de entradas líquidas de caixas futuras (HENDRIKSEN; VAN BREDA, 1999);

- Benefícios econômicos futuros prováveis, obtidos ou controlados em conseqüência de transações ou eventos passados (FASB - SFAC 6 apud HENDRIKSEN; VAN BREDA, 1999);

- Recursos econômicos medidos em conformidade com princípios geralmente aceitos (APB apud HENDRIKSEN; VAN BREDA, 1999);

- Ativo é qualquer contraprestação, material ou não, possuída por uma empresa que tenha valor para aquela empresa (PATON apud IUDÍCIBUS, 1993);

- Qualquer serviço futuro, em termos monetários, ou qualquer serviço futuro conversível em moeda cujos direitos pertencem legal ou justamente a alguma pessoa ou conjunto de pessoas (CANNING apud IUDÍCIBUS, 1993);

- Resultado econômico deve estar relacionado a uma entidade especificamente (MARTINS, 1972).

\subsection{Ativos humanos}

A partir do século XX, o mundo sofre mudanças que desafiam as ciências sociais, em especial a contabilidade. Para Antunes e Martins (2002, p.42), esse período de gradativas mudanças na economia mundial vem sendo apontado por estudiosos como período de transição de uma sociedade industrial para uma sociedade do conhecimento, visto que, aos demais recursos existentes e até então valorizados e utilizados na produção - terra, capital e trabalho, se junta 
o conhecimento, que altera, principalmente, a estrutura econômica das nações e a forma de valorizar o ser humano.

O interesse pela contabilidade de recursos humanos teve início em meados dos anos sessenta com pesquisas que propunham estudar e desenvolver modelos para avaliação de recursos humanos, na tentativa de montar um sistema de contabilidade para esta área empresarial, tendo este movimento sido empreendido até 1970.

Após a década de setenta, a pesquisa em contabilidade de recursos humanos torna-se apática. Sua retomada deu-se em 1980, nos E.U.A., com o pesquisador Flamholtz (1976, 1985). Tempos depois, o interesse pelo assunto é percebido pelos suecos, especificamente nos anos noventa por Grojer e Johanson (1998, p.495-505). Recentemente houve interesse da União Européia e da Organização para Cooperação Econômica e Desenvolvimento pela administração de recursos humanos, no qual se identifiquem os ativos intangíveis, ao considerar que estes elementos são importantes para a competitividade nacional e conseqüentemente para análise adicional e investigação.

Ativos humanos e recursos humanos são interpretados como sendo elementos essenciais para a entidade. Na visão de Flamholtz apud Pacheco (1996, p.49), “[...] o critério essencial para determinar se um gasto é um ativo ou despesa relaciona-se à noção de potencial de serviços futuros"; nota-se que o potencial de serviços futuros, ou seja, a geração de benefícios econômicos futuros o caracteriza como um ativo.

Martins (1972, p.32) define que os ativos humanos são considerados como agente, neste caso, engloba o mesmo significado que recursos para a economia. Não se restringe apenas a valores de existência física ou monetária.

Como Lipsey e Steiner apud Martins (1972, p.32) mencionam,

[...] (the resources) consist not only of the free gifts of nature, such as land, forests, and minerals, but also of human resources, both mental and physical, and of all sorts of man-made aids to further production, such as tools, machinery and buildings.

Martins (1972, p.33) menciona que os ativos humanos são considerados ativos pela definição. E tanto eles como todos os demais o são, não pela incorrência por parte da firma em qualquer 
custo para a sua obtenção, mas pela sua natureza de agentes de futuros resultados econômicos. Sendo os recursos humanos dirigidos para a administração ou para a produção de bens ou serviços, são recursos dos quais se espera um resultado econômico no futuro, representam itens do ativo da entidade a que se referem. São recursos econômicos e, portanto, merecedores de reconhecimento como ativos contábeis. Outros itens são abrangidos como ativos, sendo impossível discriminá-los um a um. O importante aqui é firmar nossa posição do que se entende como ativo sob o ponto de vista contábil, não devendo haver divórcio com o que se entende como ativo.

Para Antunes (1999, p. 47), os ativos humanos são uma parte do capital intelectual. Assim, deve-se considerar tais aspectos e efeitos decorrentes da existência dos elementos que compõem o capital intelectual como os fatores endógenos às empresas, que influenciam seu valor de mercado e capacidade que os elementos componentes possuem de gerar lucros futuros. A nova realidade demonstra que esses elementos agregam valor às empresas, e a contabilidade deve considerar tais ativos intangíveis e desenvolver uma forma para evidenciálos. Portanto, fica claro que a mensuração das transações envolvendo o patrimônio de uma entidade, cuja função pertence à contabilidade, é demasiadamente complexa.

Para Brooking apud Antunes e Martins (2002, p.12-13), o conceito de ativos humanos encontra-se dentro do conceito de capital intelectual, o qual se divide em quatro categorias:

ATIVOS DE MERCADOS: potencial que a empresa possui em decorrência dos intangíveis que estão relacionados ao mercado, tais como: marca, patentes, lealdade dos clientes, negócios recorrentes, negócios em andamentos (backlog), canais de distribuição, franquias etc.

ATIVOS DE PROPRIEDADE INTELECTUAL: Incluem os ativos que necessitam de proteção legal para proporcionar às organizações benefícios tais como: know-how, segredos industriais, copyright, patentes, designs etc.

ATIVOS DE INFRA-ESTRUTURA: compreendem as tecnologias e os processos empregados, como cultura, sistema de informação, métodos gerenciais, aceitação de risco, banco de dados de clientes etc.

ATIVOS HUMANOS: compreendem os benefícios que um indivíduo pode proporcionar para as organizações por meio de suas atividades, expertise, criatividade, conhecimento, habilidade para resolver problemas, tudo visto de forma coletiva e dinâmica.

Já Edvinsson e Malone (1998, p.9) empregam uma linguagem metafórica para melhor conceituar o capital intelectual. Comparando a empresa a uma árvore, consideram a parte visível - tronco, galhos e folhas - como o que está descrito em organograma, nas demonstrações contábeis e em documentos; e a parte que se encontra abaixo da superfície - as raízes -, ao capital intelectual, o qual subdivide em duas categorias: 
CAPITAL HUMANO: composto pelos equipamentos, expertise, poder de inovação e habilidades dos empregados mais os valores, a cultura e a filosofia da empresa;

CAPITAL ESTRUTURAL: formado pelos equipamentos de informática, softwares, banco de dados, patentes, marcas registradas, relacionamento com os clientes e tudo o mais da capacidade organizacional que apóia a produtividade dos empregados.

Dentre as abordagens sobre ativos humanos, observa que os autores divergem sobre o conceito, pois alguns definem que ativo humano é uma extensão do capital intelectual, outros abordam que ativos humanos representam os recursos humanos que uma entidade possui e que irão produzir algum resultado futuro, além da abordagem de capital humano. A exemplo disso:

- Martins (1972) - ativo humano representa os recursos humanos dirigidos para a administração ou para a produção de bens ou serviços, são recursos dos quais se espera um resultado econômico no futuro, representam itens do ativo da entidade a que se referem.

- Flamholtz (1976) - ativos humanos e recursos humanos são interpretados como sendo um dos elementos essenciais para a entidade.

- Brooking (apud Antunes; Martins, 2002) - os ativos humanos encontram-se dentro do conceito de capital intelectual, o qual se divide em quatro categorias, sendo que os ativos humanos compreendem os benefícios que um indivíduo pode proporcionar para as organizações por meio de suas atividades, expertise, criatividade, conhecimento, habilidade para resolver problemas, tudo visto de forma coletiva e dinâmica.

- Edvinsson e Malone (1998) - trata estes elementos como capital humano, o qual é composto pelos equipamentos, expertise, poder de inovação e habilidades dos empregados mais os valores, a cultura e a filosofia da empresa.

- Antunes (1999) - corrobora o conceito de Brooking de que os ativos humanos são uma parte do capital intelectual.

Diante das abordagens conclui-se que não existe consenso sobre o conceito de ativo humano, mas, de um modo geral, identifica-se que as definições levam em consideração a capacidade do elemento humano de gerar benefícios à entidade. 


\subsubsection{Jogador - ativo do futebol}

As entidades esportivas possuem uma gama de ativos, tais como nas empresas públicas e privadas, na qual se encontram ativos humanos (capital intelectual) para gerir suas atividades, dentro de um segmento específico da economia.

Szuster (2001, p.4) afirma que a maioria das grandes empresas possui ativos físicos como prédios, fábricas, estoques, e ativos humanos, como nas empresas de auditoria e de publicidade. As organizações esportivas são diferentes, além de algumas edificações e ativos financeiros e operacionais, prédios de escritório e alguns administradores, seus ativos são simbólicos e intangíveis. Portanto, a atividade esportiva, especificamente, tem uma movimentação significativa quanto às receitas geradas com as transações realizadas com o valor do passe do jogador ou atestado liberatório.

As entidades esportivas podem, então, classificar os atletas como ativos? Diante de tal indagação, o usuário da informação deve refletir sobre a necessidade de reconhecer e avaliar estes elementos como ativos humanos. Tal reconhecimento e avaliação estão marcados pelo alto grau de subjetividade. Logo, pergunta-se sobre a necessidade de evidenciar a depreciação e os fundos de pensão, visto que estes apresentam estimativas e possuem alto grau de subjetividade. No entanto, são evidenciados nas demonstrações financeiras, oferecendo informações ao processo decisório.

Pelo simples fato da geração de benefícios econômicos futuros para entidades esportivas, acredita-se que deveriam se classificar como ativos e também por apresentarem semelhança aos ativos das entidades tradicionais, no entanto os ativos humanos poderiam ser classificados de forma diferenciada, uma vez que a contabilidade tradicional não registra ativos humanos como itens patrimoniais.

Quanto aos recursos humanos, surge a necessidade de evidenciar os reflexos destes ativos na geração de recursos econômicos para a entidade. Entretanto, a mensuração deste capital humano ou ativos humanos demonstra um novo desafio para a contabilidade, que busca sair do foco da mensuração voltada ao custo, voltando-se para o valor.

Iudícibus (2001) retrata bem este período de evolução da contabilidade, o qual apresenta, como item mais importante na discussão, o fato de o Contador ter coragem para atribuir e 
mensurar os elementos do ativo, passivo e Patrimônio Líquido - PL, bem como os fluxos de renda e de caixa. Isto leva a críticas por não agradar aos tradicionalistas e aos que desejariam que o balanço retratasse o valor da entidade na data. Portanto, quanto mais evoluímos em nossa ciência, mais nos afastamos do custo e mais nos aproximamos do valor, sem, provavelmente, alcançá-lo.

Os clubes esportivos fazem altos investimentos, tanto na formação quanto na aquisição de direitos sobre os serviços de atletas; tais valores pagos chegam a superar o valor patrimonial (ativos permanentes) da entidade. A título de exemplo, o caso do jogador brasileiro Ronaldinho retrata esse volume financeiro transacionado no mundo dos negócios esportivos. Tais transações representam as principais fontes geradoras de riqueza dos clubes brasileiros. Atualmente como, para vincular ao clube os jogadores, constitui-se contrato que mantém o atleta vinculado ao clube por tempo determinado, o registro contábil tradicional deve considerar todos os gastos necessários para que um atleta possa atuar pelo clube.

O valor total investido em cada atleta deve ser controlado através do critério da identificação específica e a amortização deste ativo deve considerar a sua utilização. Deve-se considerar também que estes ativos podem gerar outras formas de rendimentos, seja através de multas rescisórias previstas nos contratos ou negociação para liberação dos passes de forma temporária (empréstimo) ou definitiva (venda).

Szuster (2001, p. 12) relata a importância da Lei 9615/97, conhecida como Lei Pelé, e regulamentada pelo Decreto $\mathrm{n}^{\circ} 2.574$, de 29 de abril de 1998, o qual tem como principais pontos o fim do passe dos jogadores em três anos a partir da vigência da lei, possibilitando, mas não havendo obrigatoriedade, de os clubes (ou seus departamentos de esporte profissional) transformarem-se em empresas; independência da justiça desportiva; maior tributação dos bingos; criação das ligas regionais e nacionais independentes, com autonomia para organizar competições esportivas; e criação de uma sociedade independente para os árbitros.

Inicia-se, então, um movimento que visa proporcionar as novas informações exigidas a respeito dos recursos físicos, monetários e intelectuais, quanto ao patrimônio, a renda, a prestação de contas, atribuindo responsabilidade cível e penal a: dirigentes, administradores, gerentes, contadores e demais pessoas envolvidas na atividade. Trata-se de um movimento 
que procura dar à atividade esportiva as mesmas (status) normas e regras das empresas privadas. Dessa forma, entende-se que a contabilidade é um instrumento que poderá proporcionar o início de uma nova era para a gestão dos clubes de futebol no Brasil.

Como na atividade esportiva os jogadores são os maiores ativos dos clubes de futebol, estes são considerados os workforce 27 , que participam da geração de riqueza. Um exemplo semelhante pode ser notado nos casos das empresas onde os gerentes são considerados como maior ativo de uma entidade.

Neste contexto, os funcionários certamente geram benefícios econômicos futuros para a entidade, mas esta não possui o direito legal para retê-los e registrá-los nas demonstrações financeiras, porque o funcionário pode entregar a qualquer momento sua carta de demissão. Assim, a entidade tem controle insuficiente sobre os benefícios futuros esperados do empregado, deste modo não se recomenda reconhecê-lo como ativo. Entretanto, no futebol, o contrato garante um tratamento contábil diferenciado, ao possibilitar o reconhecimento, a mensuração, a avaliação e a evidenciação nas demonstrações financeiras.

A partir do momento que o capital intelectual começa a dividir o foco de atenção que era dado somente ao capital físico (bens corpóreos ou tangíveis), nota-se uma tentativa de medir e avaliar o capital intangível das empresas, marcas, patentes, fundo de comércio, Goodwill e capital intelectual. Neste momento, cabe aos profissionais de contabilidade determinar métricas que permitam a quantificação do conhecimento, o que se torna um desafio presente.

Nesta linha de raciocínio, Iudícibus (1993, p. 22) declara que,

Num mundo econômico com freqüentes alterações de cenário, é importante entender bem o que é teoria, bem como vários enfoques e metodologias, a fim de os contadores poderem dar respostas ou interpretações satisfatórias para uma série de novos eventos e fenômenos que estão a desafiar nossa profissão.

Antunes (1999, p.3) afirma que “[...] o conhecimento é mais valioso do que os recursos naturais $[. .$.$] por possuírem algo mais valioso do que os ativos físicos ou financeiros, ou seja,$ por possuírem capital intelectual." Mais especificamente, no mundo dos esportes e, da mesma forma, pode-se fazer uma analogia ao talento do jogador em vez do conhecimento.

\footnotetext{
${ }^{27}$ Considerada força de trabalho.
} 
Diante deste contexto, o grande desafio da contabilidade é mensurar os benefícios econômicos gerados pelo jogador de futebol, tendo em vista o potencial de exploração do clube em relação ao jogador.

\subsection{Conceitos de mensuração}

$\mathrm{Na}$ busca de medir ou atribuir valor a este impasse, descreve-se a seguir o conceito de mensuração como o ato de medir, e medir por sua vez significa, segundo Ferreira (1988, p. 428), “[...] determinar ou verificar, tendo por base uma escala fixa, a extensão, medida ou grandeza de; comensurar." Observa-se que esta definição considera um parâmetro de referência; deve-se ter por base uma escala fixa, ou seja, a atribuição de números com posição definida numa escala.

Chambers (1974, p. 74) explica que "A mensuração é a designação de números a objetos ou eventos mediante regras que especifiquem a propriedade a ser medida, mediante escala ou padrão a usar, e dimensões da unidade de medida." Com a definição anterior denotam-se três aspectos importantes: o objeto - o que medir; o padrão - relaciona-se com a escala a ser usada; e a dimensão - relaciona-se com a unidade que deve ser usada.

Nelo (1996, p. 56-69) afirma que, para medir uma extensão, o parâmetro de referência é o metro; para medir a terra o parâmetro é o hectare; para medir o patrimônio tem-se como parâmetro a moeda. A moeda é um parâmetro que por si só possui suas próprias restrições. Sobre isto se referiu anteriormente que a escala deve ser fixa e a moeda perde o valor em função das variações ocorridas num determinado período de tempo.

Deste modo, ao utilizar a moeda como parâmetro de referência para avaliação das informações contábeis, recorre-se à correção monetária para que essas informações sejam expressas em moeda de poder aquisitivo constante na data em que as referidas informações são elaboradas, a fim de obter o subsídio necessário para realização de predições e tomar decisões.

Para Kam (1986, p. 84), 
[...] nós queremos mensurar é a característica do valor de cada ativo e passivo. Mas, qual é o número? Há um número de valores monetários dos quais nós temos conhecimento: custo de aquisição, custo de reposição, preço de saída, valor realizável líquido, valor presente etc. O que nós necessitamos é do valor que melhor informe aos usuários a respeito da firma. Este valor constitui informações úteis para os investidores.

Percebe-se que o ato de mensurar pode ser visto sob diversas óticas, o que o diferencia é a finalidade e utilidade da informação requerida, pois existem diversos critérios, entretanto o método ideal será aquele que atribuirá valor e que fornecerá informações úteis ao momento decisório.

De acordo com Nelo (1996, p. 56 -58),

A mensuração contábil é o processo de atribuir valores às transações ou eventos, de modo que eles sejam ordenados sistematicamente, objetivando fornecer informações relativas ao patrimônio. Assim, podemos dizer que a mensuração contábil está ligada ao processo de atribuir valor aos ativos, passivos e patrimônio líquido, viabilizando avaliação financeira passada, presente e permitindo fazer projeções futuras.

Essa mensuração é resumida nas demonstrações financeiras, assim as demonstrações dos clubes de futebol devem refletir as mudanças da posição financeira no período de tempo mensurado.

A contabilidade, como mecanismo de mensuração, procura fornecer informações financeiras, dá ênfase à atribuição de valores monetários aos bens, direitos e obrigações, e oferece aos usuários, "clientes, torcedores, sócios, governo”, os resultados. Deste modo, verifica-se que os contadores se envolvem emocionalmente com os critérios de mensuração, ao dar opiniões, interpretam de acordo com suas tendências pessoais. Esses processos de mensuração passam pelos processos mentais das pessoas que operam, que elaboram o modelo, ou que testam um critério já existente.

Os fatores ou variáveis que ocorrem no ambiente em que a empresa está inserida são independentes da vontade do observador, e devem ser selecionados por ele, assim como os fatores que irão fazer parte do modelo de mensuração. 
Nos parágrafos anteriores foi demonstrado que uma diferença de interpretação tem, como conseqüência, resultados diferentes. Portanto, é necessário verificar quais fatores devem ser considerados na escolha de um critério de mensuração.

Ao escolher um critério de mensuração ou elaborar um modelo de mensuração, Ijiri (1967, p. 135) considera que "[...] três fatores devem ser considerados no modelo de mensuração: o objeto a ser mensurado; o critério de mensuração adotado; o grupo de mensuradores."

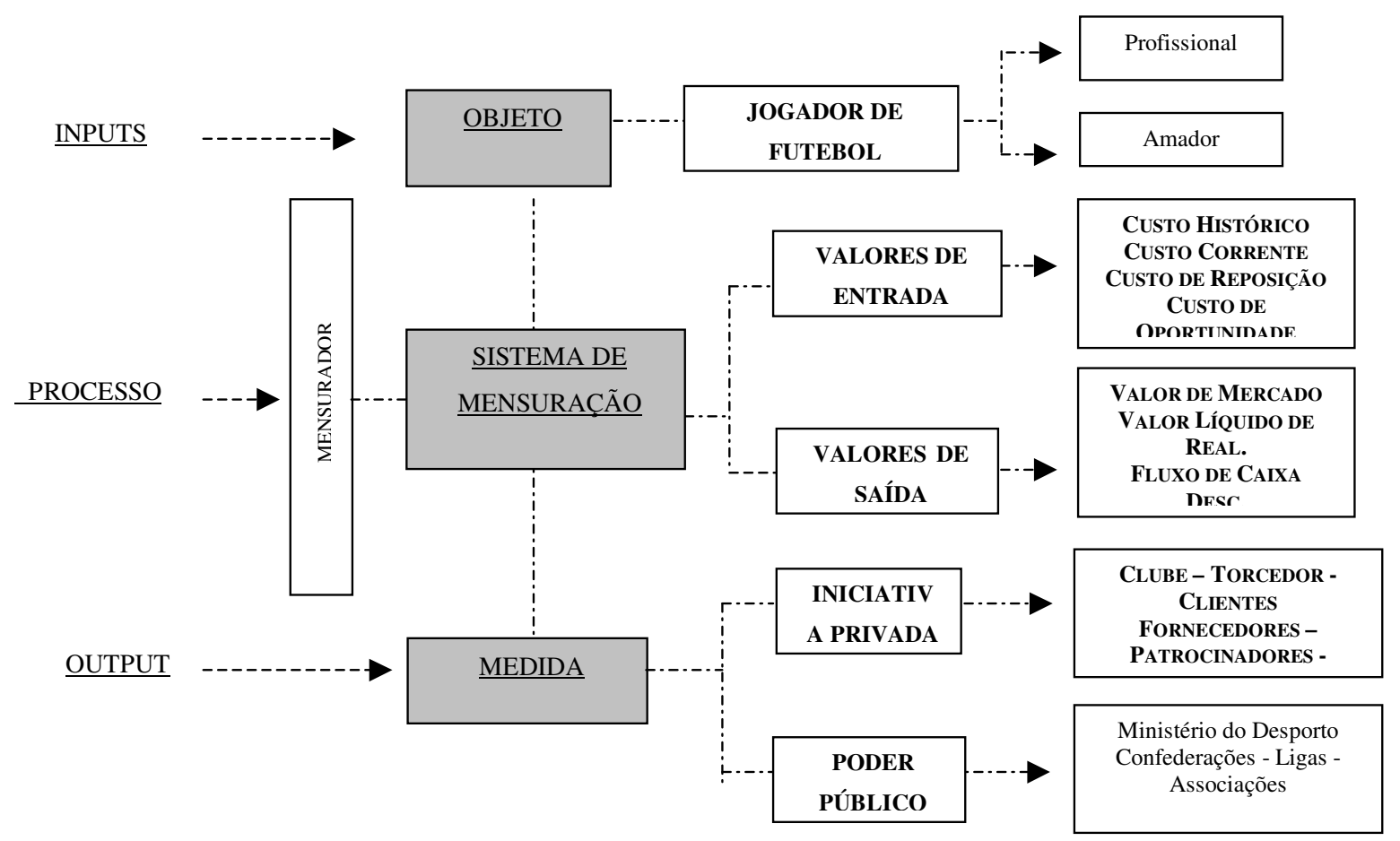

Figura 4 - Modelo de mensuração no segmento esportivo

FONTE: Elaborado com base no modelo de IJIRI, 1967, p. 135

O objeto de mensuração contábil é o patrimônio. Mas, com relação ao critério de mensuração escolhido, deve ser observado o conjunto de regras que orientam e dão sustentação ao referido critério. Se essas regras forem bem definidas, exigirão menos esforço; caso contrário, exigirão mais interpretações por parte dos mensuradores e, conseqüentemente, poderão variar mais entre os mensuradores. 


\subsubsection{Etapas do processo de mensuração}

A atribuição de valor a objeto, coisa e eventos torna-se uma missão cada vez mais complexa, o que caracteriza um grande desafio à ciência contábil, visto que a mensuração das informações contábeis possui uma série de restrições, principalmente nos âmbitos legal e fiscal.

Em condições de incertezas, tem-se a restrição do conservadorismo. Conforme ressaltado por Iudícibus et al. (1982, p. 98), encontram-se “[...] conjuntos alternativos de avaliação patrimonial para o patrimônio igualmente válidos, segundo os princípios de contabilidade, a contabilidade escolherá o que apresentar o menor valor atual para o ativo e o maior para as obrigações", sendo que o contador é o responsável pela materialidade da informação que esta repassa aos usuários internos e externos, assim este deve conhecer as limitações dos critérios de avaliação contábil.

A mensuração das informações contábeis está relacionada com o valor a ser atribuído ao ativo, passivo e patrimônio líquido, mas existem diversas alternativas para avaliação, as quais podem ser compartilhadas na mensuração e avaliação dos ativos.

Kircher apud Rocha et al. (1994, p. 24) descreve as seguintes etapas do processo de mensuração para a tomada de decisão:

1) Objetivo da mensuração: deve-se estabelecer qual o objetivo, ou seja, para que se está mensurando;

2) Determinação dos fatores relevantes: neste passo deve-se estabelecer quais os fatores que poderiam atender os objetivos estabelecidos. Como, por exemplo, se o objetivo é atravessar um rio e se deseja mensurar os custos para atender este empreendimento, os fatores que podem atender este objetivo seriam alternativas como atravessar de barco, de avião, de trem se houver uma ponte, entre outros.

3) Seleção dos aspectos-chaves: além de se determinar quais os fatores que poderiam atingir o objetivo, deve-se obter os aspectos-chaves envolvidos na mensuração. Esses aspectos são os dados quantitativos relacionados aos fatores relevantes, os quais serão usados no processo de mensuração e, ainda, os qualitativos, os quais poderão alterar itens quantitativos, selecionados.

4) Seleção do método e unidade: este passo está voltado à seleção do melhor procedimento e cálculos necessários para levar a cabo o processo de mensuração, bem como a unidade que será utilizada para expressar as características do objeto mensurado. É imprescindível que a unidade adotada seja inteligível à luz de quem se utilizará do resultado da mensuração.

5) Aplicação da unidade de mensuração: trata-se do processo de mensuração efetivo. É o foco central de todos os procedimentos. Quando as características são obtidas através dos cálculos expressos com base numa unidade escolhida.

6) Análise da mensuração: a mensuração deve ser testada e aplicada a outras mensurações. Os resultados não podem ser distorcidos nem, tampouco, variáveis em função de local, tempo, entre outros. O produto deste passo é a construção de um modelo de mensuração que poderá ser aplicado em qualquer outra hipótese posterior, da mesma natureza de mensuração; 
7) Avaliação/interpretação do resultado: neste último passo devem ser avaliados os resultados obtidos, se foram interpretados corretamente, se o número que resultou do processo de mensuração efetivamente diz respeito às características do objeto mensurado.

\subsubsection{A objetividade da mensuração contábil}

Segundo Littleton e Paton apud Ijiri (1967, p.133), “[...] a evidência objetiva tornou-se um elemento importante em contabilidade e um auxílio necessário para execução da função contábil a fim de fornecer informações mais confiáveis." Assim, subentende-se que a evidência, nesse caso, está relacionada com a verificabilidade da própria mensuração.

É comum que a objetividade, por ser própria da mensuração contábil, apresente um certo atrativo, porém é difícil definir o que é ou não objetivo, podendo, em determinados casos, levar ao desacordo. De acordo com Fertig apud Ijiri (1967, p. 134), “[...] a importância da objetividade (isto é, ausência de viés) na mensuração contábil é facilmente estabelecida [...] As demonstrações contábeis só são úteis até o ponto no qual sua objetividade possa ser demonstrada pela satisfação do usuário.” Seguindo essa linha de raciocínio, percebe-se claramente a relação entre a objetividade e a utilidade da informação.

Segundo Ijiri (1967, p. 134), “Apesar da concordância comum de que a objetividade seja importante como critério, há uma surpreendente falta de concordância sobre o que o conceito deveria significar e como deveria ser aplicado." Portanto, se o critério ou modelo de mensuração é útil para os usuários realizarem predições e tomarem decisões, as discussões referentes ao critério tornar-se-ão desnecessárias.

Hendriksen (1982, p. 73) considera

[...] quatro significados para a objetividade da mensuração contábil: $1^{\circ}$ ) mensurações são impessoais ou existem fora da mente da pessoa que as faz; $2^{\circ}$ ) a mensuração é baseada em evidências verificáveis; $3^{\circ}$ ) mensurações são baseadas em consenso de especialistas qualificados; $4^{\circ}$ ) há dispersão estatística da mensuração de um atributo quando feito por mensuradores diferentes.

Nota-se que as definições anteriores confirmam que a mensuração é impessoal ou que existe como algo fora da mente das pessoas que a realizam. Mas, ao escolher um critério de mensuração de ativos, o contador já está assumindo um posicionamento e as próprias regras que envolvem o modelo escolhido são processadas na mente de quem as escolheu. 


\subsubsection{A atribuição de valor ao jogador e a relação com o clube}

Mensuração ou atribuição de valor aos jogadores, tanto profissionais como amadores, pode estar relacionada ao ambiente onde ele se encontra inserido. Para entender este contexto, Nelo (1996, p. 56-69) retrata valor subjetivo da seguinte forma,

[...] uma simples ilustração a respeito do valor seria útil: que valor tem para determinado indivíduo o fato de cursar uma faculdade e qual o custo do curso? O custo da educação é o sacrifício econômico que fez durante os anos de faculdade, enquanto o valor está relacionado com os benefícios futuros.

O processo de atribuir valor, como acima mencionado, é subjetivo. Segundo Barbieri et al. apud Nelo (1996, p. 56-69),

[...] o simbolismo contábil que integra as mensurações de ativos, passivos, receitas e despesas implicitamente possui as características de avaliação. E o valor de um bem, para um indivíduo, pode ser maior que o seu valor de troca por várias razões: por questões de estima, por necessidade, por escassez, por simbologias culturais, religiosas, etc.

Ao analisar a mensuração como o processo de atribuir valores à riqueza e às suas mutações patrimoniais, torna-se necessário analisar a objetividade e confiabilidade da mensuração. A título de exemplo pode-se relacionar a questão de identificação do valor de um atleta: o jogador "Marcelinho Carioca" teria o mesmo valor para a torcida do Palmeiras e para os torcedores do Corínthians?

Para Hendriksen (1982, p. 75), a mensuração contábil tradicionalmente significa uma relação de valores numéricos para objetos e eventos relacionados à empresa obtidos de tal modo que são convenientemente agregados (tal como a avaliação do ativo total) ou desagregação como solicitada por uma situação específica.

Dentro desta abordagem, nota-se que a avaliação econômica de um jogador de futebol pode ser considerada muito mais complexa do que se pensa, uma vez que a mensuração e a avaliação destes ativos devem analisar: o cenário onde o jogador atua; antecedentes históricos; idade; afinidade e carisma com os torcedores; como o clube pretende explorar o uso do direito de imagem. Portanto, busca evidenciar a capacidade de geração de benefícios econômicos futuros ou fluxo de caixa. 


\subsubsection{O processo de mensuração do jogador de futebol}

A partir do pressuposto de que os jogadores de futebol atendem aos conceitos de ativos e seu valor pode ser mesurado, então quais critérios poderiam ser utilizados para atribuir ou medir o valor deles?

Segundo Michie e Verma (1999, p. 5), se os jogadores de futebol podem ser contabilizados nas demonstrações, então sugerem duas aproximações amplas para avaliar os empregados, na literatura: uma alternativa fundamentada na teoria dos métodos custo: custo histórico, custo de reposição, custo de oportunidade, e outra pelos métodos de valor de mercado: valor econômico dos recursos. No entanto, ressaltam que ambos os métodos possuem vantagens e limitações, e em ambos os critérios existe subjetividade. Portanto, estas avaliações sempre apresentam certo grau de subjetividade no processo de avaliação destes ativos. Porém, o tratamento contábil dado aos jogadores de futebol é menos complexo que o de outros empregados de uma empresa, pois existe um mercado de transferência ativo para jogadores de futebol que são negociados regularmente. Assim, os clubes de futebol podem contabilizar os seus jogadores adquiridos ao custo de aquisição que é a taxa de transferência paga pelo clube.

Esta atividade tem como base de sustentação dois pilares associados à compra e venda de atletas, existindo duas situações distintas que devem ser analisadas: a primeira, referente a atletas já formados pelos clubes que atuam como profissionais e já foram validados pelo mercado, e a segunda que se refere aos atletas em formação, ou seja, refere-se ao como lidar com jogadores que não são adquiridos, mas formados pelas categorias de base dos clubes.

Atualmente, alguns clubes utilizam os custos e despesas gastas com os atletas, isto é, o problema com a utilização do método de custo histórico reside em identificar e contabilizar todos os custos relacionados para treinar e desenvolver tais jogadores. Mesmo com a identificação precisa dos custos de treinamento e desenvolvimento do atleta, estes não refletiram o verdadeiro valor do jogador.

O método de avaliação utilizado para jogadores de futebol formados pelas categorias de base dos clubes, segundo Michie e Verma (1999, p. 7), seria contabilizar tais jogadores ao valor de reposição, ou seja, equivale a contabilizar a quantia necessária para a substituição daquele jogador no mercado livre. Identificar o custo de reposição do jogador também envolve uma 
avaliação subjetiva, uma vez que o custo de reposição atual só pode ser determinado objetivamente quando o jogador é substituído de fato.

Este método apresenta subjetividade, como qualquer outro método de avaliação de jogadores, mas, apesar disto, provê informações úteis. Independente do método escolhido para avaliar os jogadores, é necessário utilizar um sistema de estimação para determinar o valor dos atletas, no entanto recomenda-se desenvolver o método de acordo com as características da indústria do futebol.

Michie e Verma (1999, p. 5) propõem duas alternativas como os sistemas mais apropriados e precisos para avaliar os jogadores dentro da indústria de futebol: cada clube faria a avaliação dos seus próprios jogadores, por meio de uma equipe ou comissão interna especialmente designada, como utilizado por clubes como o Manchester United no passado. Outra alternativa seria designar uma comissão independente de peritos para ajudar a estipular valores aos jogadores dos clubes ou só revisar estimações propostas pelos clubes de futebol para assegurar que elas sejam razoáveis.

Esta metodologia já é empregada por clubes europeus, nos quais uma comissão de arbitragem fixa taxas de transferência para o jogador, quando os clubes não puderem chegar a acordo. Seria possível estender o papel desta comissão de arbitragem para lidar com estimações de jogador em uma base regular.

Outro ponto que desperta polêmica refere-se à amortização dos jogadores de futebol, uma vez que são contabilizados. Quando um jogador de futebol é adquirido por um clube, existe um custo (taxa de transferência, multas rescisórias ou direito federativo); da mesma forma, quando se adquirem outros ativos fixos, o valor desse desembolso com o jogador poderia ser contabilizado ao seu custo para o clube, e amortizado sistematicamente em cima da sua vida econômica útil. Para que esta metodologia seja aplicada, deve-se calcular a vida econômica útil de cada jogador; através da estimativa não seria difícil determinar a vida econômica útil, assim como em outros ativos fixos. Portanto, pode-se amortizar o valor da taxa de transferência embasada na vida útil dos jogadores.

Devido às mudanças sobre a questão do passe, o jogador pode deixar o clube no vencimento do contrato, sem a obrigação de reembolso. Entretanto, se o jogador escolher renovar seu 
contrato, ele poderá ser reavaliado na hora da renovação e a reavaliação seria amortizada, então, sobre o novo período do contrato.

Os jogadores representam valores expressivos, e certos ativos humanos de clubes e entidades esportivas podem ser contabilizados e avaliados como ativos e divulgados nas demonstrações contábeis. Uma consequiência direta da identificação desses ativos é a explicação parcial do porquê da existência de diferença entre o valor econômico do patrimônio líquido da instituição e seu respectivo valor contábil.

No entanto, a não aceitação e classificação destes elementos, pela contabilidade financeira, de vários itens como componentes do ativo pode-se justificar, em virtude, principalmente, dos princípios do custo como base de valor e o da confrontação das despesas com as receitas, mais as convenções da objetividade e do conservadorismo.

Os ativos humanos são agentes das empresas, que representam uma parte significativa na geração de fluxos futuros de benefícios econômicos. Assim sendo, este trabalho procurou demonstrar como estes ativos podem influenciar a geração de riqueza para a entidade e contou com a realização de uma pesquisa que retratou os aspectos de mensuração de ativos humanos aplicados aos clubes desportivos brasileiros. O trabalho relatou ainda que o setor (segmento) movimenta um volume significativo em transações financeiras e requer estudos sobre avaliação econômica destes ativos.

Dessa forma, a pesquisa contábil deverá proporcionar uma simetria informacional ao usuário, na qual este seja capaz de proceder à devida avaliação sobre a realidade econômica e financeira da entidade (uma avaliação que espelhe o verdadeiro valor entidade), tornando possível inferir sobre as tendências futuras, aproximação de novos investidores, e maior desenvolvimento e administração dos recursos.

Os usuários desta subárea da contabilidade (contabilidade desportiva) podem ser representados por: sócios dos clubes que contribuem para o financiamento das contas e querem preservar a continuidade do clube; torcedores que colaboram com a renda dos jogos ou com a compra de produtos; atletas e empresários que se interessam pela saúde financeira dos clubes; e investidores que aportam recursos. 


\section{A METODOLOGIA DE ESTUDO DE CASO}

Tendo em vista que, à luz da teoria contábil, o jogador de futebol pode ser caracterizado como um ativo para o clube, busca-se agora investigar em campo quais as decisões e eventos ligados à gestão deste e as respectivas variáveis que impactam a sua avaliação. De forma específica, este capítulo tem como objetivo apontar os meios e os instrumentos utilizados para obtenção dos dados da pesquisa.

\subsection{Conceitos e definições}

A realização de um estudo de caso, segundo Yin (2001, p. 78), “[...] começa com a definição dos problemas ou temas a serem investigados e o desenvolvimento de um projeto de estudo de caso."

À medida que o pesquisador realiza um trabalho de estudo de campo, deve constantemente se perguntar por que os eventos ocorreram ou estão ocorrendo. Além disto, deverá perceber que a pesquisa baseia-se em perguntas e não necessariamente em respostas, deste modo uma resposta deveria levar o pesquisador a uma quantidade enorme de novas questões. Yin (2001) classifica estes procedimentos como um exercício a ser realizado durante todo o trabalho, pois estas atitudes caracterizam um bom entrevistador.

Somado a isto, o pesquisador deverá ter como objetivo a clareza das questões originais que estão sendo estudadas, de maneira que existam compreensão e coerência na investigação do início ao fim.

\subsubsection{Questões de pesquisa}

Toda pesquisa de um modo geral baseia-se em questões a serem investigadas. Portanto, estas devem estar claras, senão pistas importantes poderão se perder, e o pesquisador poderá não conseguir identificar possíveis mudanças de curso do estudo. 
Outra questão chave refere-se à coleta de dados do estudo de caso, pois esse estudo não trata apenas de registrar mecanicamente os dados, mas trata também da interpretação das informações e distinção das diversas fontes, de possíveis contradições e, ainda, se existe ou não necessidade de fontes adicionais, de maneira que as inferências sejam baseadas em evidências convergentes, provenientes de fatos, para que, assim, o estudo atinja efetivamente os objetivos propostos.

\subsubsection{Instrumento de coleta de dados}

A pesquisa de campo buscou respostas à questão (ver Anexo A) junto aos gestores do clube, através de entrevistas, análise de documentos e observação. Estes instrumentos de coleta de dados, para Lakatos e Marconi (2003, p.208-209), podem ser em forma de:

- $\quad$ questões de fato: questões concretas, tangíveis, fáceis de precisar;

- $\quad$ questões de ação: as quais se referem a atitudes ou decisões tomadas;

- $\quad$ questões sobre a intenção: tentam averiguar o procedimento do indivíduo em determinar situações;

- $\quad$ questões de opinião: identificam a opinião do sujeito da pesquisa.

\subsubsection{Estratégias de pesquisas}

As estratégias de pesquisas são imprescindíveis ao processo de pesquisa, pois delas dependem todo desenvolvimento e os resultados, ou seja, é neste momento que o pesquisador terá de usar as habilidades que lhe são inerentes para obter o maior número possível de evidências sobre o objeto pesquisado. Somente assim o estudo poderá oferecer um entendimento dos fenômenos, das variáveis e de suas relações.

Yin (2001, p.129) aponta que:

[...] o pesquisador do estudo de caso deve possuir uma versatilidade metodológica que não é necessariamente exigida em outras estratégias e deve obedecer a certos procedimentos formais para garantir o controle de qualidade durante o processo de coleta. [...] de forma que os resultados finais - os dados que foram coletados - reflitam uma preocupação pela validade do construto e pela confiabilidade, o que, dessa forma, validaria a realização de análises adicionais. 
Para a realização deste estudo, fundamentou-se nas contribuições de Yin (2001) acima referidas.

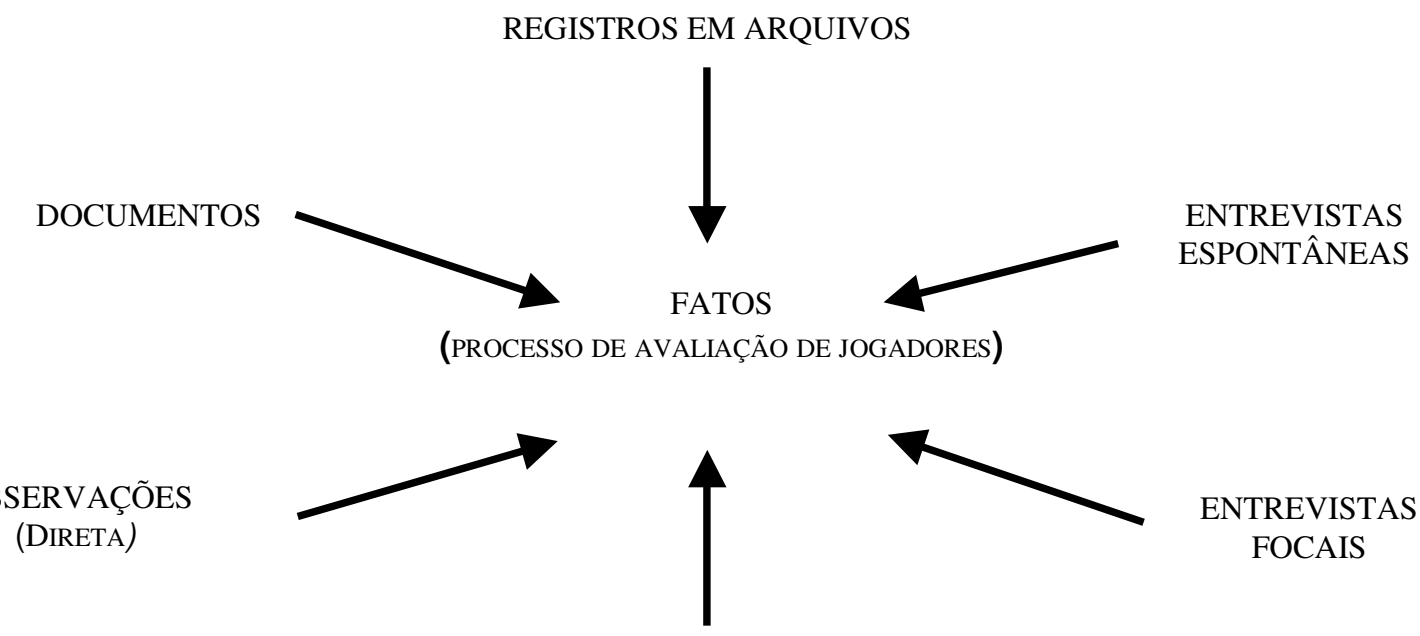

$$
\begin{aligned}
& \text { ENTREVISTA E } \\
& \text { LEVANTAMENTOS } \\
& \text { ESTRUTURADOS }
\end{aligned}
$$

Figura 5 - Convergências de várias fontes de evidências (estudo único)

FONTE: adaptado de Cosmos Corporation apud YIN; 2001, p. 122

Dentre as estratégias apontadas:

O REGISTRO EM ARQUIVO é um tipo de fonte que permite armazenagem de informações em conjunto com outras fontes, geralmente em sua forma computadorizada, tais como: registro de serviços, registros organizacionais, mapas e tabelas, dados oriundos de levantamentos e registros pessoais.

Para o estudo de caso aqui proposto, foram utilizados os registros que se referem a documentos que apontam informações econômicas, financeiras e esportivas do clube pesquisado, como: contratos; folha de pagamentos; demonstrações financeiras; apontamentos e planilhas de custos por áreas, atividades e por atletas. 
No tocante às informações operacionais esportivas, foram colhidos dados e documentos que resguardam informações esportivas específicas do processo operacional (treinamento e formação de atletas), tais como:

$\checkmark \quad$ Estatísticas dos jogos;

$\checkmark \quad$ Estatísticas de jogadores;

$\checkmark \quad$ Fichas de desempenho dos atletas.

Além dos DOCUMENTOS averiguados, constatou-se que o clube adota uma metodologia específica para avaliação e desenvolvimento de atletas das respectivas categorias de base: infantil, juvenil e juniores.

Esta metodologia, além de subsidiar a formação de atletas, oferece assistência aos atletas que compõem a equipe profissional. Yin (2001) relata que, quando se julga que as provas são importantes, o pesquisador deverá averiguar sob quais condições elas foram produzidas e qual o seu grau de precisão.

Outra estratégia utilizada foi a técnica de ENTREVISTAS que se caracterizam como uma das fontes mais importantes para um estudo de caso. Yin (2001) considera-as essenciais, pois permitem fazer associações usuais entre as entrevistas realizadas e o método de levantamento de dados. As entrevistas podem ser classificadas como: espontâneas, focais e estruturadas.

As fontes mais usadas foram as ENTREVISTAS ESPONTÂNEAS. Para Yin (2001), esta técnica permite que o pesquisador tanto indague o respondente sobre os fatos quanto peça sua opinião sobre determinados eventos, permitindo ainda que os entrevistados ofereçam suas próprias interpretações de certos acontecimentos. Deste modo, torna-se viabilizada a utilização das proposições extraídas de uma entrevista para novas pesquisas.

As ENTREVISTAS FOCAIS têm um objetivo mais específico. Nestas, o respondente é entrevistado por um curto período de tempo - uma hora, e as questões, na maioria das vezes, originam-se do protocolo do estudo de caso.

Yin (2001) aponta que este tipo de entrevista tem como propósito corroborar certos fatos que o pesquisador acredita já terem sido estabelecidos. Entretanto alerta que as questões devem 
ser cuidadosamente formuladas, para que o entrevistado não se sinta influenciado pelos juízos de valor do entrevistador, permitindo-se, deste modo, que o respondente faça novos comentários. Além disso, o pesquisador deve estar atento às respostas do entrevistado para que não haja um desvio do foco central do estudo.

Outra fonte é a ENTREVISTA E LEVANTAMENTOS ESTRUTURADOS, caracterizados por Yin (2001) como um tipo de entrevista mais organizada sob forma de levantamentos, permitindo que as respostas possam ser comparadas para conferir sua consistência.

Todavia, o pesquisador deve estar atento, pois o local do estudo de caso pode oferecer algumas interpretações sobre os processos causais, enquanto que o local onde se realizaram os levantamentos pode oferecer alguma indicação da predominância do fenômeno.

Algumas vantagens são apontadas para utilização desta técnica, como a possibilidade de classificações paralelas, a comparação dos resultados e das evidências descobertas, e ainda permite constatações de padrões consistentes, a fim de se determinar o grau de convergência das fontes dos dados.

De modo geral, as entrevistas constituem uma fonte essencial para apontar evidências para a pesquisa. Recomenda-se que estas informações sejam registradas e interpretadas sob os olhos do pesquisador.

Contudo, Yin (2001) relata que as entrevistas devem ser vistas como fontes verbais que estão sujeitas a alguns problemas como: preconceito, memória fraca e articulação pobre ou imprecisa. No entanto, estes pontos deficitários não invalidam a sua aplicação, desde que os devidos cuidados sejam tomados, entre eles o registro das entrevistas através de gravadores. Este meio fornece uma expressão mais acurada do que qualquer outro método.

A OBSERVAÇÃO consiste em uma técnica que cria oportunidades ao pesquisador sobre o objeto estudado, das variáveis e de seus impactos, por meio de observações dos processos. Além disso, possibilita a captura de provas úteis que forneçam as evidências necessárias às questões propostas. 
Yin (2001) descreve que a OBSERVAÇÃO DIRETA se caracteriza pela visita do pesquisador ao local escolhido para efetuar o estudo, possibilitando-lhe observar os fenômenos de interesse não puramente de caráter histórico, e que estão disponíveis à observação de comportamentos e aspectos ambientais relevantes.

Esta técnica oferece provas observáveis que são úteis para obtenção de informações adicionais sobre o objeto estudado. Através deste método, o pesquisador pode compreender os limites e os problemas dos processos de avaliação, bem como da implementação de uma nova tecnologia ligada à avaliação esportiva.

Yin (2001) afirma que tirar fotos do ambiente pesquisado pode se caracterizar como uma estratégia valiosa, ajuda a transmitir as características importantes do caso estudado a observadores externos. Outro aspecto importante que aumenta a confiabilidade das evidências observacionais é ter mais de um observador fazendo observação - tanto de caráter formal quanto informal.

Esta técnica tem como finalidade a observação dos processos físico-operacionais esportivos, bem como do processo de gestão do respectivo clube, e dos parâmetros utilizados na negociação de jogadores de futebol. Uma vez selecionados os métodos / técnicas de coletas de dados, torna-se imprescindível a elaboração dos protocolos de pesquisa.

\subsubsection{Protocolos de pesquisa}

Esta fase é denominada como protocolo de pesquisa e tem como objetivo orientar a busca de evidências e procedimentos. De modo específico, demonstra como transcorreu o estudo. Desta forma, Yin (2001, p. 89) afirma que “[...] o protocolo é uma das táticas principais para aumentar a confiabilidade da pesquisa de estudo de caso e destina-se a orientar o pesquisador ao conduzir o estudo de caso."

Devido à importância do protocolo de pesquisa, elaborou-se um protocolo que norteou os levantamentos empíricos, que transcorreram da seguinte forma: documentação, observações, entrevistas, registro de arquivos, visita ao processo físico-operacional e análises de documentos, transcorridos nas seguintes etapas: 
$1^{\text {a }}$ Etapa - Contato com o Clube Atlético Paranaense - mês de janeiro de 2003.

Objetivo: verificar a possibilidade de realizar o estudo (observação e sondagem).

$2^{\text {a }}$. Etapa - Entrevista com o superintendente de futebol - mês de agosto 2003.

Objetivo: discutir as intenções e apresentar a proposta de estudo (entrevista e observação).

$3^{\text {a }}$. Etapa - Visita às instalações, coleta de documentos e agendamento das entrevistas, bem como análise preliminar de documentos a serem colhidos - mês de dezembro de 2003.

Objetivo: conhecer o processo operacional e coletar documentos e registros referentes ao objeto de estudo, além de montar um cronograma de entrevistas com gestores, gerentes, encarregados, olheiros e atletas do clube (observação, entrevistas).

4a. Etapa - Entrevistas e análises dos documentos - mês de janeiro e fevereiro de 2004.

Objetivo: esta fase caracteriza-se como "o momento da investigação empírica", é imprescindível para a busca de evidências e respostas para as questões que se pretende investigar no referido estudo de caso.

De maneira específica, os resultados do estudo são apresentados em quatro momentos.

\section{$1^{\circ}$ MOMENTO:}

- coleta de informações gerais sobre o sistema e seus subsistemas (institucional, físico, organizacional, social, gestão e informação);

- identificação das evidências do processo de avaliação econômica / financeira de jogadores de futebol e o processo de gestão do clube.

\section{$2^{\circ}$ MOMENTO:}

- verificação e acompanhamento do processo físico-operacional.

\section{$3^{\circ}$ MOMENTO:}

- $\quad$ apresentação das decisões identificadas na pesquisa;

- diagnóstico das variáveis relevantes dos eventos ligados ao processo de avaliação econômica de atletas em formação e atletas profissionais. 


\section{$4^{\circ}$ MOMENTO:}

- análise e interpretação de dados, documentos e estatísticas sobre os respectivos processos, com intuito de apontar evidências sobre o processo de avaliação praticado pelo clube.

Em resumo foram realizadas diversas visitas às instalações do clube para verificar e acompanhar o processo físico-operacional. Também foram realizadas diversas entrevistas com os seguintes grupos:

Primeiro Grupo: Gestores administrativos (vice-presidente, conselheiros e superintendentes);

Segundo Grupo: Gestores financeiros (contadores, administradores e gerentes patrimoniais);

Terceiro Grupo: Gestores esportivos (gestores científicos e esportivos, técnicos, gerentes, olheiros e demais profissionais e encarregados das atividades operacionais esportivas);

Quarto Grupo: Atletas profissionais e amadores e demais profissionais ligados às atividades do futebol.

\subsubsection{A escolha do caso}

A escolha do Clube Atlético Paranaense para estudo de caso baseou-se nos seguintes aspectos do clube:

- $\quad$ apresentou destaque em termos de gestão administrativa, esportiva e financeira entre os maiores clubes esportivos brasileiros na última década;

- $\quad$ adquiriu espaço junto aos meios de comunicação;

- implementou e estruturou o "Estádio da Arena" que, de acordo com a imprensa, escrita e falada, é modelo mundial para espetáculos ligados ao futebol;

- desenvolveu e aplicou metodologia para o processo de seleção e formação de jogadores para as diversas categorias de base;

- $\quad$ ofereceu diversos atletas às várias categorias da seleção brasileira (sub-17, sub-20, sub-23 e a seleção principal); 
- participou e participa ativamente do mercado de negociação de jogadores, (formando, comprando, vendendo e emprestando) atletas para clubes nacionais e internacionais.

Destaca-se que as análises dos resultados foram realizadas conjuntamente com a descrição dos dados obtidos nas entrevistas e observações do processo físico-operacional. Os resultados são apresentados em quatro momentos:

- As características do ambiente externo e interno do clube;

- $\quad$ O processo físico-operacional, ou seja, o processo de formação de jogadores;

- As decisões identificadas na pesquisa, bem como as variáveis relevantes ligadas ao processo de avaliação de atletas; e

- $\quad$ Análise e interpretação dos dados. 


\section{ESTUDO DE CASO - CLUBE ATLÉTICO PARANAENSE}

Este capítulo tem como objetivo demonstrar os resultados do estudo de caso realizado. Assim sendo, os comentários e as considerações sobre as evidências provenientes das entrevistas e das análises de documentos serão discutidas no transcorrer deste capítulo.

\subsection{Características do ambiente interno e externo}

\subsubsection{Aspectos históricos}

O clube Atlético Paranaense foi fundado em 26 de março de 1924, pela fusão do América Foot Ball Club e do Internacional Foot Ball Club. Segundo o estatuto do clube, ele configurase como uma sociedade civil sem fins lucrativos e de duração ilimitada, cuja finalidade é o desenvolvimento das relações sociais através da prática de atividades recreativas, culturais, artísticas e esportivas sem fins lucrativos. O clube mantém quadros de futebol profissional e amador; não mantém atividades recreativas para os sócios, nem outras modalidades esportivas.

\subsubsection{Mercados, clientes, fornecedores e concorrentes}

Nesta seção serão apresentados os levantamentos das atividades operacionais que têm como objetivo conhecer a realidade físico-operacional e o sistema de gestão da respectiva entidade, subdividida em mercados, clientes e fornecedores.

O CAP - Clube Atlético Paranaense atua especificamente no mercado de futebol profissional e em todas as categorias de base do futebol amador. O mercado produzido pela arena é considerado como segundo plano; o principal é o futebol profissional. Contudo, o futebol amador tem como objetivo o desenvolvimento de atletas que irão dar suporte ao futebol profissional, suprindo e repondo atletas.

Nas entrevistas e levantamentos realizados, no tocante aos aspectos do ambiente externo, constatou-se que o clube atua fortemente na formação de jogadores, mas o "carro chefe" é o 
futebol profissional que serve de vitrine, tanto para exposição da marca como para a venda de atletas formados nas categorias de base.

As categorias de base têm a função de fornecer peças de reposição à equipe principal - o futebol profissional -, ou seja, jogadores aptos a atuarem no futebol nacional e mundial.

O número de atletas revelados demonstra o quanto a Marca do Clube Atlético Paranaense vem sendo difundida ${ }^{28}$ no estado do Paraná, tanto em número de torcedores, como escolinhas franqueadas, núcleos de aprendizado de futebol que são coordenados pela comissão científica da entidade. Todo esse espaço obtido entre os principais times brasileiros é fruto de suas conquistas nos principais campeonatos (estaduais e nacionais).

A atuação do CAP no mercado de jogadores tem demonstrado que o clube dispõe de um relacionamento significativo no que tange a negociações de jogadores com inúmeros países, “[...] temos um relacionamento muito grande com a Europa, com a Ásia e com América Central." ${ }^{29}$ Observou-se também que, além deste, o mercado interno é formado pela negociação de jogadores, pela renda dos jogos e do televisionamento.

A venda de jogadores para o mercado externo tem a finalidade de suprir a falta de recursos para cobrir os custos operacionais, uma vez que o clube não se auto-sustenta apenas com a renda dos jogos televisionados, patrocínios e venda de ingressos. Diante dos gastos com o plantel de jogadores que o CAP possui, o clube se vê obrigado a desenvolver e negociar atletas.

No que diz respeito aos principais clientes do Atlético, apontam-se: os torcedores, os clubes nacionais e internacionais, as federações, as ligas e a TV (mídia). Ressalta-se que a mídia é de suma importância para os clubes brasileiros, pois a maior parte das receitas origina-se de contratos de transmissão dos jogos, tanto dos campeonatos estaduais, quanto regionais, nacionais e internacionais.

Sobre os clientes do CAP, os gestores relataram:

\footnotetext{
${ }^{28}$ Em pesquisa realizada pela DATAFOLHA sobre o número de torcedores na capital e no interior e o seu crescimento na última década.

${ }^{29}$ Gestor Administrativo.
} 
[...] trabalhamos com todos os clubes e empresários de futebol, em forma de parcerias. Fora do país nós não trabalhamos com parcerias, somente com a venda de jogadores. (Gestores Administrativos)

No que diz respeito às Federações e Confederações,

[...] não temos negócios, somos apenas filiados a eles e respeitamos as regras do jogo impostas por eles para os campeonatos. (Gestores Administrativos)

Quanto aos clientes ligados à mídia, a renda auferida pelos televisionamentos é expressiva, ou seja, “a TV não é só um cliente, mas um "parceiro"”. O relacionamento econômico entre a TV e os clubes funciona da seguinte forma:

[...] toda vez que eles vão transmitindo e fazendo reportagens dos jogos, eles vão reembolsando o valor do patrocínio. (Gestores Administrativos)

Observa-se que não só para o CAP, mas para todos os clubes do Brasil, existe uma dependência financeira muito forte dos clubes com a mídia (TV), tornando-a uma parceira importante, pois os repasses que são realizados em função da previsão da tabela de jogos, hoje são tidos como a salvação de todos os clubes de futebol. Logo, a renda de televisionamento corresponde a uma boa parte da renda dos clubes.

Ao indagar se as empresas de marketing esportivo e licenciamentos são boas clientes, os gestores afirmaram que,

[...] no nosso caso específico, não temos uma empresa que gerencia e explora a nossa marca, mas não com a devida relevância. (Gestores Administrativos)

Atualmente, a empresa que cuida deste segmento no clube é a $\mathrm{UMBRO}^{30}$, porém ela está limitada à produção de camisas e material esportivo em geral. Acredita-se que este segmento ainda não é muito explorado no Brasil.

De acordo com os gestores no clube, o marketing esportivo e licenciamentos

30 UMBRO - Empresa que atua no ramo de produção de materiais esportivos. Atualmente é a empresa que explora a marca Atlético Paranaense, além de fornecer todo o material esportivo necessário às atividades de futebol do CAP. 
[...] deveriam ser gerenciados por uma empresa com grande expressão no mercado, pois, caso contrário, os resultados não são satisfatórios. Tem que ser uma empresa com marketing forte e com grande experiência, para gerar bons resultados para o clube. (Gestores Administrativos)

Deve-se lembrar que este segmento de produtos licenciados no Brasil sofre com a "pirataria" "31. Dentre as fontes de receitas, na relação econômica entre os sócios e o CAP, constatou-se que existem três modalidades de sócios:

- $\quad$ o sócio torcedor - comparece somente aos jogos, mas adquire produtos relacionados à marca do clube;

- o sócio contribuinte - contribui constantemente com o clube, além dos pagamentos regulares, faz doações financeiras ao clube; e

- $\quad$ sócio ouro - sendo que esta última modalidade de sócio adquire uma "cadeira" por tempo determinado (cerca de 10 anos) e paga taxa de manutenção anual.

No âmbito dos principais fornecedores, aponta-se a UMBRO no fornecimento de material esportivo a todas as categorias de futebol como uniformes, bolas, chuteiras, meias, agasalhos etc.

No tocante à questão de seus principais concorrentes, observaram-se dois níveis de concorrentes.

[...] para um clube o principal concorrente são os outros clubes; nos campeonatos estaduais são os clubes locais; nos campeonatos nacionais são os clubes do eixo Rio - São Paulo. Eles são muito fortes na hora fechar contratos, pois são os que mais absorvem a renda de televisionamento, patrocínio. (Gestores Administrativos)

Para os gestores administrativos, os clubes grandes conseguem melhores contratos pelo fato de possuírem maior volume de torcedores,

[...] eles recebem a maior parte da renda de televisionamento.

A torcida exerce influência nos contratos de patrocínio, a exemplo da venda de camisas.

Os gestores administrativos e financeiros do clube apontaram que a maioria das entidades esportivas não consegue obter receitas suficientes para cobrir todos os gastos operacionais. 
Mesmo o Atlético, tendo à disposição uma estrutura avançadíssima, onde o torcedor tem conforto e todo apoio logístico para o entretenimento e consumo, as receitas totais geradas ainda são insuficientes, buscando-se alternativas como a negociação de jogadores, estratégia esta utilizada para equilibrar as contas do clube.

\subsubsection{Governo, federações e legislações vigentes}

Constatou-se que o governo em seus diversos níveis não tem influência direta, mas sim indireta pelo Ministério do Desporto, Ministério da Previdência e Secretaria da Receita Federal. Esta influência indireta é vista nas diversas legislações vigentes, que regulamentam cada parte que forma o segmento esportivo brasileiro.

Ao questionar-se sobre as legislações vigentes que influenciam a relação entre jogadores e o clube, os gestores afirmam que

[...] hoje a Lei Pelé é a base principal para a negociação e registro de jogadores. (Gestores Financeiros)

Sobre a questão tributária, abordam que

[...] o clube é tratado como uma empresa normal; só temos que pagar tributos, apenas nas áreas que atuamos e que incidem tributos, no mais é igual a qualquer outra empresa. (Gestores Financeiros)

De maneira específica, apontam-se as seguintes legislações que regulamentam as atividades do desporto brasileiro:

\section{a) Lei Pelé - aspectos financeiros e econômicos (Demonstrações Financeiras /}

Publicações) - Lei 9615/98, que torna obrigatório que clubes, ligas e federações publiquem as demonstrações financeiras de acordo com a legislação contábil vigente.

No que diz respeito às demonstrações financeiras, o governo federal determinou através da Lei Pelé que,

[...] nós estamos obrigados à publicação das demonstrações de acordo com a Lei das S/As. Ainda que não exista uma legislação específica, como exemplo, não temos um plano de conta específico,

31 Pirataria: termo utilizado para definir prática, ou seja, a produção e comercialização de produtos falsificados. 
atualmente nós usamos um plano misto (comercial e industrial), pois precisamos apurar os centros de custos. (Gestores Financeiros)

Segundo os gestores, os clubes subsidiam-se, para elaboração e publicação das demonstrações, na Lei da S/As. Neste ponto, os gestores financeiros argumentaram que, devido à ausência de uma norma contábil específica para o setor esportivo, há uma disparidade nas demonstrações financeiras entre os clubes da Federação, principalmente no tocante ao reconhecimento, mensuração e evidenciação de itens como: receitas, despesas, custos, ativos e passivos.

b) Estatuto do Torcedor - O relacionamento entre torcedores e clubes atualmente é regulamentado pelo Estatuto do Torcedor que tem como objetivo resguardar os direitos e deveres entre clube e torcedores, tanto em competições estaduais, quanto regionais e nacionais. No que se refere ao estatuto do torcedor, os gestores administrativos argumentam que

[...] nós não tivemos problemas, graças à arena ter sido desenvolvida sob uma nova visão. Nós estávamos completos tivemos apenas que colocar em edital as normas do campeonato e criar uma ouvidoria.

O estatuto do torcedor foi implementado com a finalidade de estabelecer direitos e deveres entre clube e torcedores, assegurando a este relacionamento integridade de clubes e de fãs do futebol.

\subsubsection{Missão, objetivos e estratégias}

Na visão dos gestores administrativos, a missão do clube é vencer campeonatos,

[...] é chegar na final dos campeonatos com a taça na mão.

Afirmam que a busca pelos títulos é a melhor estratégia, pois,

[...] quanto maior o número de vezes que o clube conseguir chegar na final dos campeonatos, melhor será o desempenho em termos financeiros, quer seja em bilheteria como patrocínio. 
Observa-se que, à medida que o clube chega à final dos campeonatos, aumenta também o seu "leque de torcedores". Deste modo, os torcedores que estão em dúvida passam a admirar e torcer pelo clube vitorioso.

Constatou-se que, para os gestores administrativos, o cumprimento desta missão depende diretamente da conquista dos campeonatos,

[...] neste ano queremos chegar entre os quatro primeiros clubes brasileiros.

Observou-se que as metas são periodicamente revistas e ajustadas em função da missão do clube. Pensando no futuro, o clube realizou um planejamento para atender suas atividades programadas até 2010 registradas em ata,

[...] os nossos objetivos para os campeonatos nacionais. Por exemplo, para o campeonato do ano 2004 e nos próximos dois anos, o nosso objetivo é ser campeão. (Gestores Administrativos)

Verifica-se a sinergia existente entre a missão e os objetivos do clube. E, com base neste planejamento, é projetado o futuro do clube. Todo trabalho executado pela comissão de estudos científicos do Centro de Treinamento - $\mathrm{CT}^{32}$ obedece ao que está estabelecido no planejamento. A comissão gestora do clube define:

[...] nós dizemos onde queremos chegar. Para isso a comissão científica deve desenvolver atletas, pois proporcionamos todas condições necessárias. (Gestores Administrativos)

Diante disto, implementou-se uma filosofia de trabalho para formação de atletas; segundo os gestores administrativos,

[...] o clube que queremos é um clube de permanência eterna. Não queremos um clube somente para o momento, mas para o futuro; este é um dos motivos que nos leva a ter uma metodologia avançada para desenvolver nossos próprios jogadores.

O que se pretende é desenvolver um sistema que dê suporte ao clube, daqui para frente, com objetivo de

[...] implementar esta filosofia de trabalho. Para tanto, foi necessário trazer técnicos, cientistas de esportes que, em conjunto com médicos e fisioterapeutas, desenvolveu uma metodologia com alto grau de perfeição, cuja técnica hoje estamos desfrutando, que nos permite desenvolver e vender jogadores, e obter preços fabulosos nas negociações, graças às estratégias desenvolvidas pelos diretores do CAP junto aos empresários ligados ao futebol. (Gestores Administrativos)

\footnotetext{
${ }^{32}$ CT - Centro de Treinamento: local onde é realizado o processo de treinamento e formação dos atletas do Clube
} Atlético Paranaense. 
Portanto, esta metodologia possibilita desenvolver jogadores num prazo bastante curto com efeitos comerciais que supram as necessidades de caixa do clube.

As novas tecnologias e metodologias implementadas no clube são fruto da nova gestão do CAP,

[...] antes da implementação foram estudados vários projetos do mundo inteiro. (Gestores Administrativos)

Neste ponto, a Arena foi desenvolvida com uma tecnologia que leva em consideração o torcedor que assiste aos jogos, pois a estrutura dela proporciona ao torcedor a sensação de estar muito próximo do campo, além de integrar serviços para satisfação e segurança deste torcedor, a exemplo destacam-se: o escoamento de torcedores, o trânsito interno, os banheiros e as lanchonetes.

No tocante aos planos estratégicos elaborados pelo Conselho Deliberativo, nota-se que houve, em termos de gestão, uma adoção dos conceitos de planejamento estratégico aplicado pela iniciativa privada. Os gestores administrativos afirmam que

[...] atualmente o clube mantém um perfeito sincronismo na área técnica esportiva com a área administrativa - financeira.

Com este modelo de gestão estratégica o clube busca a sua auto-suficiência, tanto na formação de jogadores como na produção de espetáculos que tragam o equilíbrio financeiro.

A busca do equilíbrio é sempre precedida da indagação:

[...] a renda de televisionamento e de bilheteria são suficientes para cobrir $70 \%, 80 \%$ ou $100 \%$ dos nossos custos? Se não for, então, nós deveremos negociar determinados jogadores. (Gestores Administrativos)

Identificou-se a existência da interação entre os gestores administrativos, financeiros e esportivos. Sendo assim, foram indagados: quais são os planos do CAP? Onde o clube pretende chegar?

Primeiramente pretendemos aumentar o número de torcedores em relação aos grandes clubes brasileiros. Se compararmos hoje o CAP, em termos de torcida, somos um clube pequeno, mas se compararmos em termos financeiros somos considerados um grande clube. Esta é uma das razões da necessidade de se ganhar título. Para isso estamos investindo e dando todo o suporte necessário 
à comissão técnica de futebol para que haja um aumento no leque de torcedores do clube. (Gestores Administrativos)

Detectou-se que toda a estratégia do clube para a formação esportiva de seus atletas leva em consideração os investimentos em marketing. Uma das estratégias vincula-se à realização de convênios, em diversas cidades do estado do Paraná, como escolinhas de futebol que têm por objetivo desenvolver, divulgar e consolidar o nome do clube. Nesses convênios, disponibilizam-se a "marca", a tecnologia e oferece-se qualificação aos profissionais que farão o treinamento dos meninos.

Estas escolinhas ficam registradas em nome do CAP e usam o uniforme do clube, são consideradas parceiras como se fossem "franquias". Atualmente o CAP tem 6 escolinhas na capital e 12 escolinhas no interior, com perspectiva de estender a outros estados, a exemplo do estado de Minas Gerais, onde já é oferecida a tecnologia do CAP para o desenvolvimento de atletas.

O Clube Atlético Paranaense busca desenvolver estratégias que corroboram o que diz Maximiano (1985, p.19):

[...] o processo de desenvolver estratégias observando a relação pretendida da organização com seu ambiente. Assim, o planejamento estratégico é na prática um filtro da viabilidade futura, onde os planos estratégicos revelam as oportunidades do amanhã ao apresentar as seguintes características: Ilumina oportunidades de novos espaços; extrapola as fronteiras das unidades de negócios; revela as necessidades dos clientes; proporciona insight para elaboração de regras no setor; engloba a ameaça de concorrentes.

Em relação ao planejamento estratégico, verificou-se que o CAP possui planejamento estratégico com vigência até 2010. Os gestores afirmam existir o acompanhamento e a avaliação do planejamento estratégico.

[...] a exemplo da arena que deveria ser concluída neste ano, e que, por motivos alheios à nossa vontade, tivemos que reformular o Planejamento Estratégico prevendo a sua conclusão definitiva para os próximos anos. (Gestores Administrativos)

Nas etapas do planejamento, o clube realiza o planejamento operacional para determinar: $\mathrm{O}$ que fazer? Como fazer? Quando fazer? E quanto de recursos? Esta ferramenta é imprescindível à execução e integração das atividades e operações do clube. 
O clube encontra-se dividido em setores: administrativo, manutenção, patrimonial e futebol. O setor de futebol é dividido em profissional e amador e os demais setores têm função de apoio à área esportiva. $\mathrm{O}$ futebol profissional consiste na equipe principal e o amador em categorias de base. Desta forma, apesar de o clube possuir atividades programadas até 2010, realiza a revisão do planejamento a cada temporada anual.

\subsubsection{Gestão, estrutura e funções}

Para o gerenciamento e a execução das atividades, o CAP buscou adotar um modelo de gestão que se adapta às mudanças do desporto brasileiro. Tendo em vista que o clube sofre atualmente com as diversas alterações, a exemplo da extinção do passe, o estatuto do torcedor e outros, busca adaptar-se constantemente às legislações vigentes.

O CAP possui um Conselho Deliberativo, um Conselho Gestor, um Conselho Administrativo e um Conselho Científico de futebol, em que os diretores e executivos contratados executam suas atividades como se estivessem numa empresa privada.

Desta forma, a gestão encontra-se descentralizada em áreas e departamentos, assim distribuídos: Gestores administrativos; Gestores financeiros; Gestores jurídicos, totalizando 12 gestores, responsáveis pelas áreas administrativas, patrimonial e de futebol.

Os gestores afirmam ter autonomia para o gerenciamento de suas atividades de maneira que

[...] existe sintonia entre os gestores na execução das atividades. (Gestores Administrativos)

Todo esse processo de atribuição de responsabilidade encontra-se formalizado em ata e no estatuto do clube. Em relação à avaliação de seu desempenho, os gestores afirmam:

[...] não há indicadores para a avaliação do desempenho dos gestores. Se existe fica restrito ao conselho gestor. (Gestores Administrativos) 


\subsubsection{Gestão administrativa do clube}

A administração do clube é realizada por seus próprios sócios, através de mandatos eletivos e todas as demais atividades e finalidades do Clube Atlético Paranaense são reguladas conforme estatuto e disposições legais vigentes.

Quanto à marca, símbolos, cores, hinos, bandeiras, distintivos e uniformes, são elementos que representam e constituem o patrimônio cultural do clube a ser preservado pelos sócios e atletas.

A administração e a gestão do CAP são compostas pelos seguintes órgãos: Assembléia Geral; Conselho Deliberativo; Conselho Administrativo; Diretoria e Conselho Fiscal.

A Assembléia Geral é composta pelos sócios no uso do seu gozo, a qual será presidida pelo presidente do Conselho Administrativo, e reunir-se-á ordinariamente a cada dois anos e extraordinariamente a qualquer tempo. A convocação dos membros da Assembléia Geral é feita pelo presidente do Conselho Deliberativo ou pelo presidente do Conselho Administrativo ou ainda pelo número mínimo de 150 sócios.

O Conselho Deliberativo tem como atribuições eleger, empossar e destituir, a qualquer tempo, os membros dos conselhos administrativos, bem como representar o clube em qualquer outra atividade como: legislação do desporto profissional, atribuições econômicas e financeiras, fiscais e consultivas, no que diz respeito às atividades do clube.

Sua estrutura administrativa organizacional está disposta atualmente da seguinte forma:

- Comissão Gestora: Presidente, Planejamento, Entidades visitantes, Médico, Financeiro, Jurídico, Futebol Amador;

- Conselho Deliberativo: Presidente; Primeiro vice-presidente; Segundo vice-presidente; Primeiro secretário; Segundo secretário;

- Diretoria Executiva: Diretor Superintendente; Diretor de Patrimônio; Diretor de Marketing; Diretor Financeiro;

- Comissão Técnica Administrativa: Diretor de Futebol; Diretor Técnico; Assessor Científico, Assessor Executivo, Coordenador de Futebol Profissional, Coordenador das 
Categorias de Base, Administrativo e Administrativo/Informática; Departamento de Registro;

- Comissão Médica: Diretor; Médico A; Médico B; Médico C; Médico D; Fisioterapeuta A; Fisioterapeuta B; Fisioterapeuta C; Fisiologista; Nutricionista; Psicólogo; Dentista;

- Comissão de Apoio: Roupeiro; Auxiliar de Roupeiro; Massagista A; Massagista B.

\subsubsection{Organograma}

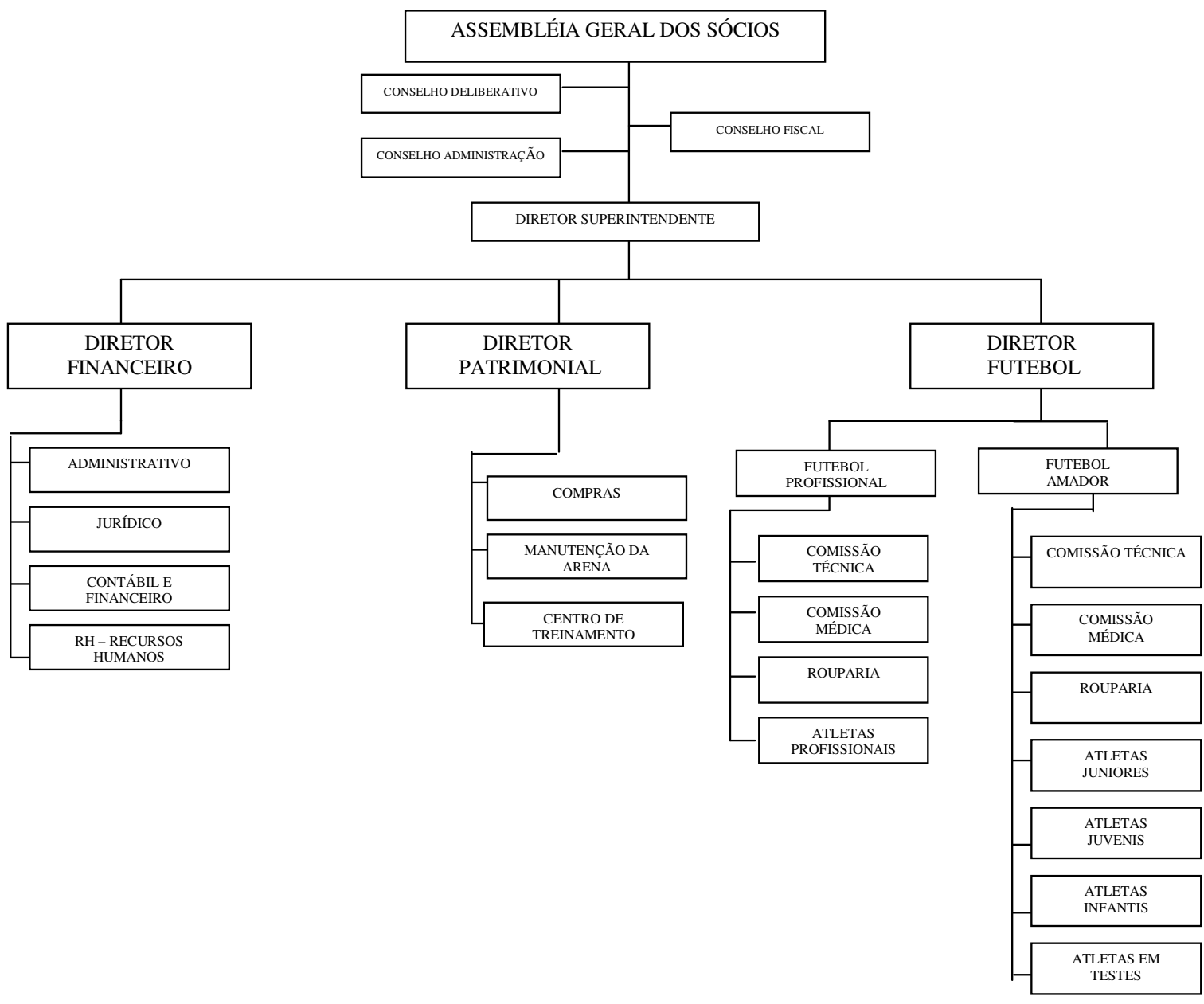

Figura 6 - Organograma 
O Centro de Treinamento está subordinado ao Diretor de Patrimônio e possui um administrador responsável pela "logística" em nível de gerência. O gestor tem a função de integrar as demais áreas do CT para que funcione de forma conjunta, pois toda a estrutura do CAP, "toda logística”, está em função do futebol profissional.

Observa-se que a contratação dos gestores fica a cargo do Conselho Deliberativo que leva em consideração a formação técnica. Por exemplo,

[...] a gestão tributária do clube é executada por um profissional especialista da área e, além disso, o clube recebe consultoria de empresas de auditoria independente. (Gestores Financeiros)

Nos Departamentos Jurídico e Financeiro, os profissionais são todos contratados e possuem "vasta experiência" na área em que atuam. Identifica-se que, de fato, existe uma qualificação técnica dos gestores no exercício de suas respectivas funções.

O clube tem a política de proporcionar melhor qualificação aos seus empregados nos diversos níveis.

$\mathrm{Na}$ área técnica desportiva, a qualificação dos atletas, tanto profissionais como amadores, é desenvolvida por profissionais qualificados (médico, fisioterapeutas, professores de educação física e psicólogos). Além da formação esportiva, o clube oferece e incentiva os atletas a desenvolverem outras habilidades e conhecimentos em outras áreas: desenvolvimento social, emocional, educacional. Segundo os gestores,

[...] nós não vendemos um jogador para a Europa sem nenhum nível cultural. Nós matriculamos e levamos os atletas à escola. Se algum atleta obtiver notas baixas na escola, este é encaminhado ao professor disponibilizado no próprio CT. É o professor quem administra toda essa parte. Ele vai à escola e procura saber o que está acontecendo com o aluno. Temos uma preocupação social com a formação do indivíduo. Pois, a hora que ele quiser interromper sua carreira no futebol, ele já possuirá uma formação mínima para enfrentar o mundo lá fora. (Gestores Administrativos)

$\mathrm{Na}$ área administrativa, o CAP também tem uma política de qualificação para os seus funcionários, ou seja, estes são qualificados por profissionais do Serviço Nacional de Aprendizagem Comercial - SENAC, com o qual o clube mantém parceria. 


\subsubsection{Sistemas de informações e a gestão}

Os sistemas de informações têm como objetivo subsidiar a gestão do clube. Nos levantamentos realizados no estudo de caso, pôde-se averiguar que os departamentos financeiros do clube não realizam nenhum tipo de planejamento financeiro-econômico para a contratação de atletas, sendo que as contratações ficam sob a responsabilidade dos gestores que executam o processo de negociação de atletas. Os gestores analisam se as contratações pretendidas encontram-se dentro dos limites financeiros estabelecidos pelo clube.

Diante das evidências apontadas nas entrevistas e levantamentos, assegura-se que as contratações são realizadas em função das necessidades ou exigências da comissão técnica e podem acontecer a qualquer momento. Entretanto, o aval financeiro é realizado pelos conselheiros, ou seja, são eles que determinam quanto o clube irá gastar na temporada.

Conclui-se que o processo de contratação acontece pelo encaminhamento das propostas ao Conselho Deliberativo. Deste modo, eles determinam se a transação é financeiramente viável ou não.

Ainda no que se refere à questão de planejamento, certifica-se que apenas as decisões de vendas são planejadas. Grande parcela das vendas acontece porque o clube atua no segmento de formação de atletas. Porém, os gestores confirmam que as negociações são motivadas pelas limitações financeiras do clube, pois as receitas geradas ${ }^{33}$ pelas atividades ligadas ao futebol não são suficientes. Segundo os gestores,

[...] somos obrigados a negociar alguns atletas com a finalidade de equilibrar as contas do clube. (Gestores Administrativos e Financeiros).

Deve-se ressaltar que a finalidade do clube não é exclusivamente a venda de atletas.

No que diz respeito ao momento em que os atletas são negociados, destaca-se que não existe prazo específico, mas normalmente na fase de juniores eles não são negociados, pois os gestores administrativos alegam que o atleta nesta fase não é oneroso para o clube, pois os

33 Relatos apurados nas entrevistas com os Gestores Financeiros e Administrativos (2004): as atividades operacionais ligadas aos jogos (futebol) não produzem receitas suficientes. Deste modo, faz-se necessária a venda de pelo menos um jogador por temporada, para que o clube consiga equilibrar suas contas. 
únicos gastos que incorrem são relacionados à sua manutenção, pois eles ainda não recebem salários.

Desta forma, conclui-se que a política do clube consiste basicamente em negociar atletas profissionais. Por outro lado, o clube adquire jogadores que ainda se encontram em processo de formação, pagando ao clube formador para que libere os atletas.

Os gestores financeiros afirmam, ainda:

[...] não temos um sistema para avaliar eventos relacionados à negociação de jogadores.

Observa-se, nesta fala, que as transações executadas pelos gestores não são avaliadas em consonância com o desempenho do clube. De um modo geral, os gestores não realizam uma análise financeira e econômica dos principais eventos como a formação, venda, aquisição, empréstimos, permutas e até renegociação de contratos. As decisões realizadas não estão apoiadas em uma metodologia que reflita o impacto econômico de cada decisão no resultado e no patrimônio do clube.

\subsubsection{O sistema contábil do clube}

O sistema de contabilidade que se encontra disponível aos técnicos, gerentes e diretores caracteriza-se como um sistema de contabilidade formal, onde são elaborados apenas relatórios como balanços, balancetes mensais, orçamento mensal, custo médio por jogadores, ou seja, demonstrações básicas.

O clube adota metodologia para apuração dos custos médios por jogadores, sendo que o custo médio por atleta contempla os custos operacionais como custos de pessoal (treinamento), material esportivo, medicina esportiva, alimentação, e demais custos ligados à logística do CT - Centro de Treinamento.

No que diz respeito aos controles gerenciais, observa-se a ausência de uma contabilidade gerencial de suporte às decisões. Os gestores financeiros afirmam que um acompanhamento econômico dos investimentos realizados tanto na aquisição quanto na formação dos atletas é algo que 
[...] seria difícil de realizar, tendo em vista o número de jogadores profissionais e amadores que o clube possui.

\subsubsection{A importância do orçamento}

Dentro dos relatórios elaborados pelo Departamento de Contabilidade, destaca-se o orçamento realizado para as atividades operacionais, sendo que, da fase de elaboração até a de execução, existe um período de acompanhamento e avaliação das metas e planos estabelecidos. Por outro lado, não existe adoção de indicadores externos, os indicadores utilizados na avaliação do desempenho econômico e financeiro foram elaborados pelos próprios gestores e são utilizados apenas por eles mesmos, não sendo de interesse da diretoria.

Os gestores do departamento financeiro abordaram que

[...] a diretoria quer ver mesmo são os números, e não indicadores.

Nota-se que a diretoria requer informações sobre o quanto entrou de recursos e o quanto saiu no período, ou seja, qual é o resultado completo durante um ano.

\subsubsection{Ativos, passivos e o patrimônio do clube}

Os relatórios financeiros do clube viabilizam as constatações e análises sobre a existência de ativos fixos (tangíveis) e intangíveis, sendo que a Arena da Baixada e o Centro de Treinamento representam os ativos fixos de maior expressão. No que diz respeito aos ativos intangíveis, de acordo com os gestores, a marca Atlético Paranaense e os jogadores profissionais e amadores representam os ativos intangíveis valiosos para o clube.

Em relação aos passivos, observou-se que a dívida renegociada com o Governo Federal, o Programa de Recuperação Fiscal - REFIS, representa o passivo de maior expressão, atualmente, para o clube, ainda que os salários dos jogadores sejam também considerados uma obrigação bem significativa não só para o Atlético Paranaense como para os demais clubes brasileiros.

Em relação ao grau de endividamento do clube, percebeu-se que o respectivo clube se encontra em situação favorável, pois honra seus compromissos com fornecedores e com os 
órgãos públicos. No tocante ao capital de giro, os gestores do clube salientam que este é suficiente para as exigências do ciclo operacional. Deste modo, o clube consegue equilibrar as operações financeiras.

O patrimônio social do clube apresenta-se composto por diversos sócios que contribuem com taxas de manutenção.

Dentre os principais custos destacam-se aqueles ligados às atividades operacionais como os jogos de futebol, as atividades de manutenção da Arena (estádio), manutenção do centro de treinamento e os salários dos jogadores.

\subsection{Processo físico-operacional de formação de jogadores de futebol}

O processo de formação de atletas atual no Clube Atlético Paranaense encontra-se dividido em várias etapas. Os gestores esclarecem que o processo de formação inicia-se pela fase denominada de oportunização motora ${ }^{34}$, caracterizada como o momento no qual são oferecidas, a todas as crianças, as condições necessárias para que possam chegar ao futebol.

A oportunização motora, segundo os gestores científicos e técnico-esportivos, tem mostrado ao longo do tempo, através de

[...] vários estudos científicos, que para você detectar um talento é necessário que haja uma grande quantidade de crianças praticando o futebol.

Observa-se que o CAP, não tendo uma estrutura física que suporte criação e implementação das escolinhas dentro do próprio clube, utilizou-se da estratégia de criação de núcleos fora, através da realização de parcerias com clubes menores.

Com a adoção desta estratégia de criação de núcleos, o Atlético Paranaense consegue atender as necessidades de formação de atletas e divulgação da marca do clube, sendo que os núcleos atualmente já se encontram espalhados nos diversos Estados da Federação, tanto no interior

34 O diretor científico de futebol do Clube Atlético Paranaense define oportunização motora como a oportunidade oferecida às pessoas de estarem em contato com a prática esportiva de qualquer modalidade. 
como na própria capital, além de Santa Catarina, Minas Gerais, Nordeste, ou seja, já existem núcleos em vários Estados.

É importante elucidar o que de fato são estes núcleos. Os gestores esportivos informam que os núcleos funcionam como

[...] convênios realizados com clubes pequenos, chamados de oportunização, neste momento não é levado em consideração se os meninos sabem ou não sabem jogar futebol.

Este processo é denominado de recrutamento de prováveis atletas, ou seja, a busca de meninos para o futebol.

Neste processo de formação, os núcleos têm a função de

[...] encaminhar os meninos que se destacarem ao CAP. Os meninos, sendo aprovados nos testes, entram para o processo de formação e, se no futuro vendermos os atletas, então é repassado um percentual ao núcleo. (Gestores Esportivos)

O clube disponibiliza todo o apoio necessário à formação dos professores e técnicos que trabalham nos núcleos, ou seja, todo processo de formação e capacitação técnico esportiva é realizado pelo CAP, além de disponibilizar todo o material esportivo necessário para a prática do futebol. No entanto, os núcleos

[...] não são considerados como franquias, equivalem a franquias. Pois o clube trabalha com o sistema de franquia. (Gestores Esportivos)

\subsubsection{Os requisitos para seleção de talentos}

Estes grupos ou núcleos têm como objetivo a oportunização dos atletas, ou seja, viabilizar sua entrada no futebol profissional. Deste modo, os atletas que se destacam nos núcleos são encaminhados ao CAP, onde participam de um programa chamado "Seleção de Talentos". Os meninos pré-selecionados nos núcleos passam em torno de 7 a 8 dias no clube. Neste período os atletas passam por uma bateria de exames, tais como: exame médico; psicológico, no qual são analisadas as capacidades de concentração, o emocional, o estado de stress, ansiedade. Todos estes testes são orientados por um protocolo de psicologia. 
O menino que não apresentar nenhuma patologia é, então, encaminhado ao departamento esportivo, onde serão realizados os testes ligados à área esportiva, como avaliação fisiológica, velocidade, força, resistência, habilidade motora com a bola, precisão de chutes, precisão de passes, controle da bola.

Além destas avaliações, verifica-se também "A Inteligência Tática", lembrando que não é cobrado dele (menino) o conhecimento de um sistema tático esportivo, mas é observada a visão de jogo do futuro atleta e seu comportamento dentro de campo.

Os gestores esportivos descrevem que, no processo de seleção, é realizada a aplicação de metodologia específica,

[...] existe uma tabela numérica para cada requisito, ou seja, o atleta recebe pontos por cada quesito durante uma semana, no final do processo os atletas que atingirem maior número de pontos são considerados como os melhores talentos do grupo.

A exemplo da aplicação desta metodologia, o gestor científico de futebol ilustra que,

[...] no ano passado, foram avaliadas, aproximadamente, 800 crianças das quais somente 4 foram aprovadas.

Os gestores esportivos ligados ao processo explicam que

[...] o atleta considerado como bom não interessa para o clube. Nós queremos o desvio padrão. A adoção deste processo tem oferecido ao processo de formação muito segurança.

Isto pode ser comprovado nos números apresentados pelo departamento científico de futebol. Dos atletas que compunham a equipe principal no ano de 2003, 14 atletas eram fruto da categoria de juniores.

Os gestores esportivos afirmam que

[...] o retorno econômico é sensivelmente visível, se fosse realizada uma avaliação financeira em janeiro de 2003, poderia se constatar que os atletas formados pelo clube 'avaliados a preços de mercado' valeriam, aproximadamente, de 7 a 8 milhões de dólares, se fossem avaliados em dezembro valeriam aproximadamente 80 milhões de dólares.

Conclui-se que o processo de formação do clube representa grande importância tanto no aspecto esportivo como nos econômicos e financeiros. 
Deve-se ressaltar que, tendo em vista esta metodologia de seleção e formação de atletas do CAP, a figura do olheiro não é tão importante para o clube, porque as atividades dele (olheiro) são restritamente de observação, o que não garante em nada que o suposto talento diagnosticado por ele tenha sucesso; o clube avalia o atleta em diversos aspectos.

Ainda em relação ao contexto de seleção e formação, observa-se que os meninos préselecionados são encaminhados ao clube a partir dos 12 anos de idade, antes disto os núcleos se encarregam deles por meio da prática de oportunização motora que abrange as idades de 7 a 12 anos.

Os gestores administrativos afirmam que o departamento de futebol é encarado como uma empresa, cuja função é gerar produtos de qualidade que serão negociados (vendidos). A exemplo disto, destacam-se os jogadores que foram vendidos ao exterior (Holanda, Inglaterra etc.), sendo que a maioria dos atletas formados pelo CAP originaram-se dos núcleos.

A partir do momento em que o atleta é aprovado nos testes, é encaminhado para a escolinha na categoria infantil, passando a viver dentro do clube, que oferece uma formação escolar e esportiva sob a supervisão de profissionais que irão acompanhar toda a formação: intelectual, social e esportiva deste atleta.

O clube tem disponível todo um sistema que oferece assistência de nutrição, fisioterapia, odontologia, medicina, biomecânica, com avaliações periódicas, por meio de todo um planejamento realizado de treinamento.

\subsubsection{As fases de formação de jogador}

Conforme descrito anteriormente, o processo de formação do CAP é composto por diversas fases, sendo que a idade mínima para participar é de 12 anos e a máxima de 16. De acordo com os gestores,

[...] as experiências têm demonstrado que trazer atletas com idade superior a esta do processo de formação, para serem avaliados não é bom, [porque] seríamos incoerentes, pois os atletas chegaram no clube aos 12 anos, passaram por um processo rigoroso e foram aprovados. Logo, eles terão que ascender no clube. (Gestores Esportivos) 
Note-se que não respeitar a política e o processo de formação torna-se algo contraproducente ao grupo em formação, pois encaixar um atleta no meio do processo, ou seja, nas fases juvenil e juniores, desmotiva os atletas que iniciaram o processo aos 12 anos e que, depois de aprovados na categoria infantil, esperam passar pelo juvenil e depois para os juniores e finalmente jogar no profissional.

Os gestores do clube têm recomendado aos núcleos e olheiros que encaminhem atletas de no máximo 16 anos de idade, pois

[...] os meninos que chegam no clube acima dessa idade não conseguem de imediato encaixar nas suas respectivas categorias, e sim em categorias inferiores, e levam algum tempo para se enquadrar nas categorias de suas idades. (Gestores Esportivos)

Em observação junto ao processo físico-operacional, podem-se constatar as seguintes fases do processo de formação:

- $\quad 1^{\mathrm{a}}$ FASE - infantil de 12 a 14 anos;

- $\quad 2^{\mathrm{a}}$ FASE - juvenil de 14 a 16 anos;

- $\quad 3^{\mathrm{a}}$ FASE - juniores de 16 a 18 anos.

O diretor científico ressalta que existem meninos com idade inferior "pré-infantil" que atualmente estão no infantil, pois, embora não tenham a idade, estão nesse grupo infantil devido ao seu talento.

No que diz respeito ao número de meninos e a probabilidade de ascensão às outras categorias ou fases citadas anteriormente referentes ao processo de formação, destaca-se que, pela experiência e pelos registros e estatísticas do departamento científico de futebol, se pode então afirmar: na primeira fase - infantil entram em média 100 meninos por período ou por ano, e em média apenas 50\% dos atletas conseguem chegar à fase do juvenil e, desta fase para os juniores, em média $60 \%$.

De acordo com os apontamentos do gestor científico de futebol, nestes 3 últimos anos o clube conseguiu transformar aproximadamente $50 \%$ dos juniores em profissionais. Sendo que dos 32 jogadores profissionais da equipe principal 15 são frutos da categoria dos juniores formados pelo clube. 


\subsubsection{Pirâmide de formação}

Diante das observações e análises das fases e categorias, elaborou-se uma figura em forma de pirâmide para ilustrar o processo de seleção na ascensão das categorias.

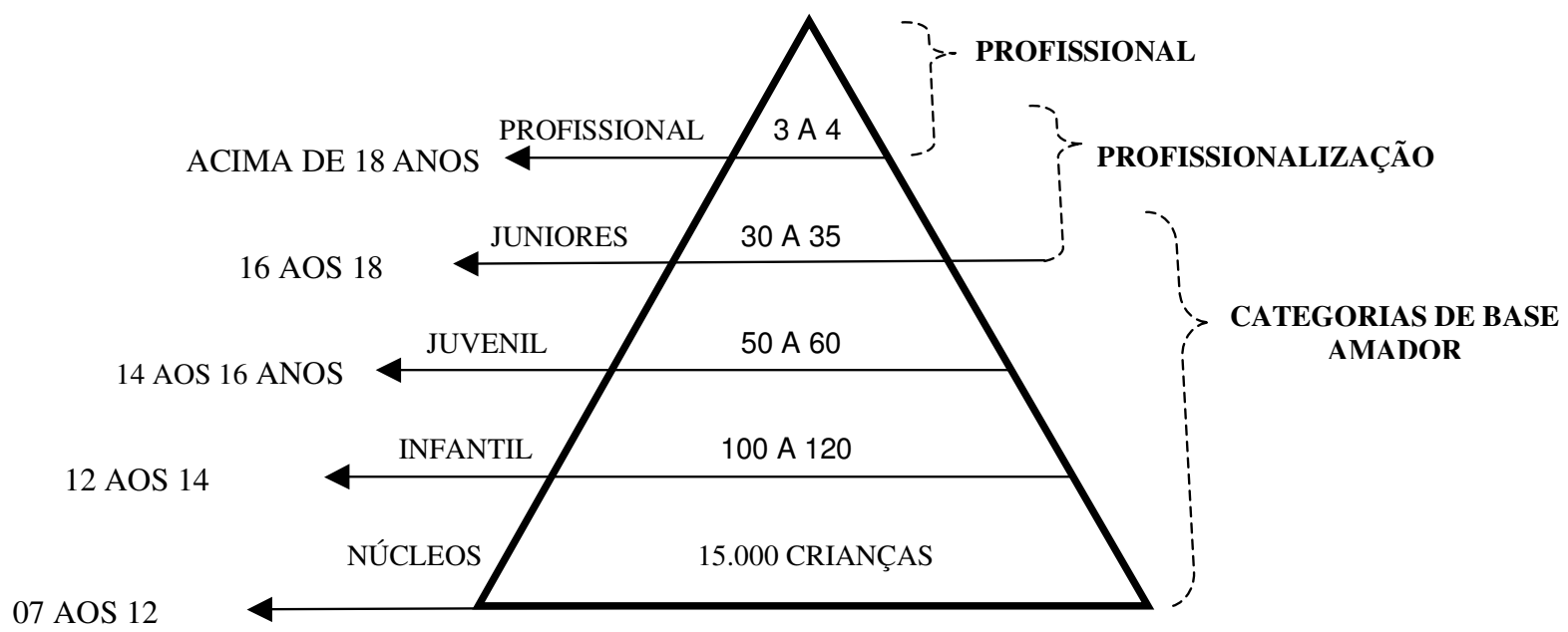

Figura 7 - A pirâmide de formação

Para que seja descoberto um talento é necessário um número muito grande de pessoas praticando o futebol. Desta forma, os gestores dizem que

[...] as escolinhas deveriam ter aproximadamente 100.000 praticantes, para que pudéssemos ter um número maior de atletas, é o que chamamos de oportunização. (Gestores Esportivos)

Verifica-se que, até a fase de juniores, apenas $50 \%$ dos jogadores em média conseguem ascensão à equipe principal. No entanto, a ascensão para o profissional é mais difícil. Os gestores explicam que

[...] existe uma limitação em termos de vaga na equipe principal. Deste modo, não se consegue colocar todos os 30 ou 35 atletas formados pelos juniores no profissional. Só consigo 1, 2, 3 ou nenhum. (Gestores Esportivos)

Os gestores justificam que 
[...] o fato de não conseguir encaixá-los na equipe principal naquele período não quer dizer que não são meninos bons, pelo contrário, tendo em vista o processo de formação ser tão rigoroso. Então, é neste momento que emprestamos os atletas a diversos clubes da segunda divisão de maneira que nestes clubes os atletas vão se aperfeiçoamento e paulatinamente vão retornando ao clube conforme a necessidade. (Gestores Esportivos)

\subsubsection{Clube como uma indústria de formação de jogadores}

O departamento de formação é visto no clube como uma indústria que almeja produzir produtos de qualidade que atendam tanto as necessidades internas como o mercado de jogadores. Os gestores afirmam:

[...] somos vistos como uma indústria de formação de jogadores que tem como base a formação do homem e depois a do atleta, o clube tem uma preocupação social, pelo fato de ser uma empresa que tem a preocupação em lançar uma marca internacional não só de formação de jogadores, mas uma marca de um produto, uma marca de prestação de serviços. (Gestores Esportivos)

O clube, por participar ativamente do mercado internacional de jogadores, observou que as relações internacionais tratam especificamente sobre negociação de jogadores e convênios (intercâmbio de atletas) com diversos países como Coréia, Croácia, Japão e E. U. A., que têm como finalidade trocar experiências em relação à prática do futebol, sendo que esses clubes enviam seus atletas para aprender futebol.

Dado o relacionamento do Clube Atlético Paranaense com diversos países do mundo, o clube tem uma preocupação muito forte com a formação social, cultural e ética do atleta. A exemplo disto, os gestores esportivos relatam que

[...] os clubes europeus se preocupam muito com a formação do homem.

Como abordado anteriormente, o departamento de formação comporta-se como se fosse uma indústria de atletas, lembrando que existe uma preocupação com a formação do indivíduo. De acordo com o diretor científico de futebol, existe um período médio, porém não existe tempo rígido que determine as mudanças de um atleta de uma categoria para outra (exemplo do infantil para o juvenil). 
Observa que é importante manter o atleta nas suas respectivas categorias, pois, a cada categoria, aplica-se metodologia específica de treinamento aos atletas em formação, para que, assim, possam ter o melhor aproveitamento possível. Os gestores esportivos exemplificam:

[...] quando o atleta é infantil tentamos mantê-lo dentro da categoria do infantil, porque ele é ainda criança. Pois o conteúdo do treinamento é elaborado de acordo com a fase.

Para suprir as necessidades de cada fase, o clube realiza convênios com universidades e traz recreacionistas que, durante duas vezes por semana, proporcionam recreação aos atletas da fase infantil.

Notou-se que os especialistas em desenvolvimento motor trabalham periodicamente desenvolvendo habilidades corporais em diversas modalidades esportivas como vôlei, handebol etc. Estas atividades utilizam as estruturas do clube como quadras, piscinas, quadra de tênis. Nesta fase, o diretor (gestor) científico de futebol afirma que,

[...] além da abordagem do futebol, os atletas têm uma formação genérica, mas quando passam para o juvenil esse percentual já diminui, busca outras habilidades, 'amadurecimento para o futebol'.

O clube tem a preocupação de proporcionar ao atleta viver como uma criança normal, oferecendo atividades de lazer, educação, e a prática do futebol não como uma atividade obrigatória e sim de lazer.

Também se constatou que o clube oferece aos meninos o acompanhamento de uma psicóloga, diuturnamente, a qual aplica questionários, testes com objetivo de conhecer o perfil de cada menino, e assim realizar trabalhos de integração de grupo.

No tocante à questão educacional, existe um acompanhamento rígido por parte do gestor científico de formação dos atletas. Este relata que,

[...] se o menino chegar com duas notas vermelhas, peço que apresente o boletim na minha mesa e aplico a seguinte advertência: se repetir a terceira nota, vai pra casa!

Para tanto, o clube disponibiliza professores que auxiliam nas tarefas com aulas de reforço para as categorias infantil e juvenil, pois o clube acredita que a educação é parte essencial no processo de formação. 
Os gestores esportivos abordam que, na maioria dos clubes brasileiros, os departamentos de formação são comandados por ex-jogadores, e asseveram:

[...] não tenho nada contra ex-jogadores, desde que tenham formação específica para tal. (Gestores Esportivos)

Observa-se um certo cuidado no gerenciamento das atividades de formação, pois envolve aspectos físicos, psicológicos e sociais e, portanto, os profissionais responsáveis devem possuir qualificação adequada para tais procedimentos.

Verificou-se que 95\% dos profissionais do Clube Atlético Paranaense têm formação compatível com as exigências das atividades de formação. Todos os técnicos esportivos (professores) têm formação em educação física, formação esta compatível às exigências. Os gestores esportivos afirmam que

[...] o Atlético é como se fosse a indústria da Coca Cola, onde se precisa de bons químicos na preparação do produto.

Eles acreditam que, se não fossem exigidas estas qualificações características de cada profissional vinculado ao processo de formação, não se garantiria o alto padrão de qualidade do produto colocado no mercado e todo trabalho realizado, em longo prazo, seria em vão. Cada etapa do processo de formação do atleta é fundamental para se alcançar qualidade absoluta do produto final.

Sendo assim, a última fase do processo de formação focaliza a categoria dos juniores - atletas que estão na faixa etária de 16 a 19 anos de idade. Esta fase caracteriza-se como uma fase intermediária do processo de profissionalização do atleta dentro do clube.

É nela que os gestores decidem se o jogador tem possibilidade de despontar ou não na carreira de jogador de futebol, neste momento os gestores orientam os atletas quanto às suas reais possibilidades no mercado futebolístico. De acordo com os gestores é neste momento que se decide se o atleta tem condições ou não de seguir carreira no futebol. Se o atleta não tiver condições, então deve-se aconselhá-lo a ir para a universidade e esquecer o futebol. As perspectivas atuais são as de que os atletas com idade de 17, 18 ou 19 anos de idade devem estar prontos para jogar em qualquer equipe nacional e internacional. 
O futebol está cada vez mais dinâmico em termos de formação de atletas. Abordam os gestores que isto acontece em função da evolução dos fatores fisiológicos, pois

[...] são cada vez mais raros jogadores com idade superior a 35 que continuam atuando.

\subsubsection{A importância do processo científico na formação de atletas}

O processo científico destaca-se como parte essencial na formação dos atletas. Para tanto, a pesquisa diagnosticou que o clube possui escalas de avaliações para o processo de seleção e desenvolvimento das fases de formação dos atletas. A metodologia utilizada pelo CAP foi desenvolvida e fundamentada numa base matemática e estatística que tem como objetivo descobrir e desenvolver novos talentos para o futebol.

De acordo com os gestores esportivos, a metodologia foi desenvolvida com o intuito de resolver a questão "como detectar o talento?" Esta é a questão a ser resolvida. O gestor científico de futebol explica que o futebol foi por muito tempo assessorado por profissionais amadores.

O gestor científico de futebol explica que

[...] o futebol brasileiro vive dentro de um contexto que ainda não está muito entendido [...] existem dois ramos que explicam os fenômenos e a formação do conhecimento, uma é a sabedoria popular e a outra é a ciência acadêmica. Na ciência acadêmica você consegue explicar uma série de questões; enquanto que, na sabedoria popular, é cercado apenas pelos mitos, crenças e os achismos.

Nos últimos anos, os esportes migraram para a prática de alto rendimento. De acordo com o gestor científico, é neste contexto que

[...] a ciência acadêmica oferece suas contribuições, explicando a alimentação do atleta, os movimentos pela biomecânica, explica o funcionamento das fibras musculares pela fisiologia.

Os gestores esportivos afirmam que todas as modalidades esportivas deveriam estar inclusas no ramo da ciência acadêmica, como: vôlei, basquetebol, handebol, natação, ginástica olímpica, todos os esportes coletivos e individuais. No entanto, o que

[...] aconteceu foi que o futebol resolveu criar uma coisa para ele, e acabou ficando sozinho num mundo cercado pela sabedoria popular, onde é mais forte a reza, a crença, a cor do uniforme, a 
grama colocada na costela para tirar a dor. Ou seja, o futebol vive tendo experiências que já foram explicadas pelas ciências acadêmicas. (Gestores Esportivos)

Estas atitudes se justificam pelo fato de as pessoas ligadas ao futebol terem criado uma cultura própria, que também pode ser observada na gestão dos clubes de um modo geral. O gestor argumenta que esta cultura futebolística é que não permitiu aos gestores compreenderem a necessidade de mudanças no futebol, vivendo até então sob orientação da sabedoria popular, sendo que suas decisões deveriam ser sustentadas por uma ciência acadêmica.

O gestor científico de futebol afirma que,

[...] neste momento, o Clube Atlético Paranaense está tentando trazer para o futebol a ciência acadêmica ou o contrário, esse é um processo que estamos vivendo hoje, sendo que o futebol brasileiro vai ainda demorar um pouco, para que haja um reconhecimento das necessidades de mudanças. Pois o futebol precisa de estudos e pesquisas, precisa de 'ciências de gestão' como estes trabalhos que ‘você e nós' estamos realizando.

Estas abordagens foram importantes para proporcionar um entendimento sobre a real situação do futebol brasileiro, ou seja, tudo isso é subsídio para responder como detectar um talento.

Os gestores descrevem que a busca de um talento pela sabedoria popular era realizada sempre por

[...] um experiente no futebol que vê o 'moleque' driblando, e leva o menino para jogar num determinado clube. Mas futebol não é só isso, habilidade motora é apenas uma das variáveis. (Gestores Esportivos)

O diretor científico de futebol salienta que atualmente não basta ter apenas habilidade, pois vender jogador para a Europa é muito mais difícil do que alguns anos atrás, tendo em vista que o número de exigências é muito maior.

Os gestores abordaram que a formação de jogadores deve estar de acordo com as exigências do mercado, não adiantando fazer um produto que atenda somente as necessidades regionais, o mercado de jogadores é muito dinâmico. Por exemplo, os clubes ingleses querem jogadores altos, então,

[...] se o jogador for baixinho e jogar bem, ele resolve apenas um problema nosso, regional, mas não resolve o problema da empresa. (Gestores Esportivos) 
Nota-se que o futebol mundial torna-se cada vez mais exigente. Os gestores que participam das negociações no CAP afirmam que,

[...] se o atleta tem alguma patologia, não interessa para o futebol. (Gestores Esportivos)

Diante deste contexto, verifica-se que os clubes europeus antes de adquirir qualquer atleta buscam primeiramente conhecer toda a vida do atleta numa espécie de "processo de rastreamento". Como exemplo, os gestores citaram

[...] o caso do Kleberson, não bastou para o clube ver o atleta ser Pentacampeão Mundial de Futebol, o clube interessado ficou um ano observando o comportamento e investigando a vida do atleta. (Gestores Esportivos)

Conclui-se, então, que os clubes, antes de contratarem um jogador, observam alguns requisitos como suas origens, condições familiares, nível cultural, antecedentes, comportamento nos clubes onde atuou, comportamento psicológico, além de analisar o histórico da "performance esportiva do atleta", ou seja, o seu currículo.

De maneira semelhante à formação de atletas, pode-se então levantar alguns requisitos observados no processo de negociação e, conseqüentemente, no processo de formação, tais como:

- habilidade motora;

- antropometria (estatura do atleta);

- aspecto emocional;

- condições físicas apresentadas e perspectivas de evolução.

\subsection{Metodologia e parâmetros na avaliação dos eventos ligados à gestão dos atletas profissionais}

No futebol profissional, os gestores abordaram que a metodologia de avaliação esportiva é diferente da metodologia usada para atletas em formação,

[...] pois o atleta já está formado, ou seja, quando ele vem para o clube ele já possui todos os requisitos necessários. (Gestores Esportivos) 
Desse modo, nesta categoria o processo de avaliação consiste em avaliar o rendimento do jogador na temporada. O diretor científico de futebol explica que,

[...] se fossemos contratar o Ricardinho, dentro de sua função, iríamos analisar os números de passes, passes certos, passes errados, vira bem a bola, não vira bem a bola, número de gols marcados, número de contusões, número de cartões amarelos e vermelhos e etc.

Observa-se que o histórico do jogador é fator imprescindível à decisão econômica.

O departamento esportivo do clube mantém uma equipe cuja função é elaborar estatísticas de jogos e da atuação dos atletas nos jogos e na temporada, ou seja, cada jogador tem um banco de dados sobre a sua performance por jogo e por campeonato.

Os gestores afirmam que o clube acompanha o desenvolvimento tanto dos atletas profissionais quanto dos amadores, o diretor científico de futebol salienta:

[...] sabemos tudo, acompanhamos o jogador durante todo o tempo, sabemos quantos gols fez, quantos jogos participou no campeonato, quanto tempo participou em cada jogo, se foi tempo integral, meio tempo ou ficou somente no banco. (Gestores Esportivos)

A avaliação esportiva é parâmetro importante para a contratação, ou seja, as contratações baseiam-se na performance histórica do jogador. Os gestores exemplificam que

[...] um jogador que tinha 60 jogos na temporada, quando você analisa o histórico e constata que dos 60 o atleta atuou somente em 10 jogos, mas marcou 5 gols. Eu contrato por isso ou pelo contexto real. (Gestores Esportivos)

O outro ponto investigado refere-se ao relacionamento entre o atleta e a torcida, considerado de suma importância pelos gestores,

[...] pois não tem como contratar um jogador que não vai se relacionar bem com a torcida ou com os jogadores que compõem o grupo. Uma contratação errada pode estragar todo o ambiente de sua indústria, o exemplo começa no início da formação. Por isso que, no profissional, tem que buscar jogadores que se adeqüem à filosofia do clube, se não você se arrebenta. Assim, se você trouxe e sentiu que o atleta não se adequou, manda embora. (Gestores Esportivos)

A exemplo disto, o departamento esportivo do clube encostou 15 atletas, dentre eles atletas de nome, ou seja, atletas consagrados no futebol. Os atletas que não cumprem a filosofia do clube não lhe interessam. Sendo que o comportamento destes atletas, dentro e/ou fora do campo, segundo os gestores esportivos, pode deteriorar, destruir todo o trabalho realizado 
dentro do clube. Uma alternativa encontrada pelo clube para esta situação foi emprestar a outros clubes o atleta inadequado.

\subsection{5 Áreas, atividades e recursos}

Nos levantamentos realizados junto ao processo físico-operacional, foram identificados as principais áreas, atividades e os recursos consumidos na formação e no treinamento dos atletas. Assim, as áreas de atividades e seus respectivos recursos consumidos nos processos são os seguintes:

- ÁREA ADMINISTRATIVA - tem como objetivo cuidar do funcionamento do centro de treinamento, ou seja, de todo gerenciamento da estrutura do centro de treinamento, toda logística;

- ÁREA DA SAÚDE - tem como finalidade dar suporte à formação e assegurar o bemestar dos atletas, sendo composta por diversas atividades, entre elas: odontologia, apoio de massagens como atividade de massoterapia, fisioterapia, nutrição, psicologia, biomecânica, todos estas atividades trabalham para dar suporte tanto ao futebol profissional quanto ao futebol amador;

- ÁREA EDUCACIONAL - é responsável pela formação social, intelectual esportiva dos atletas do CAP, é neste setor que se encontra a parte de sociologia, cuida do relacionamento social individual e familiar dos atletas; e

- ÁREA TÉCNICA ESPORTIVA - encontra-se juntamente com a área educacional, que responde tanto pela formação intelectual como pela formação esportiva.

A questão educacional no CAP, segundo os gestores,

[...] não é oferecida somente aos jogadores, mas a todos os funcionários, desde o jardineiro, telefonistas, porteiro, todos fazem cursos de inglês. Isto porque, se alguém liga dos Estados Unidos, e a telefonista não sabe responder, eu já perdi. O mercado é dinâmico [...] um outro exemplo se alguém pergunta na portaria em inglês e o porteiro não sabe dar a informação, o clube pode ter acabado de perder um negócio. (Gestores Esportivos)

Observa-se, nesta fala, que o clube é visto como uma empresa cujos resultados dependem da eficiência dos seus recursos humanos. Por esta razão, verifica-se a adoção de uma política educacional que abrange tanto a qualificação dos atletas como a dos funcionários em geral. 
Para isto, oferece cursos de inglês, supletivos e aperfeiçoamento administrativo e técnico, por meio de parcerias com o SENAC e universidades locais.

Os gestores afirmam que

[...] ninguém é obrigado, é apenas sugerido. Porém, quem não se enquadra na filosofia do clube é convidado a se desligar das atividades do clube. (Gestores Esportivos)

Tanto os atletas em formação como os profissionais recebem do clube assistência e acompanhamento necessário, como assistência educacional, alimentar, médica, odontológica, psicológica e esportiva; toda assistência necessária sem custos para os atletas que moram no clube.

No que diz respeito à questão financeira, as categorias: infantil, juvenil e juniores recebem uma ajuda de custo cujo valor varia conforme a categoria:

- $\quad$ Infantil, de R \$ 100,00 por mês;

- Juvenil, de $\mathrm{R} \$ 300,00$ por mês;

- Juniores, de $\mathrm{R} \$ 300,00$ a $\mathrm{R} \$ 700,00$ por mês.

Esta ajuda de custo assemelha-se a uma bolsa pelo período em que o atleta permanecer no processo de formação e tem como objetivo suprir a aquisição de produtos básicos. Deve-se ressaltar que, quando o atleta é promovido a profissional, sua situação financeira é alterada.

Ainda em relação ao processo físico-operacional, constatou-se que o tempo médio de formação não se apresenta de forma rígida, tendo em vista que cada atleta tem um conjunto de características fisiológicas diferentes, ou seja, cada atleta responde aos treinamentos de maneira diferente.

As estatísticas e os apontamentos realizados pelo departamento científico de futebol revelaram que o período de formação do atleta no CAP da fase infantil à dos juniores abrange um período de 6 a 7 anos no mínimo. 


\subsubsection{O gerenciamento da carreira dos atletas}

Em relação ao gerenciamento da carreira do atleta, existe no clube um departamento de marketing e um diretor internacional que trabalham especificamente com esta questão, elaborando os currículos eletrônicos dos jogadores e prestando as

[...] orientações necessárias, tanto em aspectos profissionais como financeiros, sendo que o clube tem convênio com a caixa econômica que oferece cursos sobre aplicações financeiras. (Gestores Administrativos)

No que diz respeito à imagem tanto para o clube como para os atletas, os gestores adotaram uma política em que

[...] a imprensa entra no clube (CT) às 9:45 horas, sendo que às 10:00 horas inicia o treinamento e a imprensa só pode tirar foto e filmar, não deve perturbar o jogador. Somente depois do treino às 11:00 horas que é autorizado à imprensa entrevistar os jogadores. (Gestores Esportivos)

No que se refere às entrevistas concedidas à imprensa, tanto pelos jogadores quanto pelos técnicos, o clube coloca sempre à disposição profissionais que realizam acompanhamento, treinamento e orientação necessária.

São oferecidos aos jogadores cursos que ensinam a falar em público, dentre outros importantes à sua carreira. Os gestores esportivos argumentam que

[...] o jogador e o técnico são os vendedores do produto, se eles não souberem vender o produto podem queimar a imagem do clube.

Nesta fala, percebe-se a preocupação do clube em relação à comunicação entre suas atividades e a imprensa.

Os gestores salientam que é importante que o atleta saiba se expressar bem. Diante desta política, os gestores assumiram que,

[...] nos dias de jogos, eliminou-se a possibilidade de a imprensa entrevistar qualquer um, elaboramos um banco que chamamos de coletiva. Depois do treino, escolhemos 1 ou 2 jogadores, normalmente aqueles jogadores que estão melhor emocionalmente no dia, aquele que foi bem no jogo [...] aqui no Atlético a imprensa não fala com quem ela quer, ela fala com quem nós queremos. (Gestores Esportivos)

Estas são apenas algumas das estratégias adotadas pelo clube para salvaguardar a integridade e o bom funcionamento das atividades do clube e relacionamento com a imprensa. 
No tocante à carreira do atleta, ou seja, o período de vida útil dele, os gestores esportivos não se manifestaram,

[...] é muito cedo para nós falarmos sobre isto.

Constatou-se, então, que o clube ainda está realizando estudos sobre esta questão.

No que diz respeito à exploração de direitos de imagem, os gestores financeiros e administrativos argumentam que, nos contratos do clube com os jogadores contratados, se encontram embutidas cláusulas que estipulam os direitos e o percentual do clube na exploração de imagem.

Vale ressaltar que o clube tem exclusividade somente no que se refere às suas atividades operacionais. A exemplo da exploração deste segmento, o jogador Kaká, ex-jogador do São Paulo Futebol Clube, contratou uma empresa para cuidar exclusivamente de sua imagem. Um outro exemplo, dos valores financeiros ${ }^{35}$ auferidos pelo jogador Ronaldinho decorrentes da exploração de sua imagem, $50 \%$ são repassados ao clube Real Madri. Tudo isto devido ao contrato firmado entre o atleta e o clube, na ocasião da contratação. Observa-se que os atletas têm de cumprir apenas o estipulado em contrato, no entanto, se quiserem contratar empresa para gerenciar sua imagem, o contrato firmado com o clube não os impede.

Os gestores relatam que

[...] fora do clube é outra coisa, por exemplo, a UMBRO não paga para os atletas usarem seus produtos fora do clube. Ela tem exclusividade aqui dentro das atividades do clube. Por exemplo, os atletas podem usar a marca de chuteiras que quiserem, o clube não interfere. (Gestores Administrativos)

\subsubsection{Custos de formação e manutenção de atletas}

No tocante aos custos com a formação de atletas e treinamento, constatou-se que o valor é o mesmo tanto para os atletas amadores quanto para os profissionais. Conforme os relatórios e relatos apresentados pelos gestores, o custo médio de cada atleta atualmente é de

\footnotetext{
${ }^{35}$ Informações disponíveis no site: <www.esportebizz.com.br>, em dezembro de 2003.
} 
aproximadamente $R \$ 25,00$ por dia, sendo que somente a alimentação totaliza $R \$ 15,00$. Esta atividade é terceirizada, pois, segundo os gestores,

[...] não seria possível gerenciar todas as outras atividades e ainda se preocupar em servir 600 alimentações por dia. (Gestores Financeiros)

O centro de treinamento oferece uma estrutura que funciona como hotelaria, abrangendo serviços de hospedagem, manutenção, limpeza e lavanderia, ou seja, diversos serviços à disposição dos atletas. O custo operacional mensal varia de $\mathrm{R} \$ 750$ a $\mathrm{R} \$ 850$ por atleta, tanto para as categorias amadoras, quanto para o profissional. Vale ressaltar que não foram inclusos nestes cálculos os salários dos atletas profissionais, nem a ajuda de custo dos atletas amadores.

\subsubsection{O processo de contratação de jogadores}

Segundo os gestores, existe um programa de contratação,

[...] mas que não dá para ser rígido, pois nós temos uma estrada que não devemos perdê-la de vista, estrada que é sempre utilizar os atletas formados pelo clube. (Gestores Administrativos)

Conclui-se que, tendo em vista a filosofia do clube, o planejamento para contratação de atletas não representa um evento de impacto na gestão do clube, visto que este não tem a política de adquirir atletas e sim formar. Mas nem sempre o processo de formação de atletas do clube consegue atender todas as necessidades internas da entidade.

Os gestores esportivos argumentam que conseguir alta qualidade num processo de formação de atletas demora, pois não se consegue formar 10 atletas de alta qualidade por ano. Deste modo, enquanto isso não acontece, o clube precisa buscar atletas em outros clubes.

Os parâmetros utilizados na venda são extraídos das negociações realizadas no mercado, os gestores abordam que,

[...] tem época que os preços estão inflacionados, um exemplo disto é quando os clubes europeus entram no processo de compra de atletas o que eleva significativamente os preços. (Gestores Administrativos) 
Ainda analisando o que ou quem influencia o valor de mercado dos jogadores, observa-se que é inútil competir com os clubes europeus e asiáticos, devido ao poder econômico-financeiro que possuem.

De acordo com os gestores, os custos não servem como subsídio ao processo de negociação de jogadores, pois

[...] o mercado de jogadores é bem diferente [...] a hora que você quer vender não tem mercado, a hora que você não quer vender tem uma alta procura. (Gestores Administrativos)

Constatou-se que o clube não disponibiliza sistemas e métodos para avaliar suas transações; os gestores administrativos argumentam que seria muito difícil fazer um sistema que funcionasse para as necessidades do processo decisório. Os atletas são vendidos em função das necessidades financeiras do clube e é em torno delas que as decisões de vendas geralmente são tomadas.

Em relação ao processo de contratação, o clube não tem a política de contratar atletas por valores que ultrapassem ou estejam fora de seus padrões financeiros. Os gestores afirmam que toda decisão que se toma depende do que o clube quer resolver, pois em se tratando de contratação de jogadores,

\section{[...] a melhor habilidade custa mais caro. (Gestores Administrativos)}

Nota-se que os melhores jogadores naturalmente custam mais. Tudo depende do investimento que o clube irá realizar e onde ele pretende chegar.

A metodologia de formação de atletas adotada pelo CAP tem demonstrado bons resultados, levando o clube a vender mais atletas do que adquirir, sendo que a comprovação da eficácia do processo de formação pode ser observada pelo desempenho da equipe que participou do campeonato brasileiro de 2001, no qual o clube não possuía jogadores consagrados e mesmo assim conseguiu ser campeão, razão pela qual se privilegia o trabalho em equipe ao invés da contratação de um ou dois craques. 
$\mathrm{Na}$ época em que o Atlético foi campeão, a maioria dos jogadores que participou da conquista do título era fruto do trabalho desenvolvido pelo centro de treinamento e formação de atletas do CAP.

Tendo em vista o número de jogos e de campeonatos estaduais, regionais e nacionais, os gestores concluem que

[...] em um campeonato como o campeonato brasileiro com 46 jogos, não basta ter apenas 15, 20 jogadores. O clube deve possuir no mínimo 32 atletas, ou seja, muitas peças de reposição. (Gestores Esportivos)

\subsubsection{Variáveis relevantes para o processo de contratação}

Dentro do contexto de contratação de jogadores pelo clube, apontam-se as seguintes variáveis: multa rescisória e duração de contrato, habilidade do jogador, a idade e salário do atleta. A multa rescisória consiste no desembolso inicial para liberação do que está atuando em outro clube. Esta variável é apontada pelos gestores como uma das mais relevantes nas decisões de contratação.

Observou-se a necessidade de se realizar uma análise específica para as decisões de contratação, pois, se o clube desembolsa um valor expressivo no ato da contratação referente à multa rescisória, um contrato de curto prazo pode gerar um risco para o clube de perder o atleta na melhor fase e não ser restituído da multa rescisória que foi desembolsada no momento da contratação deste atleta, tendo em vista que, ao final do contrato, o atleta estará livre, podendo transitar para qualquer clube.

Os gestores afirmam que

[...] a melhor opção para o clube é um contrato longo. Por outro lado, se firmamos um contrato longo e o atleta não acerta, não se enquadra, temos que pagar os salários por cinco anos ou demitilo e pagar seus direitos [...] Este negócio é muito complicado, tem que ter muita sensibilidade, pois estas decisões não são tão simples, atualmente, contratamos jogadores com salários mais baixos, tentamos contratar jogadores jovens ainda não consagrados. Deste modo, conseguimos administrar uma questão que se torne viável e vantajosa para ambos os lados. (Gestores Administrativos)

Dentre as variáveis investigadas, verificou-se que, além do tempo de contrato, a habilidade do jogador é uma variável que deve estar implícita na negociação, ou seja, é um pré-requisito. 
Em relação à idade do jogador, os gestores consideram-na bem relevante dentro dos parâmetros do processo de negociação.

Os gestores afirmam que

[...] o primeiro ponto é contratar jogadores jovens, entre 18, 20 até 23 anos. Outro ponto refere-se aos salários a serem pagos, pois os salários devem estar de acordo com a filosofia do clube, pois não vamos contratar um jogador para ganhar R $\$ 150.000,00$. (Gestores Administrativos)

Diante da congruência entre os depoimentos e os documentos analisados de forma objetiva, apontaram-se aspectos importantes na política de contratação de atletas do CAP, que se resumem em:

$\checkmark \quad$ Idade - contratar jogadores jovens com idade entre 20 a 23 anos;

$\checkmark \quad$ Habilidade - é pré-requisito;

$\checkmark \quad$ Salários - a contratação deve estar dentro da filosofia do clube; e

$\checkmark \quad$ Multa Rescisória ou taxa de transferência - o desembolso inicial.

De um modo geral os parâmetros utilizados nas negociações são simplesmente vendas semelhantes ou negociações que apresentam as mesmas características. Para os gestores, o valor negociado no mercado é o principal parâmetro para avaliar o atleta no momento da negociação, sendo que os custos na visão dos gestores não são considerados como parâmetros eficientes nas negociações.

\subsubsection{Processo de negociação de jogadores - venda}

A venda de jogadores há muito tempo representa uma fonte expressiva de recursos financeiros para os clubes brasileiros. No estudo de caso, verificou-se, no modelo de gestão do respectivo clube, a existência de uma política de planejamento que contempla apenas a venda de jogadores, sendo esta prática justificada pelo fato de os custos do clube serem superiores às receitas geradas com atividade de futebol e exploração da marca.

Os gestores administrativos argumentam que

[...] o clube tem que vender pelo menos um jogador por ano 'bem vendido', acima de 3 a 4 milhões de dólares. 
Para isso, o clube realiza um trabalho juntamente com empresários ligados ao futebol, tanto no âmbito nacional quanto internacional.

No tocante às questões temporais, foram averiguados dois pontos: o período da temporada propício para a negociação e a idade ideal para vender os jogadores formados.

Para os gestores,

[...] o momento é sempre no começo da temporada, pois no meio da temporada não é possível inscrever o jogador nos campeonatos. Por exemplo, na Rússia as inscrições se encerram no final de fevereiro e na Europa se encerram por volta do dia 15 de fevereiro. (Gestores Administrativos)

Depois deste período os clubes não conseguem negociar seus jogadores.

No que diz respeito à melhor idade para negociar seus jogadores, eles argumentaram que esta é uma questão extremamente difícil de responder. Mas, mesmo assim, observou-se que existe um período importante que influencia a valorização do jogador nos aspectos financeiros, econômicos e esportivos, este momento é quando o jogador chega à Seleção Brasileira, independentemente da categoria.

Os gestores consideram que a chegada à seleção é o melhor momento, tanto para a carreira do atleta quanto em termos de valorização econômica. Diante deste contexto, os gestores do CAP buscam preparar seus atletas para que possam chegar à seleção, pois,

[...] enquanto não forem para seleção brasileira, o mundo, os clubes do exterior, não vêem o nosso jogador com bons olhos, mesmo que o atleta aqui seja considerado um craque. (Gestores Esportivos)

Destaca-se, então, que os clubes almejam que seus atletas cheguem à seleção brasileira. De acordo com os gestores,

[...] não queremos fazer um produto para o mercado nacional. O mercado nacional só trabalha com empréstimos, o mercado nacional não tem dinheiro para comprar o produto que está sendo produzido aqui. (Gestores Administrativos)

Os gestores expõem que 
[...] a política do clube não é vender os jogadores da categoria de Juniores [...] Como exemplo, no ano de 2003 foram revelados vários jogadores desta categoria, mas não cabem no time principal. Sendo assim o clube não irá vendê-los e sim emprestá-los. (Gestores Esportivos)

Para os gestores esportivos e administrativos, o assédio do mercado é uma variável importante, no entanto, destacam que

[...] uma coisa é o assédio do mercado nacional, outra coisa é assédio do mercado internacional.

Desse modo, segurar o atleta no clube e decidir qual é o momento apropriado para negociá-lo em função do assédio do mercado torna-se uma tarefa difícil e complicada para os gestores envolvidos no processo. Eles argumentam que a parte mais complicada é definir que

[...] momento é o momento de se vender o atleta?

Isto é considerado, pelos gestores, como algo complicado de se resolver, por exemplo,

[...] o clube tem um determinado jogador que todo mundo está interessado. Se o clube vende no meio do campeonato, daqui a pouco o jogador vai lá e arrebenta. Eu deveria ter esperado mais, ou seja, que momento eu vou vender? (Gestores Administrativos)

Observa-se que o momento de negociar os atletas depende exclusivamente do julgamento do gestor em avaliar o potencial econômico do atleta no clube, e assim determinar o momento em que ele será negociado.

Os gestores exemplificam que

[...] as propostas iniciais para o Kleberson eram de 5, 6 milhões, o presidente adotou a política de segurar o atleta até um pico que ele considerou que seria o adequado para o clube.

Mas, os gestores lembram que

[...] se ele jogar meia temporada agora no Manchester, ele vai ser vendido por um valor que não iríamos conseguir colocá-lo no pico (valores) que ele pode atingir no Manchester. (Gestores Administrativos)

Em função do assédio do mercado e as limitações financeiras do clube, torna-se impossível segurar os atletas. Destacam-se estes fatores como importantes no processo de negociação. 
Os gestores relatam que, no caso específico do CAP, tendo que vender no mínimo um jogador por ano, o clube pode soltar um jogador por 10 que valeria 12 ou 13 milhões.

Diante desse contexto, a precifição ou a atribuição de valor aos jogadores é um elemento complexo, tendo em vista a imprevisibilidade e a dinâmica deste mercado. Os gestores argumentam:

[...] Isto é algo muito aleatório. Não existe uma tabela de preços para atacante com idade X, preço para zagueiro Y e etc. (Gestores Administrativos)

Os gestores administrativos afirmam que o ideal seria que existisse uma bolsa, a exemplo dos ingleses que possuem uma bolsa de jogadores. Eles explicam que

[...] o negócio funciona mais ou menos assim, por exemplo, o Fernandinho, aquele atleta que fez o gol na final do mundial sub-17, já recebemos propostas milionárias, com esta qualidade técnica a Europa quer o jogador a qualquer preço. Não interessa se o atleta tem apenas 18 anos.

Os gestores administrativos relatam que os clubes europeus não querem comprar mais jogadores velhos, como exemplo, do Rivaldo e outros. Nestes casos seriam os últimos a serem negociados.

Tendo em vista a ausência de uma metodologia para avaliação das decisões (negociações), constatou-se que os gestores utilizam como parâmetro as negociações efetuadas no mercado, ou seja, avaliam e precificam seus atletas de acordo com operações similares analisando as transações que envolvem outros jogadores que possuem as mesmas características daquele que está sendo negociado.

Para os gestores, este método de avaliação leva em consideração negociações semelhantes, eles afirmam e exemplificam que

[...] esse método é um dos mais utilizados, é o indicador mais visto no mercado. Por exemplo, o jogador Kaká foi vendido por 8 milhões, antes de negociar verificamos outro que joga na mesma posição com a mesma idade. Nós estudamos muito este esquema.

Afirmam ainda os gestores que

[...] nunca iremos vender o Dagoberto pelo mesmo preço que o Kleberson, pois atacante vale mais. (Gestores Administrativos) 


\subsection{6 $O$ valor de mercado do atleta está relacionado com a sua posição em campo}

Nas entrevistas constataram-se elementos importantes no que diz respeito à posição em que o jogador atua e seus respectivos salários e valor de mercado,

[...] atacante sempre vale e ganha mais. (Gestores Administrativos e Esportivos)

Observou-se que o valor comercial do atleta está relacionado com a posição em campo. Os gestores administrativos e esportivos explicam que

[...] o mercado reconhece uma hierarquia, onde a zagueirada ${ }^{36}$ é quem ganha menos, goleiro menos ainda, atacante e meio atacante são os que mais ganham, depois volante.

Observa-se que existem algumas exceções, como exemplo o jogador Gamara ex-zagueiro do Corinthians, o jogador Marcos, goleiro do Palmeiras, sendo que esses casos fogem à regra.

Os gestores apontam que

[...] o caso do jogador Alex do Cruzeiro, que atua na posição de meia atacante. Um jogador que exerce uma típica, onde ele viabiliza o gol do atacante e também faz gols. Provavelmente, hoje se pode dizer que depois do Rivaldo é o maior salário recebido por um jogador num clube brasileiro. (Gestores Esportivos)

Diante dos relatos, conclui-se que:

1. Atacante - maiores salários e maior valor de mercado;

2. Meia-atacante - maiores salários e valor inferior em relação ao atacante;

3. Volante - menores salários e valor inferior em relação ao meia-atacante;

4. Zagueiro - menores salários valor inferior em relação ao volante;

5. Goleiro - menores salários e menor valor de mercado.

Estas constatações foram unânimes entre os gestores entrevistados ligados a vários segmentos do clube; administrativo, financeiro e esportivo. Verificou-se ainda que também nos registros

\footnotetext{
${ }^{36}$ Segundo o Dicionário Michaelis (versão eletrônica Dic Michaelis Uol), e livros sobre assuntos esportivos: Zagueiro é o beque, jogador que atua na parte defensiva do time, tem a função de defender o time contra os ataques do time adversário, e o termo zagueirada é uma definição utilizada para definir um conjunto de zagueiros, que inclui os jogadores que atuam na posição de Quarto-zagueiro - 4 , Zagueiro - 3, Lateral - 2, os respectivos números indicam normalmente a posição e função em campo.
} 
históricos do futebol, os salários exorbitantes ${ }^{37}$ são pagos aos jogadores de acordo com a sua posição em campo. Cita-se como exemplo os jogadores Ronaldinho - atacante, Rivaldo meia-atacante, Zidane - atacante.

Deve-se ressaltar que os valores são maiores tanto em termos de salários quanto de multas rescisórias para os atacantes e meia-atacantes, pois o valor dessa multa em sua maioria é calculado sobre o valor do salário pago ao atleta. A legislação brasileira estabelece que o valor da multa rescisória não pode ultrapassar 100 vezes o valor do salário pago ao atleta.

\subsubsection{Decisão de empréstimos de jogadores}

A respeito das decisões relacionadas a empréstimos de atletas, o clube tem uma política de emprestar tanto atletas formados como atletas na fase de juniores. Afirmam os gestores esportivos que

[...] a equipe principal não tem vagas para todos.

O fato de o clube emprestar o atleta que se encontra na fase de juniores não quer dizer que ele não serve para o clube.

Os gestores esportivos abordam que

[...] não estão vendendo, mas apenas emprestando. Isto acontece especificamente pelo fato de não ter vaga na equipe principal para todos os atletas formados.

O clube empresta os atletas juniores para as equipes da segunda divisão. Deste modo, os atletas ganham experiência jogando como titulares no profissional. Ao poucos o Atlético os traz para jogar na equipe profissional. Este estágio serve como forma de mostrar o futebol dos atletas formados no CAP ao mercado internacional.

Os gestores administrativos ressaltam que o mercado nacional atualmente só trabalha com empréstimos, pois é

\footnotetext{
${ }^{37}$ Estas informações podem ser vistas nos site dos clubes europeus, onde são divulgados os salários e os valores das suas respectivas multas rescisórias.
} 
[...] muito raro ouvir falar que o Flamengo comprou jogador do Corinthians. Temos como exemplo o jogador Alex Mineiro emprestado ao Clube Atlético Mineiro por um valor de, aproximadamente, $\mathrm{R} \$$ 400.000. No entanto, o CAP não quer vendê-lo. Sendo assim colocou um multa rescisória de 5 milhões de dólares.

As decisões de empréstimos também acontecem por outras razões. Como exemplo, o atleta que não se adequar à filosofia do clube, principalmente no aspecto disciplinar, seja dentro ou fora do clube,

[...] o clube não consegue negociá-lo (vendê-los), então os empresta para outros clubes. (Gestores Esportivos)

O empréstimo é considerado pelos gestores esportivos do clube como boa alternativa, tendo em vista a situação financeira dos clubes brasileiros. Afirmam que, hoje em dia, esta prática vem sendo muito utilizada tanto pelos clubes nacionais como internacionais.

Ainda em relação ao empréstimo, destaca-se um outro aspecto importante que é utilizar-se desta operação como meio de divulgar o atleta da casa, uma vez que este, ao atuar em clubes de maior expressão, adquire maiores chances de tornar-se reconhecido tanto pelo público torcedor quanto pelo mercado nacional e internacional. Os gestores, então, entendem este procedimento como uma excelente estratégia de marketing para conseguir melhores preços em negociações futuras.

A exemplo disto, os gestores reportam-se ao caso do jogador Fabiano que está atuando no São Paulo Futebol Clube. Eles acreditam que, quanto maior o clube, melhor a vitrine ao futebol mundial, no que diz respeito ao acompanhamento sobre o desempenho do atleta.

Diante das convergências dos depoimentos, observações e relatos, conclui-se que cada vez mais o CAP

[...] tem buscado jogadores que se adeqüem à filosofia do clube, pois, se não for assim, o clube arrebenta todo trabalho feito pelo departamento de formação. (Gestores Esportivos)

Uma outra ação alternativa é aquisição parcial, em que se adquire 50\% do passe dos jogadores de outros clubes que ainda estão em formação. Os gestores administrativos exemplificam que,

[...] no caso do goleiro Diego do clube Juventude, o CAP pagou apenas 1 milhão, o que corresponde a $50 \%$ passe. [...] este atleta foi considerado pelos técnicos esportivos como melhor goleiro do campeonato brasileiro de 2002, o clube adquiriu o referido atleta parceladamente, o que 
justifica a situação financeira do clube. Pagamos 300 mil, depois 100 mil e adquirimos apenas uma parte.

Outro ponto discutido com os gestores refere-se ao tempo de empréstimo, que atualmente é no máximo por uma temporada de um ano. No momento em que o clube retoma um jogador, sobe a condição de empréstimo, neste caso, a variável salário é importante, pois, em alguns casos, os clubes emprestam os atletas em troca dos salários.

Os gestores explicam que

[...] o clube empresta o jogador, pelo fato do jogador estar há muito tempo no clube, pois a cada renovação de contrato o salário do atleta fica muito alto, sendo que na maioria das vezes os clubes emprestam o jogador de graça, só pelo compromisso de assumirem salário do jogador. (Gestores Administrativos)

As decisões de empréstimos de jogadores suprem a falta de recursos em que se encontram os clubes brasileiros. Esses empréstimos têm caráter político importante, pois estabelecem e fortalecem o relacionamento entre os clubes, uma vez que eles se ajudam mutuamente, pois é a partir do "jogo", da disputa entre as equipes e de seus atores, que o futebol demonstra a sua razão de ser.

\subsubsection{A decisão - permuta de jogadores}

As decisões de permuta representam um número muito pequeno em relação ao número de vendas, contratações, compras e empréstimos. De acordo com os gestores administrativos, este tipo de evento não envolve valores monetários, baseia-se estritamente na troca: "vai o jogador A e vem o jogador B”. Os gestores do clube não realizam análises econômicas. Apenas a questão salarial é levada em consideração, deve-se lembrar que as análises esportivas estão presentes em todos os eventos, sendo averiguado junto ao departamento se os atletas em negociação têm utilidade ao contexto esportivo do clube.

\subsubsection{Contratos e renegociações de contratos}

O processo de negociação dos contratos representa o momento em que se estabelecem os pesos e as medidas, ou seja, estabelecem direitos e obrigações entre as partes na 
materialização dos desejos comuns. No processo de renegociação não é diferente, já que toda negociação ou renegociação acertada gera um novo contrato.

Os contratos firmados no cenário do futebol (clube - atleta) têm início no término da formação ou na primeira contratação do atleta pelo clube, uma vez que, ao final da vigência do contrato, o clube decide se continua ou não com aquele atleta considerando as possibilidades de retornos econômicos, financeiros e operacionais, caso haja a renovação.

Sabe-se apenas por observações que o retorno esportivo (atleta) é muito incerto, tendo em vista que este pode se machucar na primeira partida, não se adaptar ao grupo, ao ambiente ou, na pior das hipóteses, até morrer de infarto no dia seguinte.

A exemplo disto, os gestores exemplificam o caso do jogador Adriano. O clube conseguiu vendê-lo por um bom preço para um clube francês, mas em menos de um ano o atleta voltou, pois não se adaptou ao lugar.

No estudo de caso, verificou-se que o momento de renegociação de contratos acontece em média entre 2 a 3 (excepcionalmente até 6 meses) antes do final. Um ponto investigado refere-se à questão de valorização em relação à renovação do contrato. Os gestores abordaram que,

[...] se o atleta tiver um contrato de 4 a 5 anos, não traz implicações, pois, normalmente a renovação acontece de fato no final do contrato. (Gestores Administrativos)

A questão da lei do passe e suas implicações junto ao clube no que tange à renegociação de contratos é outro ponto que foi investigado. Os gestores administrativos responderam que as maiores implicações foram em relação aos atletas que pertencem ao período de formação,

[...] pois, o clube acaba tendo que profissionalizar o atleta muito cedo. (Gestores Administrativos)

Se o jogador entra aos 12 anos, aos 17 já está profissionalizado e, se ele quiser, vai embora.

Os clubes buscam alternativas para diminuir seus riscos nas transações de jogadores ao firmarem contratos cujas cláusulas garantem multas rescisórias, uma alternativa encontrada 
para assegurar que o investimento realizado não se perca, tendo em vista a natureza incerta do investimento.

Assim, o clube (principal) garante, através do contrato, mesmo que por tempo determinado, o direito e o uso exclusivo dos serviços do jogador contratado e, na outra vertente, o jogador (agente) tem assegurada uma remuneração mensal, além de gratificações e prêmios, de forma líquida e certa, durante período predeterminado.

Com o objetivo de entender e compreender alguns aspectos econômicos do processo de negociação entre clube-atleta, o estudo procurou investigar o momento em que os clubes fecham o primeiro contrato com os jogadores formados nas categorias de base.

Segundos os gestores,

[...] o primeiro contrato é uma decisão que deve ser muito bem pensada. Porque o primeiro contrato é de cinco anos, se o clube profissionaliza o atleta com 12 anos de idade quando ele chegar aos 17 anos ele está de passe livre. (Gestores Administrativos)

Na fase em que o atleta é amador, o clube costuma profissionalizá-lo o mais tarde possível,

[...] segurá-los o quanto pudermos nas categorias de base. (Gestores Administrativos)

Deste modo, o clube garante um período de 18 a 23 anos para negociá-lo, e assim obter uma valorização econômica do jogador, ou seja, o direito federativo. O clube utiliza-se de mecanismos legais para resguardar seus direitos de formação e no futuro poder negociar este atleta. Para isto, o clube registra os atletas como funcionários em carteira profissional, com exceção dos jogadores menores de 16 anos que não podem ser registrados, mas continuam por terem consciência das dificuldades do mercado futebolístico,

[...] eles não vão embora, porque eles sabem da situação caótica do futebol brasileiro. (Gestores Administrativos)

Além disto, o diretor científico de futebol argumenta que os atletas permanecem por saberem que o clube tem como filosofia priorizar os atletas da casa. Caso não haja vaga para todos, a qualificação oferecida os deixará preparados para atuar na equipe profissional de qualquer outro clube, 
[...] porque os atletas sabem que aqui a política do clube é jogar no profissional. Enquanto que nos outros clubes não. Pois a equipe profissional dos outros clubes está sempre contratando outros atletas. Tendo em vista a nossa formação ser muito forte, o atleta sabe que aqui ele vai jogar no profissional. Nós criamos uma cultura para que eles não vão embora. (Gestores Esportivos)

Quanto à renegociação do contrato, de um modo geral, as principais variáveis apontadas são o rendimento e a disciplina do atleta, os gestores argumentam que

[...] somos uma empresa que vê resultado. Primeiro temos que verificar qual foi o rendimento do atleta, se ele está aqui dentro e existe o interesse em ambas as partes em renegociar a sua permanência. Ou seja, as outras variáveis estão bem, ele é um atleta comportado, treina bem, ele não traz problemas para nós, ou seja, compensa ficar com ele. (Gestores Administrativos)

A renovação depende das intenções do clube, desta forma os gestores exemplificam com o caso do jogador Fabiano que atuava no CAP,

[...] Fabiano, lateral esquerdo, considerado um jogador espetacular, no entanto, chegou um momento que as propostas que estávamos recebendo não alcançavam o valor desejado,. Renovamos o contrato e emprestamos o jogador ao São Paulo Futebol Clube. Ou seja, precisamos colocá-lo num lugar que o projetasse melhor do que o CAP. Eles assumiram o salário e receberam um percentual sobre qualquer negociação futura. (Gestores Administrativos)

\subsubsection{Remuneração e prêmios dos atletas profissionais e amadores}

Os atletas profissionais recebem salário mensal e todas as gratificações e vantagens de acordo com a Legislação Trabalhista vigente. Existem duas modalidades de prêmios, por jogos e por finalizações de campeonatos, que são concedidos aos atletas.

O prêmio por jogo é denominado como "bicho", em que o clube paga determinada quantia pelas vitórias aos jogadores, atualmente existe um pacote de oito jogos por mês. O valor do prêmio é de $R \$ 300,00$ pela vitória aos atletas que participam de toda a partida, $R \$ 150,00$ para os atletas que participam apenas metade do tempo e $\mathrm{R} \$ 100,00$ para os que ficam no banco. Os gestores esclarecem que somente os 18 atletas inscritos para o jogo recebem.

No que diz respeito à premiação por finalização de campeonato, a política do clube é oferecer estímulos financeiros pelas conquistas, citando como exemplo os campeonatos estaduais, campeonatos regionais "Sul-Minas" e campeonatos nacionais. Além dos salários e prêmios, os atletas recebem uma remuneração que corresponde aos direitos de imagem dos jogos televisionados. 
O direito de arena está vinculado aos repasses da TV, no entanto não traz impacto nas finanças dos clubes, uma vez que todos os clubes têm de repassar a cota referente à participação dos atletas nos respectivos campeonatos.

Outro ponto muito explorado pelos clubes no exterior é o direito de imagem dos atletas. Podese citar o caso do Ronaldinho, que faturou aproximadamente ${ }^{38} 10$ milhões de dólares com contratos de publicidade pelo uso de sua imagem, e o clube ao qual se encontra vinculado levou $50 \%$ de todo valor auferido pelo jogador, além do faturamento com a venda da "camisa número 9".

Tendo em vista que os salários dos jogadores representam um dos maiores custos operacionais, o clube estabeleceu uma política salarial com limites que viabiliza o cumprimento de suas metas:

$1^{\mathrm{a}}$. Faixa de R\$1.000,00 a 10.000,00;

$2^{\mathrm{a}}$. Faixa de $\mathrm{R} \$ 10.000,00$ a $20.000,00 ;$

$3^{\mathrm{a}}$. Faixa de R\$20.000,00 a 30.000,00;

$4^{\mathrm{a}}$. Faixa de $\mathrm{R} \$ 30.000,00$ a 60.000,00.

Deste modo, os gestores do clube executam suas atividades dentro de um orçamento preestabelecido ao período. Os gestores administrativos apontam que a adoção de uma política salarial impõe limites. Deste modo, os gestores não perdem a linha. No final, tem-se uma folha de pagamentos que não pode ultrapassar $\mathrm{R} \$ 1.000 .000,00$ por mês.

Os gestores ressaltam que a política financeira adotada está contribuindo para a boa gestão do clube. Lembrando que os jogadores amadores não têm remuneração e sim uma ajuda de custo mensal, que não se caracteriza como salário.

\subsection{Interpretação dos dados}

\footnotetext{
${ }^{38}$ Informações obtidas no site: <www.esportebizz.com.br>, em dezembro de 2003.
} 
O estudo de caso, resguardadas as suas limitações e as características de um estudo exploratório, possibilitou um importante entendimento sobre o processo de identificação dos parâmetros da avaliação do jogador de futebol.

Os fenômenos ligados às decisões econômicas com jogadores de futebol apresentam um campo pouco explorado pela ciência contábil. Os gestores lamentam a ausência de estudos haja vista a imprevisibilidade, subjetividade e dinâmica deste mercado e o contexto onde estas decisões acontecem.

\subsubsection{O processo de negociação de jogadores e o contexto dos eventos}

Os eventos ligados à negociação de jogadores identificados no estudo de caso são descritos como: formação, venda, compra, empréstimo, permuta e renegociação. Cada evento mencionado representa uma decisão econômica e envolve variáveis específicas que impactam o resultado do clube.

Estes eventos surgem durante a carreira dos atletas em qualquer período, com exceção do evento formação que se caracteriza como evento decorrente do período em que o atleta não é profissional.

Deve-se ressaltar que estes eventos são alicerçados por contratos e, na maioria das vezes, os contratos são renegociados. Conforme argumentam os gestores, a renegociação de contrato é considerada uma tarefa complexa, pois envolve conflitos de interesses e a performance do atleta é um fator relevante neste processo de negociação.

\subsubsection{Caracterização dos eventos}

Os eventos distinguem-se como decisões econômicas que estão relacionadas às fases de formação, permuta e renegociações, consideradas como decisão exclusiva da fase profissional, como pode ser visto na figura a seguir: 


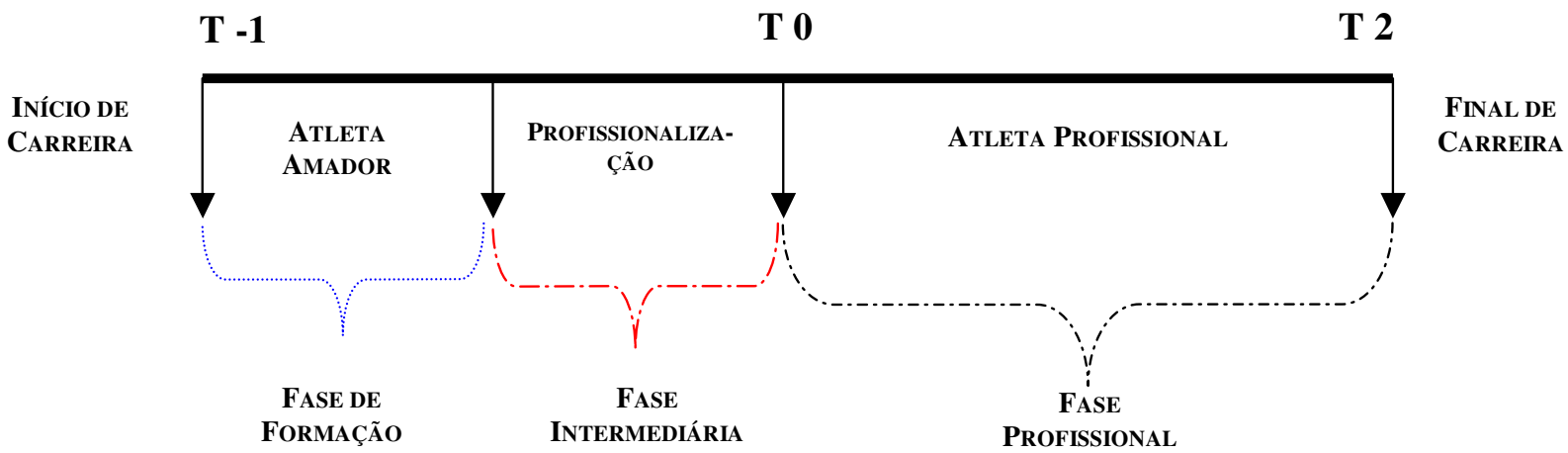

Figura 8 - As fases da carreira de um atleta

De acordo com as evidências encontradas pelo estudo, a carreira de um atleta inicia-se aos 12 anos (infantil) e vai até 36 anos aproximadamente, sendo que a legislação desportiva brasileira estabelece idade mínima tanto no âmbito do futebol amador como do futebol profissional. A carreira esportiva do atleta de futebol é formada por diversas fases que vão da formação ao profissional.

Os investimentos feitos pelo clube em atletas no período de formação geram direitos ao clube formador de negociá-los no futuro. Este vínculo é chamado de direitos federativos, ou seja, contratos por tempo determinado e preferências na renovação de contrato ao clube formador.

A pesquisa identificou que existem as seguintes decisões ou eventos ligados ao processo de negociação de jogadores de futebol, e aponta a finalidade de cada evento:

- DECISÃO DE FORMAÇÃO - atender a demanda interna e externa;

- DECISÃO DE CONTRATAR OU COMPRAR - necessidades operacionais (reposição) ou expectativas econômicas futuras (valorização); 
- DECISÕES DE VENDER - limitações financeiras, oportunidades (valor de mercado > valor econômico) ou o atleta não se enquadra na filosofia do clube;

- DECISÕES DE EMPRESTAR ${ }^{39}$ - limitações da equipe principal, fortalecer relacionamento entre os clubes, atleta que não se enquadra na filosofia do clube;

- DECISÕES DE PERMUTAR - decorrente de interesses entre as partes;

- DECISÕES DE RENEGOCIAÇÃO DOS CONTRATOS - a existência de interesses entre as partes.

A renegociação de contratos é um tipo de decisão ou evento considerado como decisão subseqüente às decisões de formar, comprar e emprestar, pois estes eventos podem constituir oportunidades e ameaças ao futuro do clube e dos atletas.

Esta fase da pesquisa foi importante na identificação dos eventos e variáveis que subsidiarão a estruturação dos modelos de identificação, mensuração e decisão, conforme quadro a seguir.

${ }^{39} \mathrm{O}$ clube tem uma política forte de empréstimo de atletas, tendo em vista que a equipe principal não consegue absorver todos os atletas formados pelas categorias de base, e o clube não tem a política de negociar atletas nesta fase. Este evento caracteriza-se como uma estratégia para fortalecer o relacionamento entre os clubes. 
Quadro 1 - Eventos e variáveis

\begin{tabular}{|c|c|c|}
\hline EVENTOS & FINALIDADES & PRINCIPAIS VARIÁVEIS \\
\hline - $\quad$ FORMAÇÃO & $\begin{array}{l}\text { Atender demanda } \\
\text { interna e externa. }\end{array}$ & $\begin{array}{l}\text { 1. } \quad \text { Quantidade de praticantes (oportunização motora); } \\
\text { 2. Processo de seleção; } \\
\text { 3. } \\
\text { 4. } \\
\text { Custodologia de treinamento e formaçãão. }\end{array}$ \\
\hline - COMPRA & $\begin{array}{l}\text { Necessidades } \\
\text { operacionais } \\
\text { (reposição), ou } \\
\text { expectativas } \\
\text { econômicas } \\
\text { futuras } \\
\text { (valorização). }\end{array}$ & $\begin{array}{l}\text { 1. Contratar jogadores jovens com idade entre } 20 \text { a } 23 \\
\text { anos - Idade; } \\
\text { 2. Habilidade é pré-requisito - Habilidade; } \\
\text { 3. A contratação deve estar dentro da filosofia do clube } \\
\text { - Salários; } \\
\text { 4. Desembolso inicial - Multa Rescisória ou taxa de } \\
\text { transferência. }\end{array}$ \\
\hline - $\quad$ VENDA & $\begin{array}{l}\text { Limitações } \\
\text { financeiras, } \\
\text { oportunidades } \\
\text { (valor de mercado } \\
\text { maior ralor } \\
\text { econômico), ou } \\
\text { atleta não } \\
\text { enquadra } \\
\text { filosofia do clube. }\end{array}$ & $\begin{array}{l}\text { 1. O momento de negociar os atletas depende } \\
\text { exclusivamente do julgamento do gestor em avaliar o } \\
\text { potencial econômico do atleta no clube; } \\
\text { 2. As vendas acontecem no início dos campeonatos; } \\
\text { 3. Limitações financeiras; } \\
\text { 4. A metodologia utilizada para avaliar e precificar as } \\
\text { suas negociações - são comparações entre jogadores } \\
\text { semelhantes, com a mesma idade, mesmas posições, } \\
\text { foram vendidos por este preço; } \\
\text { 5. Os jogadores são vendidos após a fase de juniores } \\
\text { (normalmente). }\end{array}$ \\
\hline - EMPRÉSTIMO & $\begin{array}{l}\text { Limitações da } \\
\text { equipe principal, } \\
\text { fortalecer } \\
\text { relacionamento } \\
\text { entre os clubes, } \\
\text { atleta que não se } \\
\text { enquadra na } \\
\text { filosofia do clube; }\end{array}$ & $\begin{array}{l}\text { 1. Capacidade de absorver todos os atletas formados; } \\
\text { 2. Comportamento extra-campo; } \\
\text { 3. O atleta que não se adequar à filosofia do clube; } \\
\text { 4. Quando o clube não consegue negociá-lo, vendê-lo; } \\
\text { 5. Boa alternativa financeira. }\end{array}$ \\
\hline - $\quad$ PERMUTA & $\begin{array}{l}\text { Decorrente de } \\
\text { interesses entre as } \\
\text { partes; }\end{array}$ & $\begin{array}{l}\text { 1. } \text { Questão salarial; } \\
\text { 2. Análises esportivas; } \\
\text { 3. } \quad \text { O atleta tem utilidade ao contexto esportivo do clube. }\end{array}$ \\
\hline $\begin{array}{ll}- & \text { RENEGOCIAÇÃO DE } \\
\text { CONTRATOS }\end{array}$ & $\begin{array}{l}\text { Existência de } \\
\text { interesses entre as } \\
\text { partes. }\end{array}$ & $\begin{array}{l}\text { 1. A renegociação de contratos acontece em média } 2 \text { a } 3 \\
\text { meses antes do fim do contrato; } \\
\text { 2. Primeiro contrato de } 18 \text { a } 23 \text { anos; } \\
\text { 3. Idade; } \\
\text { 4. Salários; } \\
\text { 5. Performance na temporada. }\end{array}$ \\
\hline
\end{tabular}

Resumindo, as principais evidências do estudo de caso, apontadas no quadro, referem-se à classificação dos eventos identificados, suas justificativas e principais variáveis, o que será objeto de estudo no próximo capítulo. 


\section{MODELOS DE DECISÃO DOS EVENTOS ECONÔMICOS IDENTIFICADOS NA GESTÃO DE CONTRATOS DE JOGADORES DE FUTEBOL}

Este capítulo tem como objetivo estruturar os modelos de decisão dos eventos identificados à gestão de jogadores de futebol, apontados a partir do estudo de caso. São, assim, estruturados o modelo de identificação, de mensuração e de decisão de cada evento identificado no referido estudo de caso.

Tendo em vista os objetivos da pesquisa, os modelos propostos têm como meta principal orientar os gestores em suas decisões considerando o impacto econômico de cada evento.

\subsection{O contexto das transações e eventos}

O futebol é constituído por relacionamentos que formam a estrutura básica dos negócios ligados ao esporte. Leoncini (2001) aponta três tipos básicos de relacionamentos com clientes que formam a base da estrutura de negócios na qual se enquadram os vários relacionamentos:

- O primeiro refere-se ao valor da marca ou do campeonato, considerado por Taylor (1998) como "patrimônio dos fãs".

- O segundo tipo trata de um relacionamento com os consumidores intermediários (TV, mídia, empresas de licenciamentos e interessados no marketing esportivo).

- É no terceiro relacionamento que se encontram as entidades como os clubes, as federações e as ligas.

São oriundas do terceiro relacionamento as negociações de jogadores, consideradas a principal fonte de recursos financeiros dos clubes brasileiros. Ao mesmo tempo em que os jogadores representam os principais agentes para o negócio, são também o produto de maior valor para o clube. É neste contexto que se caracteriza a existência de um mercado ativo, onde se compra, vende, empresta e permuta jogadores. Delineado, desta forma, o contexto de negociação de jogadores, parte-se para a conceituação das transações e eventos vinculados a este ativo. 
Os clubes realizam diversas transações durante os campeonatos e temporadas: comprando, vendendo, emprestando, renegociando contratos e até mesmo permutando atletas. Estes eventos movimentam altas quantias no mundo esportivo "futebol".

Hendriksen (1999, p. 89) define que

[...] um evento é uma ocorrência, um fenômeno ou uma transação, o qual é separado para ser observado e ter uma melhor interpretação semântica do que a mensuração de ativos e passivos. No entanto, somente certas características dos eventos podem ser mensuradas e reportadas; na abordagem contábil do evento, mudanças de preços são assumidas por serem observáveis, verificáveis e relevantes.

$\mathrm{Na}$ definição apontada por Hendriksen não existe uma definição distinta de transações, eventos ou fenômenos; demonstra que nem todas as características dos eventos podem ser mensuradas e reportadas em termos monetários.

Nos eventos relacionados com o processo de negociação de jogadores, constatou-se que cada evento possui características quantitativas e qualitativas. Neste estudo, em específico, assumese que estas características serão tratadas como variáveis ou parâmetros.

Tem-se em vista que cada evento possui um conjunto de variáveis quantitativas e qualitativas, e somente algumas podem ser mensuradas. Deste modo, o objetivo é reunir as características passíveis de mensuração, de forma que o gestor possa medir o impacto econômico de cada evento ligado ao processo de negociação de jogadores.

Parisi (In: CATELLI, 2001) argumenta que um dos primeiros passos para avaliação e mensuração de um evento é identificar o momento da ocorrência de uma transação.

Em consonância às definições anteriores, pode-se verificar que a gestão econômica de jogadores de futebol primeiramente deve identificar as principais transações que se pretende realizar e, daí em diante, iniciar o processo de mensuração deste ativo.

Parisi e Nobre (In: CATELLI, 2001, p. 113) descrevem que o

[...] evento pode ser entendido como um conjunto de transações, cujos atributos lhe dão forma e consistência, ou seja, um conjunto de transações da mesma natureza ou classe que pode envolver uma ou mais entidades e estar relacionado com um produto, com um serviço, ou ainda com um lote de produtos e/ou com centro de responsabilidade que o causou. 
Na visão de Guerreiro (1989, p. 248), “[...] as atividades desenvolvidas pela empresa assumem o caráter de eventos econômicos", onde "Os eventos econômicos se constituem nos objetos de tomada de decisão, e os indivíduos que tomam decisão são os gestores. Os gestores são, portanto, os responsáveis pelo processo de tomada de decisões econômicas na sua esfera de atuação."

Tendo em vista que os eventos são frutos das decisões, Parisi (In: CATELLI, 2001) apresenta as seguintes características para os eventos:

- $\quad$ alteram a situação patrimonial da empresa;

- $\quad$ são previsíveis e, portanto, podem ser estruturados num sistema de informação;

- $\quad$ dizem respeito à performance da organização e acabam refletindo os modelos de decisão restritos dos gestores;

- $\quad$ seus efeitos são mensuráveis monetariamente.

Observa-se que os principais eventos de uma empresa estão relacionados com o objetivo fim das atividades empresariais.

Catelli (2001) afirma que o termo ‘econômico' refere-se a valores validados pelo mercado em determinado período, devendo ser considerado o valor do dinheiro no tempo.

Uma vez conceituado evento e suas características, busca-se então identificar os eventos econômicos e os elementos que alicerçam seus vínculos ao processo de gestão dos ativos “jogadores de futebol”, assim ilustrados na figura abaixo:

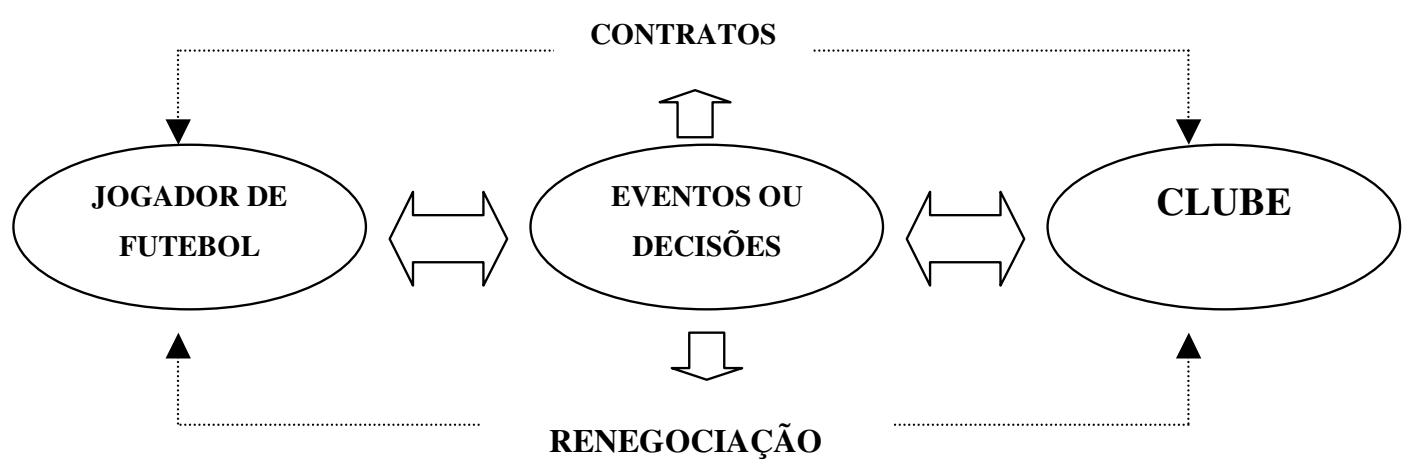

Figura 9 - Os eventos ou decisões entre clube - atletas 
No estudo de caso foram identificados sete eventos possíveis ao processo de negociação e gestão de atletas. Estes eventos são alicerçados por contratos, com tempo médio de cinco anos que asseguram direitos e deveres entre as partes, tendo em vista os diversos eventos, devendose ressaltar que cada evento possui um conjunto de variáveis quantitativas e qualitativas.

Pode-se afirmar, ainda, que a identificação e mensuração dos eventos econômicos dependem do processo físico-organizacional da entidade.

Os eventos que serão detalhados a seguir baseiam-se nas possibilidades de transações com atletas identificadas no estudo de caso.

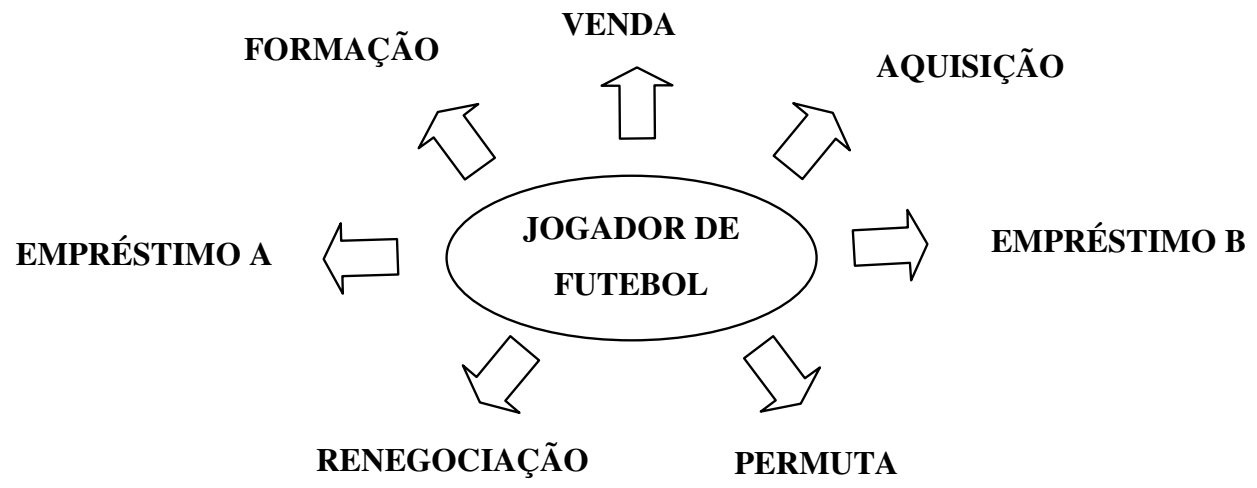

Figura 10 - Eventos - gestão de jogadores de futebol

Estas constatações foram obtidas nos depoimentos e subsidiaram a estruturação dos modelos de mensuração a partir das variáveis quantitativas. Entretanto, as variáveis qualitativas são imprescindíveis aos modelos de decisões, pois oferecem informações importantes e influenciam no processo de negociação dos ativos, informações como performance do atleta na última temporada, condições físicas, número de gols marcados, relacionamento com a "torcida", aspectos comportamentais e psicológicos etc.

Com base nos levantamentos e nas evidências diagnosticadas nas entrevistas com os gestores, apresenta-se a proposta de um modelo de identificação para os eventos diagnosticados. Entretanto, antes de explicar os objetivos do modelo de identificação, faz-se necessária uma abordagem sobre: o que é um modelo; qual a função de um modelo; qual sua importância no processo de tomada de decisão. 


\subsubsection{Conceito e definições}

De acordo com Miranda (1985, p. 19), “[...] modelo é uma representação simplificada da realidade. Apesar de simples [...] Ela abarca desde uma descrição verbal até os mais sofisticados modelos matemáticos."

Diante do conceito citado por Miranda, entende-se que os modelos têm como objetivo a abstração da realidade e são construídos sobre uma base conceitual que visa descrever a realidade e seus comportamentos.

Miranda (1985, p. 19), citando Cecília Kobata, apresenta outra definição de modelo: “[...] modelo é uma representação não idealizada de uma realidade que inclui estados, eventos e objetos, levando em conta apenas os aspectos relevantes da mesma, simplificando-a."

Esta definição vem ao encontro dos objetivos a que se propõe a estruturação do modelo de identificação para apontar as variáveis e os parâmetros relevantes à decisão ou eventos ligados ao processo de negociação dos ativos humanos do futebol.

A construção de modelos de decisão a partir das informações disponíveis, segundo Hendriksen e Van Breda (1999), é importante, pois possibilita uma maior regularidade em termos de qualidade das decisões.

Miranda (1985, p. 3) aborda que os modelos para as ciências sociais - entre as quais se inclui a contabilidade - são necessariamente uma aproximação da realidade, porque é impossível captá-la integralmente e porque esta é mutável com o passar do tempo.

Face os conceitos apresentados e as evidências (os achados) do estudo de caso "Clube Atlético Paranaense", apresenta-se um modelo de identificação que objetiva identificar e classificar os eventos e as variáveis inerentes ao processo de gestão de jogadores de futebol.

Parisi (In: CATELLI, 2001) define que a questão crucial do modelo de identificação reside em identificar as transações, ou seja, para uma transação se manifestar, pelo menos um gestor precisa tomar uma decisão que envolva recursos econômicos da entidade em determinado instante de tempo e, então, ele deve ser responsável por esse ato e ter condições de responder sobre esse feito. 


\subsection{Modelo de identificação}

A estruturação do modelo de identificação leva em consideração algumas funções como reconhecimento da transação; reconhecimento das variáveis quantitativas e qualitativas; classificação da transação; e registro da transação. Com base nas evidências apontadas pelo estudo, apresenta-se, a seguir, uma proposta de Modelo de Identificação.

Quadro 2 - Modelo de identificação

\begin{tabular}{|c|c|c|}
\hline \multicolumn{3}{|c|}{ MODELO DE IDENTIFICAÇÃO } \\
\hline \multicolumn{3}{|l|}{ EVENTO: Contratação de jogadores } \\
\hline VARIÁVEIS & QUANTITATIVAS & QUALITATIVAS \\
\hline PROVÁVEIS RECEITAS (Recebimentos) & & \\
\hline Ingressos em Jogos & & \\
\hline Produtos Licenciados & & \\
\hline Exploração dos Direitos de Imagem & & \\
\hline Outras Receitas & & \\
\hline $\begin{array}{lrllll}\begin{array}{l}\text { CUSTOS E } \\
\text { desembolsos) }\end{array} & \text { DESPESAS } & \text { OPERACIONAIS } & \text { (pagamentos } & \mathrm{e} \\
\end{array}$ & & \\
\hline $\begin{array}{l}\text { Desembolso Inicial (Direito Federativo/ Passe / Taxa de } \\
\text { Transferência) }\end{array}$ & & \\
\hline Salários & & \\
\hline Prêmios por Campeonatos & & \\
\hline Prêmios por Jogo (bicho ou luvas) & & \\
\hline Custos Operacionais & & \\
\hline Despesas e Custos (contratos) & & \\
\hline$\%$ de Direito de Imagem & & \\
\hline$\%$ de Direito de Arena & & \\
\hline Seguro por Temporada & & \\
\hline Outros Custos e Despesas & & \\
\hline ASPECTOS HISTÓRICOS E ESPORTIVOS & & \\
\hline Idade & & \\
\hline $\mathrm{N}^{\circ}$ de Clubes em que Atuou & & \\
\hline $\mathrm{N}^{\mathrm{o}}$ de Títulos Conquistados & & \\
\hline $\mathrm{N}^{\circ}$ de Gols Marcados & & \\
\hline Posição em que Atua & & \\
\hline Relacionamento com a Torcida & & $\begin{array}{l}\text { () Bom () Regular () } \\
\text { Insatisfatório }\end{array}$ \\
\hline Desempenho Atual (performance) & & $\begin{array}{l}\text { () Bom () Regular () } \\
\text { Insatisfatório }\end{array}$ \\
\hline Outras Variáveis & & \\
\hline
\end{tabular}

O modelo de identificação proposto tem como objetivo identificar os eventos relacionados às transações com jogadores e, de maneira específica, reconhecer as variáveis relevantes aos 
respectivos eventos, sendo que o objetivo maior deste modelo é oferecer subsídios à estruturação dos modelos de mensuração e decisão.

Identificados os eventos e suas respectivas variáveis (Quadro 2), parte-se, então, para a estruturação do modelo de mensuração com base nas variáveis apontadas pelo estudo de caso.

\subsection{Modelo de mensuração}

\subsubsection{Conceitos e definições}

Antes de conceituar modelos de mensuração deve-se reportar aos aspectos citados no capítulo 3 , no qual conceitos, critérios e atributos do processo de mensuração foram discutidos.

Tendo em vista os conceitos e o conjunto de características dos sistemas de mensuração, Mock e Grove, citados por Guerreiro (1989), definem sistema de mensuração como o conjunto de procedimentos que atribui números a objetos e eventos, com o objetivo de promover informações válidas, confiáveis, apropriadas e econômicas para os tomadores de decisões.

Deste modo, espera-se que as medidas sejam válidas e representem os verdadeiros atributos das organizações ou entidades de interesse. Assim, busca-se subsídio e justificativa para a estruturação de um modelo que atenda as características do caso estudado.

Homburger, citado por Guerreiro (1989, p. 82), menciona que "[...] a quantidade de custo de um ativo em qualquer negócio particular depende não só do tempo e lugar, mas de julgamentos, esperanças, medos e preferências, tanto do comprador quanto do vendedor." Observa que o julgamento de quem mede é uma das características que diferenciam o valor do objeto que se pretende medir.

Chambers, citado por Guerreiro (1989, p. 88), afirma que a “[...] mensuração é atribuição de números a objetos eventos de acordo com regras, especificando o objeto a ser medido, a escala e as dimensões da unidade", e acrescenta o aspecto temporal da decisão. 
Segundo Guerreiro, a mensuração de objetos não se restringe a uma base de tempo. Tomadores de decisão necessitam de informações relativas a eventos e objetos do passado, presente ou futuro. Diferentes tipos de informações requerem informações as quais devem ser mensuradas em bases apropriadas. Cita o exemplo da venda de um imóvel comprado anteriormente: a decisão de vender requer a mensuração de seu valor presente, a fim de determinar a decisão do preço. Salvo na existência de motivos urgentes, o imóvel não deveria ser vendido com prejuízo.

O tipo de decisão que será tomado influenciará a correta mensuração do objeto ou evento. Nesta mesma linha, estão as diversas decisões possíveis para a gestão de jogadores, onde mensurar significa traduzir o valor econômico dos objetos ou eventos em um único padrão de medida que, no caso da contabilidade, é o padrão monetário, meio útil de se atribuir um significado comum a objetos ou eventos diferentes.

Guerreiro (1989, p. 90) afirma

[...] que a contabilidade, obedecendo ao princípio do denominador comum monetário, tem utilizado somente a escala monetária para mensurar os objetos e eventos. Entendemos, contudo, que principalmente para finalidades gerenciais, os sistemas de informações contábeis deveriam fornecer informações mensuradas tanto pela unidade monetária, como por escalas físicas.

Diante do exposto, o processo de avaliação de jogadores de futebol contempla aspectos como salários, prêmios, seguros, bichos pagos, exploração do direito de imagem, direito de arena, custos operacionais, ou seja, variáveis que podem ser medidas, mensuradas em unidades monetárias.

Contudo, as variáveis qualitativas não são mensuradas monetariamente, mas devem ser identificadas, pois podem influenciar a decisão.

\subsubsection{Metodologias de avaliação}

O processo de avaliação requer o estudo conjunto do complexo das variáveis que influenciam a decisão, pois o mercado de negociação de jogadores é dinâmico e sensível à especulação. 
Deste modo, pode-se citar o exemplo da influência ${ }^{40}$ dos empresários que realizam trabalhos como: cds, fitas de vídeo, preparam currículos, fotos, estatísticas dos atletas, passagens por seleções, enfim tudo aquilo que possa influenciar ou agregar valor à transação.

Descrito o processo, discute-se que o modelo de mensuração proposto se encontra fundamentado em uma metodologia que permite mensurar os ativos de forma objetiva e confiável, sendo que o tratamento contábil deve refletir o valor econômico do jogador de futebol, permitindo, deste modo, relacionar as variáveis presentes com o modelo de decisão e o valor econômico do ativo. Para isto, utilizou-se o conceito de valor presente de fluxos de caixa futuros, uma metodologia utilizada para avaliação econômica de ativos.

A metodologia de fluxo de caixa descontado, conforme Alencar (1998, p. 79), considera que a característica principal de um ativo é a sua capacidade de prestar ou gerar serviços futuros à entidade que tem sua propriedade, ou seja, domínio. Desta forma, é praticamente unânime que a forma de mensuração que mais se aproxima conceitualmente da natureza dos ativos seria sua mensuração a valor presente de seus fluxos de serviços futuros.

Portanto, fica patente que os clubes não desejam um jogador por ele próprio, mas sim pelas características do indivíduo, movidos por desejos não necessariamente racionais, para atender atividades operacionais, desejos e status da equipe, satisfação da torcida - fãs, interesse pessoal, segurança da equipe nos campeonatos etc.

Os clubes desejam os serviços "habilidade implícita" que são proporcionados por um determinado bem, e que são capazes de se transformar, direta ou indiretamente, em fluxos líquidos de caixa.

O jogador de futebol, para o clube, não foge à regra, ele representa um fluxo futuro de benefícios para a entidade que explora este ativo humano, e é imprescindível para assegurar a continuidade e crescimento econômico do clube. Desta forma, a avaliação destes ativos é fundamental à sua gestão, somente assim o gestor pode avaliar o impacto econômico de cada evento sobre o patrimônio do clube.

\footnotetext{
${ }^{40}$ Ver matéria escrita por Cláudio, colunista esportivo do site: <www.futebolmundo.com.br>.
} 
Diante da necessidade de encontrar metodologias que auxiliem a avaliação destes eventos e seus impactos econômicos no resultado do clube, discutem-se algumas metodologias de avaliação de ativos, a fim de apontar uma metodologia que aproxime as características deste ativo ao seu valor econômico.

Stermole e Stermole (1990, p. 372-375) fazem uma abordagem sobre três métodos de avaliação utilizados por bancos de investimentos e investidores, usados para determinar ou estimar o valor de mercado de um investimento: o custo de reposição, o valor de mercado baseado em transações semelhantes e o resultado do desconto a valor presente dos fluxos futuros de entradas e saídas de caixa (VPL).

O método de custo de reposição consiste em avaliar o custo (preço) para a terra, os direitos minerais, edifícios e equipamentos, estradas, infra-estrutura, e outros custos para se repor uma infra-estrutura, operação de produção, instalação e investimento em geral, de forma a se obter uma unidade exatamente igual à atualmente existente.

A aplicação deste método de avaliação poderia ser feita para jogadores de futebol formados pelas categorias de base dos clubes que, segundo Michie e Verma (1999, p.7), consistiria em contabilizar tais jogadores ao valor de reposição, ou seja, equivale a contabilizar a quantia necessária para a substituição daquele jogador no mercado livre. Identificar o custo de reposição do jogador também envolve uma avaliação subjetiva, uma vez que o custo de reposição atual só pode ser determinado objetivamente quando o jogador é substituído de fato.

Alencar (1998, p. 82) afirma que "[...] a dificuldade está em se indicar todos os custos que realmente são relevantes. Projetos que, em um primeiro momento, parecem semelhantes ou exatamente iguais, podem ter custos de desenvolvimento e/ou operação completamente diferentes." Esta metodologia não avalia o potencial de serviços futuros dos ativos, mas sim os ativos que lá se encontram.

Outra metodologia refere-se ao método das vendas comparadas que consiste em se obter, no mercado, os preços praticados em transações recentes com propriedades ou investimentos similares àqueles que estão sendo avaliados. 
De acordo com Stermole e Stermole (1990), este método funciona muito bem para imóveis residências, quando existe uma quantidade significativa de negócios com propriedade similares, em localização equivalente e em um período relativamente curto de tempo.

O uso do método das vendas comparadas na avaliação de jogadores de futebol seria um processo ainda mais complexo, pois se utilizaria de uma metodologia que considera como parâmetro as vendas ou contratações de atletas semelhantes que jogam na mesma posição, têm a mesma idade, atuam em clubes semelhantes. Acredita-se que esta metodologia não reflita o valor econômico do ativo que está sendo avaliado, pois o número de variáveis envolvidas no processo de avaliação aumenta significativamente devido à volatilidade do preço (do passe, direito federativo) acompanhar o desempenho, ou seja, a performance do atleta e o momento em que ele é negociado (início, meio, ou final de temporada ou campeonato).

Devido à particularidade destes ativos, cujos serviços dos atletas equiparam a um direito, Hendriksen e Van Breda (1999) afirmam que os ativos intangíveis são ativos sem substância, estes ativos formam uma das áreas mais complexas da teoria da contabilidade, em parte em virtude das dificuldades de definição, mas principalmente por causa das incertezas a respeito da mensuração de seus valores e da estimação de suas vidas úteis.

A avaliação de investimentos, seja na formação seja na aquisição de jogadores, encontra-se sob condições que modificam o valor destes ativos. Condições como: o clube onde o jogador atua, os campeonatos participantes, os salários pagos, gastos com formação, o seguro pago, o programa de assistência ao atleta, a estrutura do clube, o tamanho da torcida, estes fatores observados são fundamentais na determinação do preço pelo qual o investimento é ou foi transacionado.

Quanto ao Método de Resultado de Desconto a Valor Presente do Fluxo Futuro de Entradas e Saídas de Caixa (VPL), Aversari Martins (2002, p.45) aponta as principais características que interessam ao assunto e as resume em:

- determinado pelo processo do desconto a valor presente dos fluxos de caixa futuros por taxas de juros que expressem os riscos associados a esses fluxos de caixa;

- para alguns ativos que geram benefícios de forma indireta a aplicabilidade fica prejudicada;

- forma de avaliação que aproxima a forma de avaliação à definição conceitual de ativo;

- busca o valor econômico da entidade, e é influenciado por custos de oportunidade; 
- utilizando para avaliação econômica dos ativos líquidos de uma entidade.

Ainda segundo Aversari Martins (2002), a utilização do valor presente líquido pode causar alguns problemas de ordem prática, além de ter sido provavelmente o causador da maioria dos problemas relacionados à confusão entre definição de ativos e sua mensuração.

Mesmo diante das limitações do valor presente de caixa futuro, neste estudo se propõe a sua utilização como uma alternativa à avaliação dos eventos diagnosticados no estudo de caso, de modo que o gestor possa ter um parâmetro para a avaliação do jogador.

\subsubsection{Custo de oportunidade como medida de avaliação}

$\mathrm{Na}$ vida tanto dos homens quanto das entidades, são feitas escolhas e renúncias, "compro um carro à vista ou a prazo", "vou ao cinema ou ao teatro", cada escolha representa um evento econômico e sua avaliação consiste no processo de medir, avaliar o desempenho de cada decisão, tanto no plano financeiro quanto econômico e operacional, e para isto o conceito de custo de oportunidade representa um parâmetro, uma medida sustentada em função da escolha feita.

De acordo com Pereira (1990, p. 8), o conceito de custo de oportunidade, tanto em economia como em Contabilidade e Finanças, tem fundamento na questão da escolha entre alternativas de utilização de recursos. Todavia ele - custo de oportunidade - só aparece claramente após as alternativas terem sido elencadas e mensuradas.

Já Horngren (1978, p. 528) entende que o "[...] custo de oportunidade é o sacrifício mensurável da rejeição de uma alternativa, e o lucro máximo que poderia ter sido obtido se o bem, serviço ou capacidade produtiva tivessem sido aplicados em outro uso opcional.”

Guerreiro (1989, p. 7) afirma que "[...] em termos práticos, o custo de oportunidade corresponde à remuneração mínima exigida pelos acionistas sobre seu investimento na empresa."

Alencar (1998, p. 116) observa que, dentre os conceitos dos diversos, eles se encaminham na direção de que o custo de oportunidade deve representar o custo da escolha de determinada 
alternativa em detrimento de uma outra que proporcionasse um outro benefício quantificável, ou seja, é o custo da melhor oportunidade a que se renuncia quando da tomada de decisão de outra oportunidade.

Guerreiro (1995, p. 60) discute que

[...] o patrimônio de uma entidade em determinado momento representa o quanto vale essa empresa, considerando os valores de mercado baseados no custo de oportunidade para mensuração dos potenciais de serviços dos ativos que possui, e considerando o valor do dinheiro no tempo, onde o lucro de um período corresponde ao incremento no estoque da companhia nesse período.

Deste modo, os conceitos apresentados expressam como o conceito de custo de oportunidade é uma alternativa para medir e verificar se os esforços financeiros e econômicos se justificam. De modo semelhante, pretende-se verificar os investimentos realizados: na formação, na aquisição, na determinação do momento de venda, ou até mesmo se o empréstimo ou a permuta de um determinado atleta representarão uma alternativa viável.

Todas as decisões anteriormente citadas poderiam basear-se ou fundamentar-se neste conceito como um dos parâmetros para avaliar se as decisões que serão ou que foram tomadas, de fato, proporcionam a melhor escolha para o clube.

O modelo de mensuração proposto tem como objetivo oferecer ao gestor não só informações de caráter preditivo, mas possibilitar a ele também avaliar o impacto das decisões passadas, presentes e futuras. Este instrumento proposto tem a finalidade de oferecer-lhes a possibilidade de avaliar as decisões ou eventos relacionados à gestão dos ativos (jogador), o que pode melhor ser visualizado na figura 11 a seguir. 


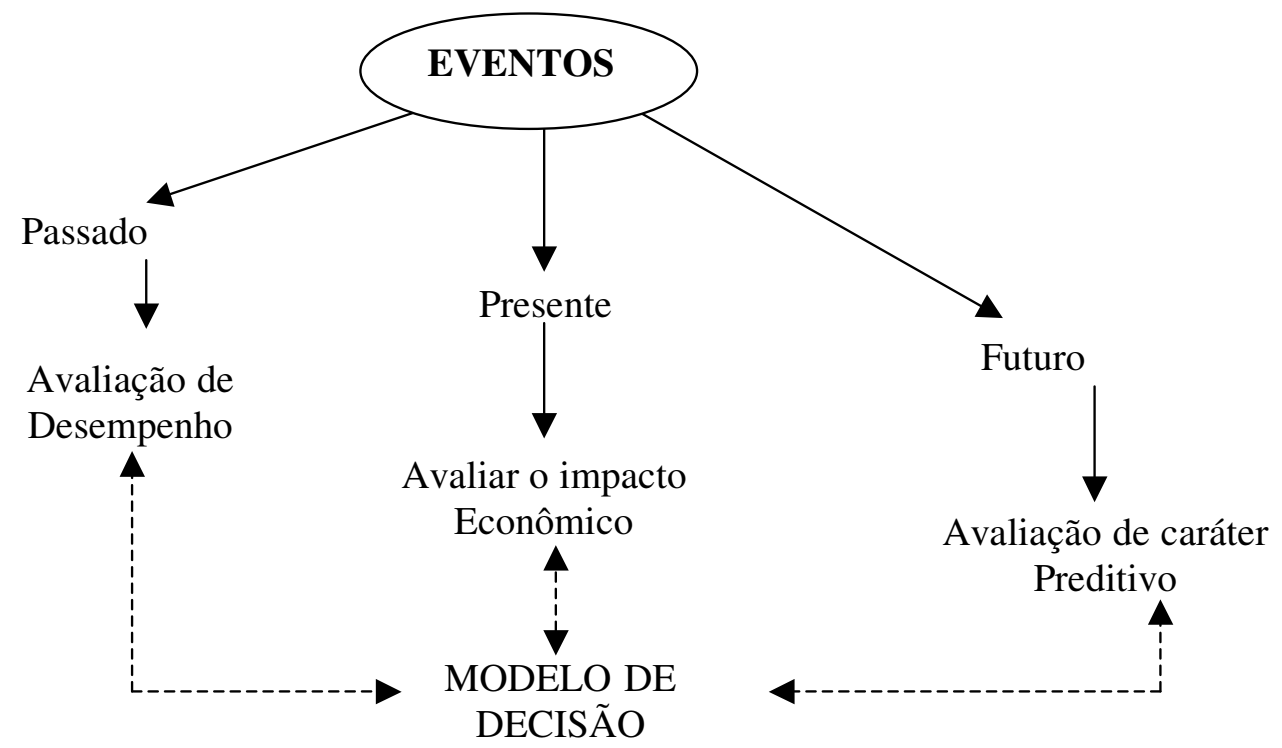

Figura 11 - Os eventos e sua relação temporal

A metodologia de valor presente foi utilizada para apurar o valor econômico dos fluxos de benefícios futuros e, para avaliar o impacto das decisões, juntamente, fundamentou-se nos custos de oportunidades como alternativa para avaliação da alternativa escolhida ou que se pretende escolher.

A metodologia proposta caracteriza-se como um modelo matemático utilizado para mensuração dos eventos do estudo que procura representar de modo simplificado o impacto da decisão no resultado do clube.

Barbante, citado por Miranda (1985, p. 20), aborda que Modelo Matemático é “[...] uma imagem idealizada do mundo real, em que as inter-relações entre as diferentes variáveis econômicas se representam com a ajuda do simbolismo matemático e o processo ordinário de dedução é substituído por operações matemáticas." 


\subsubsection{Fundamentos do modelo de mensuração}

Tem-se em vista que o processo de agregação de valor da empresa é fruto das decisões que os gestores tomam e que provocam processos de troca física de recursos ao longo de toda a cadeia.

Lustosa (2001) comenta que cada estágio das atividades operacionais de uma entidade envolve trocas ou transações. Tendo de um lado o consumo de recursos e do outro os produtos gerados, como ambos, recursos e produtos, têm valor econômico, haverá impacto econômico sempre que os seus valores forem diferentes. Por isso, uma transação pode ser definida como qualquer ocorrência que produz impacto no patrimônio da empresa.

Pereira (2000) define que o conjunto de transações de uma mesma categoria ou classe caracteriza um evento econômico. Sendo assim, os eventos podem ser de compra (aquisição de recursos), produção (transformação de recursos), venda de produtos e serviços e tempo conjuntural. Os eventos citados ocorrem em função das decisões dos gestores que, portanto, exercem controle sobre eles.

A empresa, para Lustosa (2001, p. 100), “[...] é um agregado de decisões econômicas, sendo as atividades operacionais o meio através do qual as decisões são planejadas, implementadas e controladas."

\subsubsection{O valor econômico - ativo}

Para Lustosa (2001, p. 101), o valor econômico pode ser entendido como "[...] todo evento que envolve o recebimento (benefício) de um recurso em troca da entrega (sacrifício). Diz que houve ganho na decisão sobre um evento quando o valor econômico dos recursos obtidos for superior ao dos recursos sacrificados. Na perda ocorre o contrário."

Na visão de Kenneth MacNeal (1970, p. 87),

[...] o valor econômico é uma medida da importância relativa que uma comunidade, exibindo suas preferências coletivas através do processo de mercados, atribui a um bem específico em comparação com outros bens. Em outras palavras, o valor econômico de qualquer recurso é só seu 'poder de troca', que em termos monetários é o seu preço de mercado. 
Segundo Catelli (2001), os ativos e passivos são avaliados pelo valor econômico desses recursos, tais elementos patrimoniais se originam, como visto, de decisões tomadas pelos gestores sobre os eventos econômicos.

É preciso ressaltar a distinção entre os conceitos de valor econômico e preço de mercado de um ativo, uma vez que o autor anteriormente citado não separa claramente os conceitos.

O valor econômico tem sua origem definida pelos grandes economistas teóricos, como o conceito de capital e renda. Fisher apud Silva (2000, p. 127) afirma: "Estritamente falando, então, ao construir nossas estatísticas de renda, devemos sempre calcular o valor dos serviços, e nunca o valor dos objetos prestados desses serviços."

Lustosa (2001, p. 102), ao comentar a definição de Fisher, aborda que a renda representa a valoração monetária, a preços de mercado, dos fluxos físicos que emanam (fluem) de um objeto (capital), não devendo com este ser confundido. Por outro lado, a renda, ao mesmo tempo em que deriva do capital, determina, após dedução dos custos necessários para extração dos respectivos serviços, o valor do próprio capital.

Ainda de acordo com Fisher apud Silva (2000, p. 130):

[...] o valor do capital deve ser computado do valor de sua renda líquida futura estimada e viceversa. Essa colocação pode, de início, parecer confusa, porque usualmente pensamos nas causas e efeitos como funcionando para frente e não para trás no tempo. Poderia parecer, então, que a renda é derivada de bens de capital. Mas o valor da renda não é derivada do valor dos bens de capital. Pelo contrário, o valor do capital é derivado do valor da renda. Os eventos vindouros lançam, antes, suas sombras. Nossas avaliações são sempre antecipações.

Deste modo, entende que o valor de um ativo representa em termos econômicos, para a entidade que detém a sua posse e controle, as rendas líquidas esperadas futuras derivadas dos seus serviços valorados a preços de mercado. Nesta mesma linha, Martins (1972, p. 30) defende que um ativo é o futuro resultado econômico que se espera obter de um agente.

Lustosa (2001, p. 103) comenta que

A compreensão econômica de ativo, que o valor econômico é uma medida que não existe separadamente da entidade que detém a posse desse ativo, usufruindo dos seus serviços. Em outras palavras, no sentido econômico, um mesmo ativo pode ter diferentes valores conforme sejam suas rendas líquidas esperadas pela entidade que o utiliza. 
Neste mesmo sentido, Catelli (2001) afirma que o patrimônio líquido a cada momento deve expressar o valor econômico da entidade, na perspectiva dos gestores que a dirigem.

\subsubsection{O valor de mercado - ativo}

Ao contrário do valor econômico do ativo, em que a avaliação é focada no volume físico de serviços esperados do agente ao longo de um tempo futuro, o valor de mercado foca o próprio agente, podendo ser este um insumo, produto ou serviço. Lustosa (2001) faz uma pequena adaptação no conceito que MacNeal (1970, p. 87) formulou para valor de econômico, e define valor de mercado como:

\footnotetext{
Uma medida da importância relativa que uma comunidade, exibindo suas preferências coletivas através do processo de mercado, atribui a um bem específico em comparação com outros. Em outras palavras, o valor de mercado de qualquer recurso é só seu 'poder de troca', que em termos monetários é o seu preço de mercado.
}

O valor de mercado de um ativo é reflexo do processo de oferta e procura, sujeito a flutuações de um bem negociado, onde os preços refletem o grau de importância que o mercado atribui a ele naquele momento. Além disso, o valor de mercado considera diversos atributos para a formação do preço (qualidade dos produtos, processos operacionais, impactos das condições macroeconômicas e concorrência etc.).

Logo, o valor de mercado é diferente do valor econômico, pois o valor de mercado, segundo Lustosa (2001), é aquele validado pelo preço de mercado, é avaliado em função dos participantes do mercado, vinculados a um processo dinâmico que envolve diferentes percepções de utilidade, preferência a risco e até especulação.

Para Lustosa (2001, p. 105), “O valor econômico líquido de um ativo, individualmente ou agregado por atividade, departamento, empresa, representa o custo de oportunidade do recurso, ou seja, quando o dono do capital deixará de ganhar ao decidir descontinuar o ativo.”

\subsubsection{A lógica do modelo de mensuração}

No processo de obtenção de recursos, o gestor sempre terá de renunciar a outras alternativas que atenderiam a sua necessidade em prol da decisão efetivamente tomada, uma vez que os recursos podem ser obtidos sob condições diferentes da escolha, onde obter um determinado 
recurso por custo $\mathrm{X} 1$ implica na renúncia à obtenção desse mesmo recurso por custo $\mathrm{X} 2$ diferente.

A mensuração dos eventos vinculados à negociação de jogadores pode ser entendida na definição de custo de oportunidade de Ronald Coase apud Zimmermam (1995, p. 23) “[...] os recebimentos que poderiam ter sido obtidos se aquela decisão particular não tivesse sido tomada."

Lustosa (2001) afirma que o custo de oportunidade não tem sido muito utilizado pela contabilidade, sendo que as supostas razões devem-se ao fato de estar implícito no conceito que as decisões envolvem um resultado econômico, quando se compara o sacrifício com os "recebimentos que poderiam ser obtidos" em uma decisão alternativa. No entanto, a contabilidade tem o costume de focar o resultado de cada decisão somente no 'custo'.

O modelo de mensuração proposto para avaliação de jogadores de futebol apóia-se sobre o conceito de custo de oportunidade, como definido por Coase. Além dos conceitos abordados, três aspectos são imprescindíveis para aplicação, como exposto a seguir.

- A escolha prévia do evento - significa que o objetivo (o quê fazer), enquanto necessidade operacional de uma determinada etapa da cadeia produtiva já está decidido. Falta escolher apenas como fazer, qual alternativa selecionar para cumprir esse objetivo. Assim, não existe um conjunto indefinido de oportunidades para a obtenção ou uso alternativo do recurso. A oportunidade limita-se ao objeto da decisão (evento) selecionado. Não cabem comparações que envolvam renúncia ao objetivo pretendido, do tipo "se não tivesse que obter esse produto, o que poderia ser feito?" A necessidade do produto já está definida, por exemplo, comprar o atleta $\mathrm{X}$ ou pegar emprestado, vender ou emprestar, contratar ou permutar, renegociar ou contratar um atleta mais jovem, são alternativas disponíveis para viabilizar o objetivo já decidido.

- As condições de equivalência para a segunda melhor alternativa desprezada - definido o objetivo (produto), este deverá reunir os atributos que lhe permitirão atender às necessidades de quem dele fará uso. Todos os atributos quantitativos e qualitativos como: salários, multa rescisória, prêmios, bichos, custo operacional, posição em que atua, requisitos de performance, tempo de contrato, quantidade, risco etc. 
Estes atributos considerados na alternativa aceita não estão presentes na segunda melhor alternativa renunciada, tendo em vista a particularidade de cada decisão (comprar, emprestar, permutar, vender e formar), e o alto grau de subjetividade (incerteza) em determinar os benefícios futuros de cada decisão. Por exemplo, entre contratar o jogador Ronaldinho, do Clube Real Madri, e comprar os serviços de um jogador que satisfaça a alternativa escolhida.

Diante deste contexto, estruturou-se uma proposta, em que o modelo de apuração leva em consideração a seguinte premissa, “o custo de oportunidade financeiro da aplicação dos sacrifícios da alternativa escolhida é uma alternativa válida para apuração do resultado de cada decisão ou evento vinculado à gestão de jogadores de futebol”.

- Custo de oportunidade baseado nos preços de mercado - esta característica transforma a idéia de "custo", contida na oportunidade desprezada, em uma medida de valor econômico, operacionalizando, em termos práticos, o modelo de mensuração, uma vez que o custo da alternativa desprezada é que nos dá a medida do valor da alternativa aceita. E assim, conhecer o custo dos serviços de um ativo, precificados a valor de mercado e ajustados pelo valor do dinheiro no tempo 'VPL' custo financeiro de oportunidade, é o valor econômico dos seus benefícios.

De forma resumida, o modelo de mensuração foi estruturado sobre esta lógica, tem-se então: escolha prévia dos eventos (formar, comprar, vender, emprestar, permutar e renegociar) e identificação das variáveis relevantes e mensuráveis monetariamente de cada evento. A receita de oportunidade é o valor futuro da aplicação do VPL (recebimentos - pagamentos), ou seja, a segunda melhor alternativa desprezada sob condições equivalentes com a alternativa aceita - a remuneração que o gestor teria se tivesse aplicação financeira; custo de oportunidade (recebimentos desprezados) baseado nos preços de mercado.

Portanto, o modelo de decisão proposto leva em consideração os recebimentos desprezados na segunda melhor alternativa (valor econômico do recurso), quando comparado com sacrifícios incorridos na alternativa aceita, que podem caracterizar uma receita de oportunidade ou despesa de oportunidade. Conforme a natureza da transação (desembolso ou conta a pagar) é 
confrontada com a receita de oportunidade (valor econômico do recurso adquirido); na venda de um produto, o benefício (entrada de caixa ou conta a receber) é comparado com os recebimentos que poderiam ter sido obtidos se o produto tivesse sido vendido pelo seu valor econômico (despesa de oportunidade).

\subsubsection{Detalhamento do modelo de mensuração}

O modelo de mensuração leva em consideração a maximização dos resultados econômicos pretendidos pelo clube, tem-se então que:

$$
\text { resultado }=\text { receita de oportunidade }- \text { vpl (fluxo de benefícios }- \text { fluxo e sacrifícios). }
$$

Onde o resultado obtido é a diferença entre a receita de oportunidade desprezada em função da alternativa escolhida menos o Valor Presente Líquido do Fluxo Benefícios Prováveis menos o Fluxo de Sacrifícios da Alternativa Escolhida, descontado por uma taxa de mercado.

Sendo que o modelo matemático que subsidia o modelo de apuração baseia-se em duas fases:

$1^{a}$. FASE - Busca através dos conceitos de valor presente, subsidiados na técnica de VPL valor presente líquido do fluxo de pagamentos e recebimentos, pela Equação: $V P L=\sum_{i-1}^{n} \frac{\text { Valores }_{i}}{(1+i)^{n}}$, e assim apura o valor presente líquido do investimento (evento ou decisão).

$2^{\text {a }}$ FASE - Tem como objetivo medir o resultado da segunda melhor alternativa desprezada, pela aplicação da Equação: $V F=\left(V P L \Leftrightarrow \sum_{i=1}^{n} \frac{\text { Valores }_{i}}{(1+i)^{n}}\right)$ e assim apura a receita de oportunidade do evento que se avalia. 


\subsubsection{O modelo de mensuração}

De acordo com os conceitos abordados, as evidências, os padrões simbólicos e as práticas empregadas no universo estudado, estruturou-se o seguinte Modelo de Mensuração genérico:

Quadro 3 - Modelo de mensuração

\begin{tabular}{|c|c|c|c|c|c|}
\hline \multicolumn{6}{|c|}{ MODELO DE MENSURAÇÃO } \\
\hline \multirow{3}{*}{ CONTAS } & \multicolumn{5}{|c|}{ EVENTO: CONTRATAÇÃO } \\
\hline & \multicolumn{5}{|c|}{ PERÍODO: MÊS / ANO } \\
\hline & $\begin{array}{l}\text { PERÍODO - } \\
01 \\
\end{array}$ & $\begin{array}{l}\text { PERÍODO - } \\
02 \\
\end{array}$ & $\begin{array}{l}\text { PERÍODO - } \\
03 \\
\end{array}$ & $\begin{array}{l}\text { PERÍODO - } \\
04\end{array}$ & $\begin{array}{l}\text { PERÍODO - } \\
05\end{array}$ \\
\hline $\begin{array}{l}\text { (+) RECEITA DE } \\
\text { OPORTUNIDADE }\end{array}$ & & & & & \\
\hline $\begin{array}{l}\text { (+) VPL - FLUXO DE BENEFÍC } \\
\text { (RECEBIMENTOS) }\end{array}$ & & & & & \\
\hline Receitas de Direito de Imagem & & & & & \\
\hline Receitas de Licenciamentos & & & & & \\
\hline Outras Receitas & & & & & \\
\hline 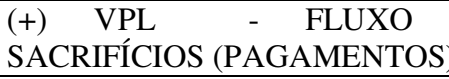 & & & & & \\
\hline Multa Rescisória & & & & & \\
\hline Salários & & & & & \\
\hline Custos Operacionais - Mensal & & & & & \\
\hline Seguro & & & & & \\
\hline Prêmios - Bicho & & & & & \\
\hline Prêmios - Finalizações de Camp. & & & & & \\
\hline Outras despesas & & & & & \\
\hline $\begin{array}{l}\text { (+/-) VPL - VALOR PRESENTE } \\
\text { LÍQUIDO }\end{array}$ & & & & & \\
\hline (=) RESULTADO & & & & & \\
\hline
\end{tabular}

\section{$5.4 \quad$ Modelo de decisão}

Os modelos de decisão possibilitam aos gestores realizar simulações a cada evento ou decisão, com objetivo de contribuir ao processo de planejamento, avaliação e previsão do impacto econômico de cada evento. Porém, o modelo de decisão não substituirá a ação dos gestores nos respectivos processos de negociação de jogadores.

Pereira (2000, p. 79) menciona que:

O modelo de decisão refere-se ao processo de tomada de decisões sobre eventos econômicos, considerando as alternativas existentes. De forma restrita, o modelo de decisão contempla as etapas do processo decisório, que envolve, basicamente: identificação do problema; levantamento 
de alternativas visando solucioná-lo; avaliação das alternativas; escolha de uma alternativa com base em critérios preestabelecidos. De forma ampla, o modelo de decisão compreende também os conceitos de mensuração dessas alternativas (grifos nossos)

A abordagem de Pereira (2000) enfoca que os modelos de decisão objetivam a escolha de alternativas. Sendo assim, o gestor tem a possibilidade de mensurar os eventos econômicos e, diante do resultado econômico de cada evento, tem a possibilidade de tomar decisão fundamentada nas informações disponíveis.

Miranda (1985, p. 8) reporta que

[...] o administrador do futuro precisará ter à sua disposição, além de instrumentos que forneçam um rol das mais prováveis configurações do ambiente sob o qual estará atuando a empresa (previsões), instrumentos que calculem o impacto de tais previsões sobre o seu negócio, e também permitir a elaboração tanto de simulação sobre situações limites do ambiente (cenários favoráveis e desfavoráveis) como simulação sobre cursos alternativos para a empresa.

Este estudo busca, através dos modelos de decisão, oferecer um ferramental que de fato auxilie o processo decisório.

Segundo Pereira (2000, p.179), “[...] o modelo de decisão restrito deve contemplar as variáveis relevantes do problema de decisão, de forma estruturada e integrada aos modelos de mensuração e informação, permitindo a identificação de todos os impactos econômicos causados pelos eventos."

Com base nos modelos de identificação e mensuração propostos, e depois de caracterizados os modelos de decisão para cada evento, utiliza-se um exemplo hipotético para simular sua aplicação.

\subsection{A interação dos modelos}

Tendo em vista que a finalidade é oferecer ferramentas ao controle gerencial, observando-se que as decisões inerentes aos processos de negociação de jogadores apresentam características específicas, torna-se indispensável que modelos propostos apresentem interação e cumpram o objetivo que é oferecer os parâmetros relevantes ao processo de negociação. 


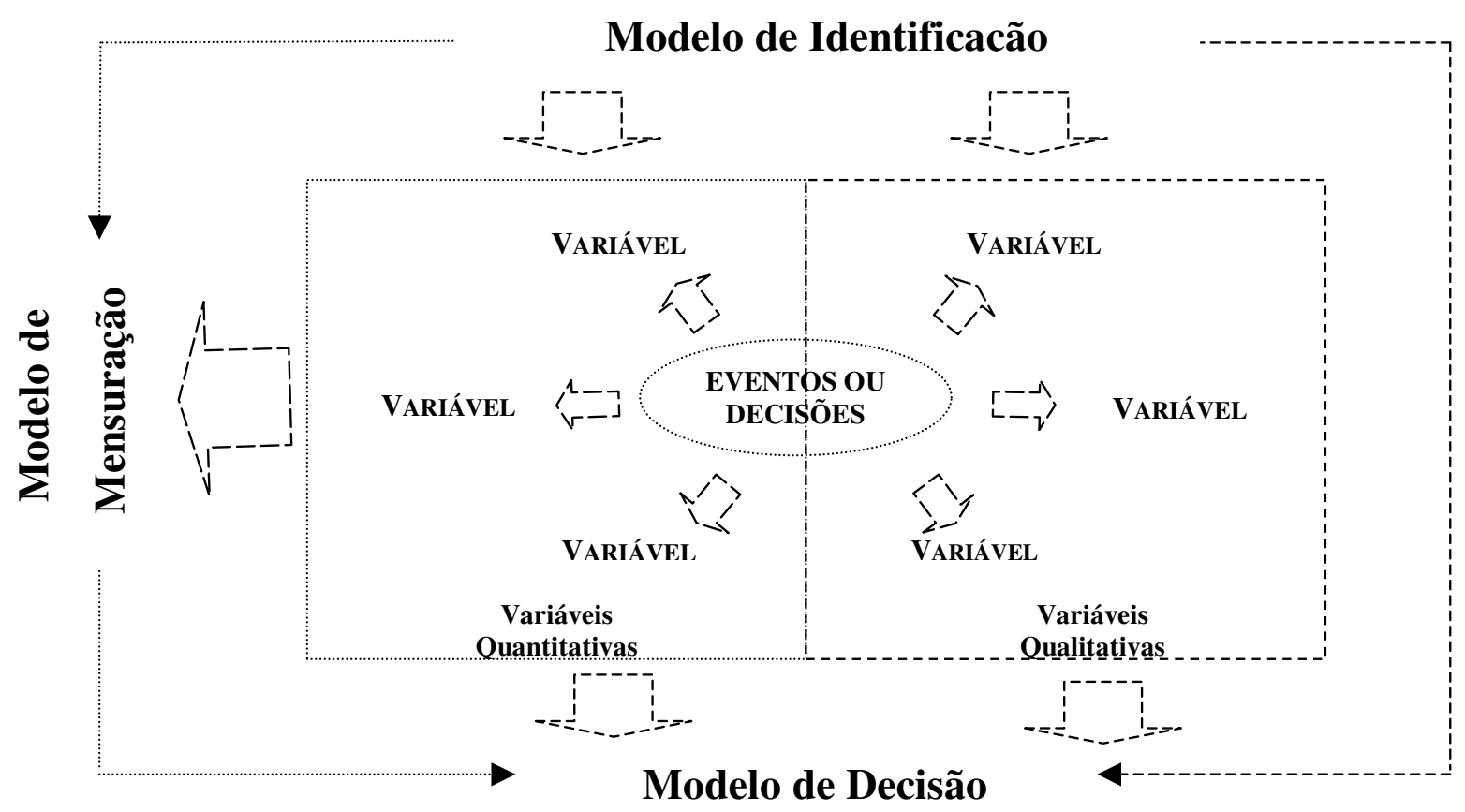

Figura 12 - A interação entre os modelos

O modelo de identificação tem como objetivo identificar: os eventos, as variáveis quantitativas e qualitativas, onde as variáveis quantitativas identificadas subsidiarão o modelo de mensuração, o qual tem como objetivo medir o impacto econômico de cada evento ou decisão.

Contudo, o modelo de decisão subsidia-se tanto das variáveis quantitativas quanto das qualitativas identificadas e o modelo de mensuração permite mensurar o impacto econômico das decisões causado pelas variáveis.

\subsubsection{Decisão de compra}

Este tipo de evento se caracteriza pela contratação ou aquisição: de direitos federativos, aquisição do passe, de um modo geral baseia-se na contratação dos serviços (habilidade) do jogador por um determinado período. Com o fim do passe os clubes firmam contratos com 
cláusulas de multas rescisórias que asseguram exclusividade sobre os serviços dos atletas por determinado período.

Os valores desembolsados pelos clubes na obtenção de jogadores representam valores expressivos. Devido à grandeza dos investimentos e por serem essenciais à continuidade das atividades da entidade, acredita-se que estes eventos devem ser mensurados e gerenciados.

\subsubsection{Características do evento}

O Clube Atlético de Futebol - USP pretende contratar um atleta com idade entre 20 a 23 anos. O clube tem uma política de fechar contratos com um tempo médio de 5 anos e as variáveis apontadas pelos gestores como relevantes ao processo de negociação, tendo em vista que o clube irá participar de campeonatos, são as descritas a seguir.

\subsubsection{Variáveis identificadas}

Condições Econômicas

Tempo de Contrato

Recebimento inicial

Desembolso Inicial (multa rescisória)

Custos Operacionais

Salários propostos

Seguro

Prêmio bicho

Prêmio Final de Campeonato

Direito de Imagem
Jogador A 5 Condição

anos

$\begin{array}{lrr}\mathrm{R} \$ 2.500 .000,00 & \text { moeda } \\ \mathrm{R} \$ & 850,00 & \text { mensal } \\ \mathrm{R} \$ & 60.000,00 & \text { mensal }\end{array}$

$\mathrm{R} \$ \quad 20.000,00 \quad$ anual

$\mathrm{R} \$ \quad 300,00 \quad \mathrm{p} /$ vitória

?

$?$

Não Ident.

Não Ident.

Condições Esportivas:

Campeonatos Estaduais 20

jogos

Campeonatos Regionais

jogos

Campeonatos Nacionais - Brasileiro

46

jogos

Outros jogos (amistosos)

10

jogos 
Condições Financeiras

Taxa de Desconto (custo oportunidade)

$2,50 \%$

ao mês

Taxa de Aplicação (custo oportunidade)

$1,50 \%$

ao mês

\subsubsection{Apuração do resultado do evento compra}

Diante do processamento das variáveis em consonância com os conceitos do modelo de mensuração, apurou-se o resultado do evento contratação que pode ser visto no quadro 4 .

Quadro 4 - Decisão de compra

\begin{tabular}{|c|c|c|c|c|c|}
\hline \multicolumn{6}{|c|}{ MODELO DE MENSURAÇÃO } \\
\hline & \multicolumn{2}{|c|}{ Período: 60 meses } & \multicolumn{3}{|c|}{ Evento: Compra - jogador A } \\
\hline CONTAS & Período 01 & Período 02 & Período 03 & Período 04 & Período 05 \\
\hline $\begin{array}{l}\text { (+) RECEITA DE } \\
\text { OPORTUNIDADE }\end{array}$ & $\begin{array}{c}\mathrm{R} \$ \\
10.851 .753,09\end{array}$ & $\begin{array}{c}\mathrm{R} \$ \\
3.565 .086,84 \\
\end{array}$ & $\begin{array}{c}\mathrm{R} \$ \\
2.529 .056,80 \\
\end{array}$ & $\begin{array}{c}\mathrm{R} \$ \\
1.606 .010,95 \\
\end{array}$ & $\begin{array}{c}\mathrm{R} \$ \\
824.889,34\end{array}$ \\
\hline $\begin{array}{l}\text { (+) VPL - FLUXO DE BENEFÍCIOS } \\
\text { (RECEBIMENTOS) }\end{array}$ & & & & & \\
\hline Receitas de Direito de Imagem & & & & & \\
\hline Receitas de Licenciamentos & & & & & \\
\hline Outras Receitas & & & & & \\
\hline $\begin{array}{l}(+) \quad \text { VPL } \\
\text { SACRIFÍCIOS (PAGAMENTOS) }\end{array}$ & $\begin{array}{c}\mathrm{R} \$ \\
4.441 .578,77\end{array}$ & $\begin{array}{c}\mathrm{R} \$ \\
1.744 .616,94\end{array}$ & $\begin{array}{c}\mathrm{R} \$ \\
1.479 .725,17\end{array}$ & $\begin{array}{c}\mathrm{R} \$ \\
1.123 .475,19\end{array}$ & $\begin{array}{c}\mathrm{R} \$ \\
689.927,07\end{array}$ \\
\hline Multa Rescisória & $\begin{array}{c}\mathrm{R} \$ \\
2.500 .000,00\end{array}$ & $\begin{array}{c}\mathrm{R} \$ \\
0,00\end{array}$ & $\begin{array}{c}\mathrm{R} \$ \\
0,00\end{array}$ & $\begin{array}{c}\mathrm{R} \$ \\
0,00\end{array}$ & $\begin{array}{c}\mathrm{R} \$ \\
0,00\end{array}$ \\
\hline Salários & $\begin{array}{c}\mathrm{R} \$ \\
1.854 .519,39\end{array}$ & $\begin{array}{c}\mathrm{R} \$ \\
1.666 .389,22\end{array}$ & $\begin{array}{c}\mathrm{R} \$ \\
1.413 .375,06\end{array}$ & $\begin{array}{c}\mathrm{R} \$ \\
1.073 .099,15\end{array}$ & $\begin{array}{c}\mathrm{R} \$ \\
658.991,10\end{array}$ \\
\hline Custos Operacionais - Mensal & $\begin{array}{c}\mathrm{R} \$ \\
26.272,36 \\
\end{array}$ & $\begin{array}{c}\mathrm{R} \$ \\
23.607,18 \\
\end{array}$ & $\begin{array}{c}\mathrm{R} \$ \\
20.022,81 \\
\end{array}$ & $\begin{array}{c}\mathrm{R} \$ \\
15.202,24\end{array}$ & $\begin{array}{c}\mathrm{R} \$ \\
9.335,71\end{array}$ \\
\hline Seguro & $\begin{array}{c}\mathrm{R} \$ \\
51.514,43 \\
\end{array}$ & $\begin{array}{c}\mathrm{R} \$ \\
46.288,59 \\
\end{array}$ & $\begin{array}{c}\mathrm{R} \$ \\
39.260,42 \\
\end{array}$ & $\begin{array}{c}\mathrm{R} \$ \\
29.808,31 \\
\end{array}$ & $\begin{array}{c}\mathrm{R} \$ \\
18.305,31 \\
\end{array}$ \\
\hline Prêmios - Bicho & $\begin{array}{c}\mathrm{R} \$ \\
9.272,60 \\
\end{array}$ & $\begin{array}{c}\mathrm{R} \$ \\
8.331,95 \\
\end{array}$ & $\begin{array}{c}\mathrm{R} \$ \\
7.066,88 \\
\end{array}$ & $\begin{array}{c}\mathrm{R} \$ \\
5.365,50 \\
\end{array}$ & $\begin{array}{c}\mathrm{R} \$ \\
3.294,96 \\
\end{array}$ \\
\hline Prêmios - Finalizações de Camp. & & & & & \\
\hline Outras despesas & & & & & \\
\hline $\begin{array}{l}\text { (+/-) VPL - VALOR PRESENTE } \\
\text { LÍQUIDO }\end{array}$ & $\begin{array}{c}\mathrm{R} \$ \\
4.441 .578,77\end{array}$ & $\begin{array}{c}\mathrm{R} \$ \\
1.744 .616,94\end{array}$ & $\begin{array}{c}\mathrm{R} \$ \\
1.479 .725,17\end{array}$ & $\begin{array}{c}\mathrm{R} \$ \\
1.123 .475,19\end{array}$ & $\begin{array}{c}\mathrm{R} \$ \\
689.927,07\end{array}$ \\
\hline (=) RESULTADO & $\begin{array}{c}\mathrm{R} \$ \\
6.410 .174,32\end{array}$ & $\begin{array}{c}\mathrm{R} \$ \\
1.820 .469,90\end{array}$ & $\begin{array}{c}\mathrm{R} \$ \\
1.049 .331,62\end{array}$ & $\begin{array}{c}\mathrm{R} \$ \\
482.535,75\end{array}$ & $\begin{array}{c}\mathrm{R} \$ \\
134.962,27\end{array}$ \\
\hline
\end{tabular}

Considerações: a partir da simulação do evento apurou-se o resultado de cada período, possibilitando ao gestor avaliar o resultado do evento, tanto por período como pelo resultado global do evento, tendo em vista o tempo estipulado no contrato e a política de contratação do 
clube. A simulação faculta ao gestor acompanhar o desempenho econômico-financeiro do investimento e o retorno mínimo da decisão, em função da escolha feita.

O conceito de custo de oportunidade oferece um parâmetro imprescindível ao gestor na avaliação de sua decisão tendo como parâmetro a melhor alternativa econômica desprezada. Além de avaliar a decisão, o modelo proposto possibilita mensurar nas condições em que se encontra o ativo, qual é o seu valor econômico, conforme as figuras 12 e 13, a seguir.

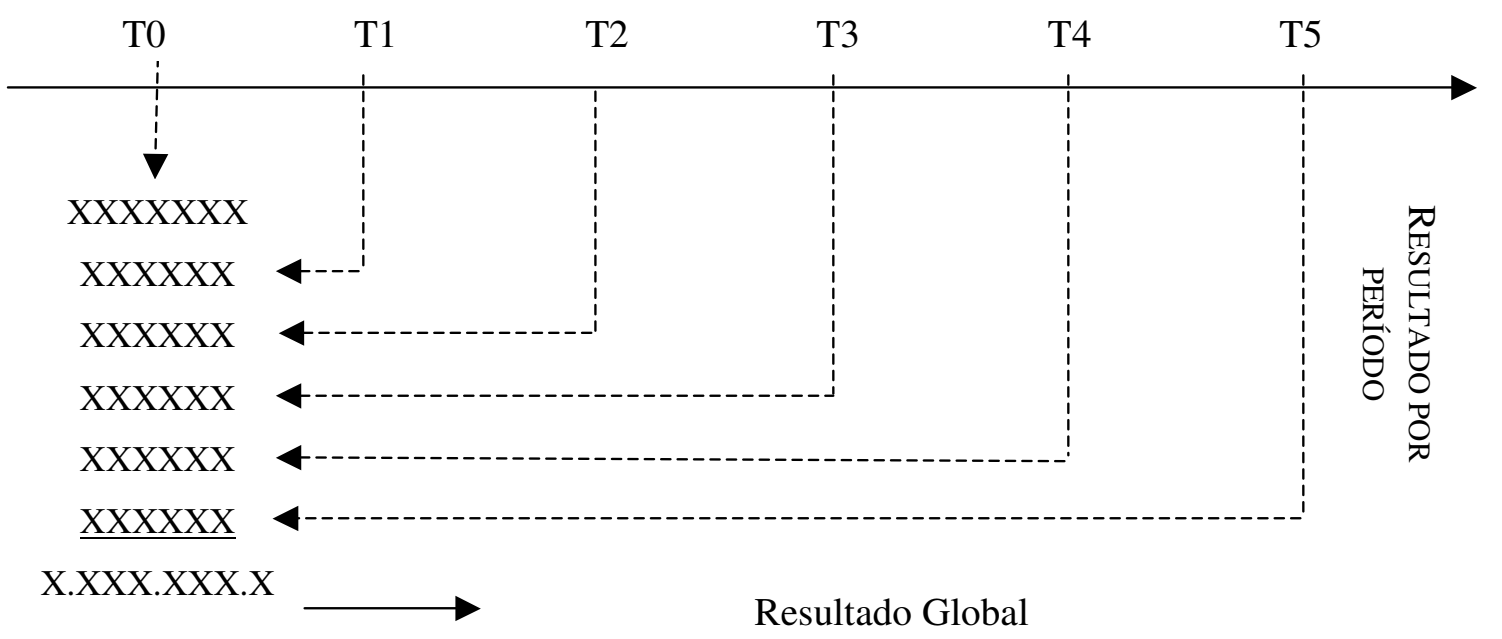

Figura 13 - Fluxo de resultado da decisão em $\mathbf{t}_{0}$

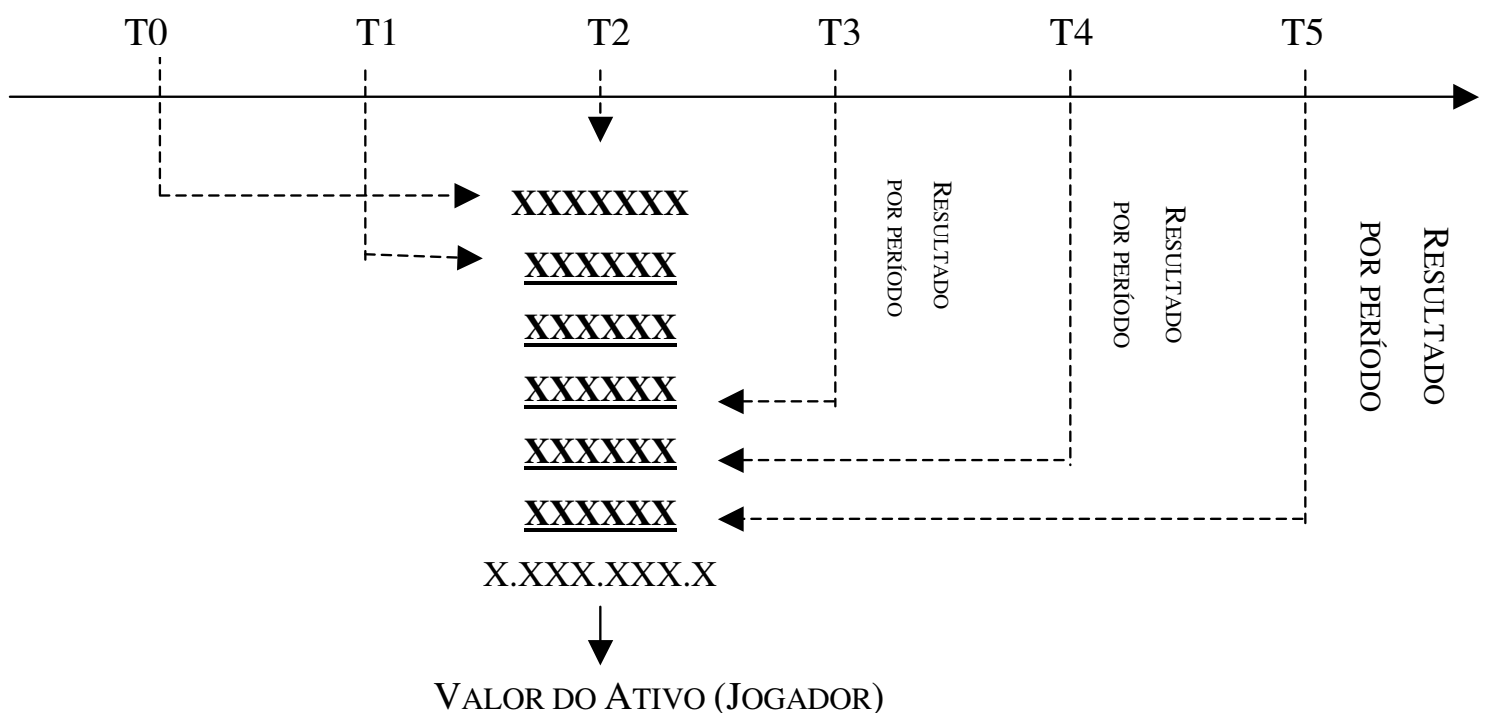

Figura 14 - Fluxo de resultado da decisão em $t_{2}$ 


\subsubsection{Decisão de formação}

\subsubsection{Os atletas formados pelos clubes}

O clube tem a política de investir na formação de atletas, com o objetivo de, no futuro, poder negociá-los com outros clubes. Neste contexto, observa-se que o processo de formação de jogadores consome recursos.

Para detectar e formar um talento é necessário ter muitos praticantes de futebol na fase infantil. Diante das observações realizadas no estudo de caso, pode-se então chegar a algumas constatações preliminares sobre o processo físico-operacional das categorias de base do clube.

Diante de tais observações, acredita-se que uma alternativa viável seria avaliar estes ativos em formação pelo valor presente do fluxo de benefícios futuros. Para tanto, neste estudo, o jogador em formação será tratado como um projeto, com a probabilidade de haver sucesso ou abandono desse projeto.

Com base nos apontamentos estatísticos do departamento científico de futebol, têm-se então as seguintes probabilidades de sucesso (ascensão) e abandono das respectivas categorias de jogadores em formação para cada atleta.

Quadro 5 - Cálculos dos atletas em formação

\begin{tabular}{|lclcccc|}
\hline IDADE & CATEGORIAS & $\begin{array}{c}\text { NÚMERO QUE } \\
\text { ENTRA }\end{array}$ & $\begin{array}{c}\text { NÚMERO } \\
\text { QUE SAI }\end{array}$ & PROBABILIDADE & MÉDIA \\
\hline 07 a 12 & 1. & Núcleos & 15.000 & 100 a 120 & 0,007 a 0,008 & 0,0075 \\
12 a 14 & 2. & Infantil & 100 a 120 & 50 a 60 & 0,50 a 0,60 & 0,55 \\
14 a 16 & 3. & Juvenil & 50 a 60 & 30 a 35 & 0,50 a 0,58 & 0,54 \\
16 a 18 & 4. & Juniores & 30 a 35 & 3 a 4 & 0,09 a 0,11 & 0,10 \\
18 a 20 & 5. & Profissional & 3 a 4 & & & \\
\hline
\end{tabular}

Na teoria da árvore de decisão, elaborou-se um fluxo para cada etapa do projeto (figura 15).

Logo abaixo, apresenta-se uma simulação baseada nas informações coletadas no estudo de caso. Subsidiado na teoria da árvore de decisão, é possível conhecer qual é a probabilidade 
(sucesso ou abandono) para cada atleta em formação. Lembrando que estas simulações foram projetadas com base nos números de atletas que entram e que ascendem a outras categorias, de acordo com as características do clube.

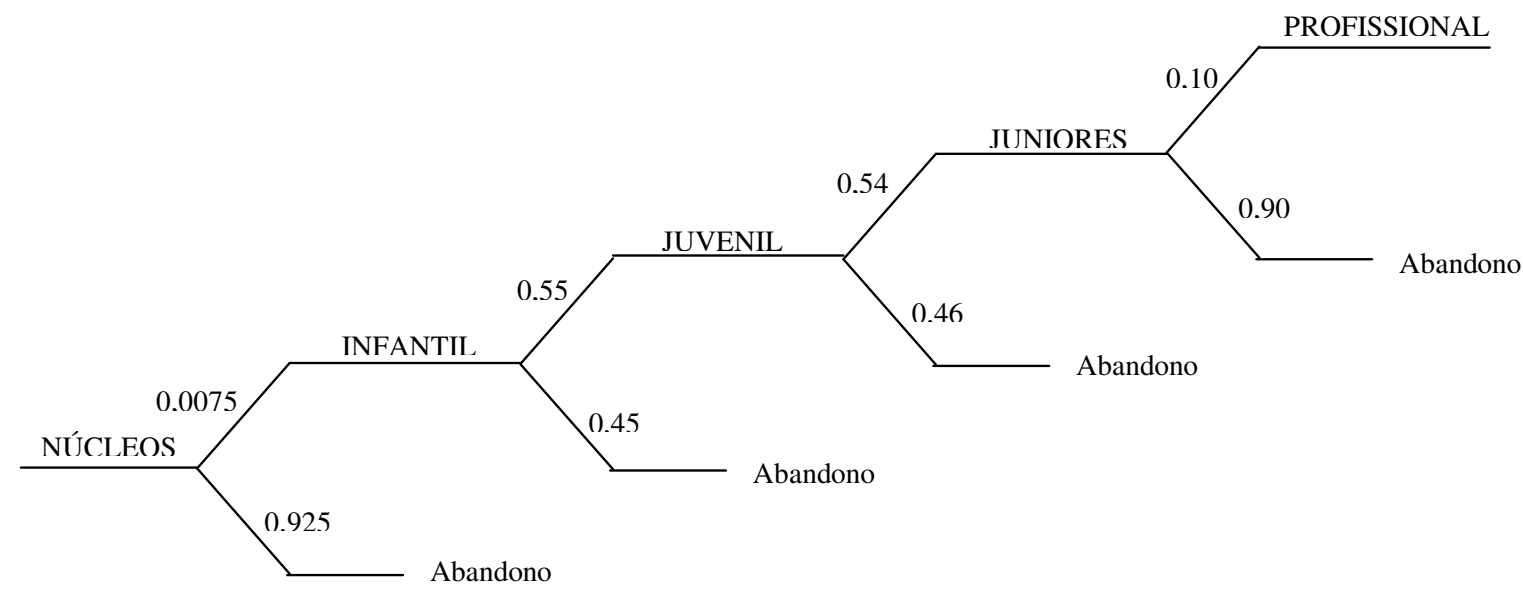

Figura 15 - Árvore de decisão para jogadores em formação

Haja vista a apuração do custo diário e mensal com cada atleta, tem-se um custo diário de $\mathrm{R} \$ 25,00$ a $\mathrm{R}$ \$ 30,00 dia e custo mensal de $\mathrm{R} \$ 750$ a $\mathrm{R} \$ 850$ por mês. Vale ressaltar que não estão inclusos, nestes cálculos, nem salários nem ajuda de custo dos atletas.

Um outro aspecto importante refere-se ao fato de que os atletas profissionais recebem o mesmo tratamento oferecido aos atletas amadores. Ou seja, os custos operacionais diários e mensais são os mesmos tanto para as categorias amadoras, quanto para o profissional. Destaca-se que ambos recebem todo o apoio necessário ao seu desenvolvimento como: material esportivo, assistência educacional, assistência alimentar, assistência médica, assistência odontológica, assistência psicológica e esportiva, além do que os atletas (tanto profissionais quanto amadores) utilizam o sistema de hospedagem do CT. Os atletas amadores também recebem uma ajuda de custos, cujo valor varia conforme a categoria:

- $\quad$ Infantil de $\mathrm{R} \$ 100,00$ por mês;

- Juvenil de $\mathrm{R} \$ 300,00$ por mês; 
- Juniores de $\mathrm{R} \$ 700,00$ por mês.

Deve-se lembrar que este estudo leva em consideração o tempo médio de formação, pois não existe uma faixa (temporal) rígida. Cada atleta tem características fisiológicas diferentes, ou seja, cada atleta corresponde aos treinamentos de maneira diferente.

Diante das estatísticas apontadas pelo departamento científico de futebol, constatou-se que, no período de formação que vai do infantil até os juniores, o atleta permanece em média de 6 a 7 anos.

Quadro 6 - Cálculo de custos - por categoria

\begin{tabular}{|c|c|c|c|c|c|}
\hline IDADE & CATEGORIAS & $\begin{array}{l}\text { CUSTOS } \\
\text { MENSAIS }\end{array}$ & $\begin{array}{l}\text { AJUDA DE } \\
\text { CUSTO }\end{array}$ & $\begin{array}{c}\text { ANOS / MESES } \\
\text { CATEGORIAS }\end{array}$ & TOTAL \\
\hline 12 A 14 & INFANTIL & 850 & R\$ 100,00 & 24 & $22.800,00$ \\
\hline 14 A 16 & JUVENIL & 850 & $\mathbf{R} \$ 300,00$ & 24 & $27.600,00$ \\
\hline 16 A 18 & JUNIORES & 850 & $\mathrm{R} \$ \mathbf{7 0 0 , 0 0}$ & 24 & $37.200,00$ \\
\hline
\end{tabular}

A partir dos cálculos dos custos médios por categoria, elaborou-se um fluxo que relaciona o custo com tempo de cada categoria - que pode ser visto na figura abaixo:

\begin{tabular}{|c|c|c|c|}
$\mathbf{R} \$ 22.800,00$ & $\mathbf{R} \$ 27.600$ & $\mathbf{R} \$ 37.200$ & \\
\hline $\begin{array}{c}\text { 2 Anos } \\
\text { INFANTIL }\end{array}$ & $\begin{array}{c}\text { 2 Anos } \\
\text { JUVENIL }\end{array}$ & $\begin{array}{c}\text { 2 Anos } \\
\text { JUNIORES }\end{array}$ &
\end{tabular}

Figura 16 - Fluxo tempo - custo

De forma semelhante, construiu-se uma árvore de decisão, na qual é possível conhecer qual é o custo e a probabilidade de cada categoria. 


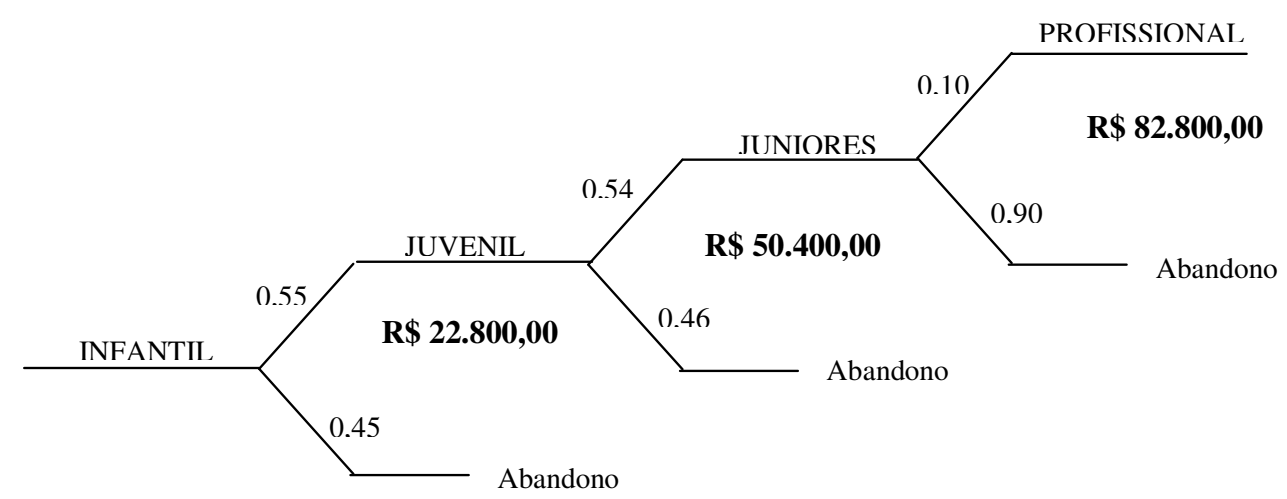

Figura 17 - Árvore de decisão: custos e probabilidade (jogadores em formação)

\subsubsection{Apuração do resultado do evento formação}

Diante do processamento das variáveis em consonância com os conceitos do modelo de mensuração, apurou-se o resultado do evento formação pode ser visto no quadro a seguir.

Quadro 7 - Decisão de formação

\begin{tabular}{|c|c|c|c|c|}
\hline \multicolumn{5}{|c|}{ MODELO DE MENSURAÇÃO } \\
\hline & \multicolumn{2}{|c|}{ Período: 24 meses por categoria } & \multicolumn{2}{|c|}{ Evento: Formação } \\
\hline CONTAS & INFANTIL & JUVENIL & JUNIORES & TOTAL \\
\hline (+) RECEITA DE OPORTUNIDADE & $\begin{array}{c}\mathrm{R} \$ \\
4.963 .262,53 \\
\end{array}$ & $\begin{array}{c}\mathrm{R} \$ \\
2.521 .783,04\end{array}$ & $\begin{array}{c}\mathrm{R} \$ \\
1.386 .990,09\end{array}$ & $\begin{array}{c}\mathrm{R} \$ \\
7.822 .679,56\end{array}$ \\
\hline $\begin{array}{l}\text { (+) VPL - FLUXO DE BENEFÍCIOS } \\
\text { (RECEBIMENTOS) }\end{array}$ & & & & \\
\hline Receitas de Direito de Imagem & & & & \\
\hline Receitas de Licenciamentos & & & & \\
\hline Outras Receitas & & & & \\
\hline $\begin{array}{l}\text { (+) VPL - FLUXO DE SACRIFÍCIOS } \\
\text { (PAGAMENTOS) }\end{array}$ & \begin{tabular}{|c|}
$\mathrm{R} \$$ \\
$1.699 .073,65$ \\
\end{tabular} & $\begin{array}{c}\mathrm{R} \$ \\
1.234 .064,02 \\
\end{array}$ & $\begin{array}{c}\mathrm{R} \$ \\
970.260,48 \\
\end{array}$ & $\begin{array}{c}\mathrm{R} \$ \\
3.903 .398,16 \\
\end{array}$ \\
\hline Multa Rescisória & & & & \\
\hline Salários (Bolsa) & $\begin{array}{c}\mathrm{R} \$ \\
178.849,86\end{array}$ & $\begin{array}{c}\mathrm{R} \$ \\
321.929,74\end{array}$ & $\begin{array}{c}\mathrm{R} \$ \\
438.182,15\end{array}$ & $\begin{array}{c}\mathrm{R} \$ \\
938.961,76\end{array}$ \\
\hline Custos Operacionais - Mensal & $\begin{array}{c}\mathrm{R} \$ \\
1.520 .223,80 \\
\end{array}$ & $\begin{array}{c}\mathrm{R} \$ \\
912.134,28 \\
\end{array}$ & $\begin{array}{c}\mathrm{R} \$ \\
532.078,33 \\
\end{array}$ & $\begin{array}{c}\mathrm{R} \$ \\
2.964 .436,40 \\
\end{array}$ \\
\hline Seguro & & & & \\
\hline Prêmios - Bicho & & & & \\
\hline Prêmios - Finalizações de Camp. & & & & \\
\hline Outras despesas & & & & \\
\hline $\begin{array}{l}\text { (+/-) VPL - VALOR PRESENTE } \\
\text { LÍQUIDO }\end{array}$ & $\begin{array}{c}\mathrm{R} \$ \\
1.699 .073,65\end{array}$ & $\begin{array}{c}\mathrm{R} \$ \\
1.234 .064,02\end{array}$ & $\begin{array}{c}\mathrm{R} \$ \\
970.260,48\end{array}$ & $\begin{array}{c}\mathrm{R} \$ \\
3.903 .398,16\end{array}$ \\
\hline (=) RESULTADO & $\begin{array}{c}\mathrm{R} \$ \\
3.264 .188,88 \\
\end{array}$ & $\begin{array}{c}\mathrm{R} \$ \\
1.287 .719,02 \\
\end{array}$ & $\begin{array}{c}\mathrm{R} \$ \\
416.729,61 \\
\end{array}$ & $\begin{array}{c}\mathrm{R} \$ \\
3.919 .281,40 \\
\end{array}$ \\
\hline
\end{tabular}


Obs. deve ressaltar que as taxas de desconto e aplicação utilizadas nessa simulação são as mesmas taxas utilizadas nas demais simulações.

Considerações: a aplicação do modelo de mensuração ao evento formação permite ao gestor uma avaliação econômica:

- $\quad$ por categoria;

- $\quad$ por lote (todo projeto);

- $\quad$ por atleta em formação.

Além disso, a simulação baseada na árvore de decisão demonstra qual é a viabilidade, qual a probabilidade (sucesso ou abandono) da decisão, pois o modelo de mensuração leva em consideração o ganho desprezado em função da escolha feita.

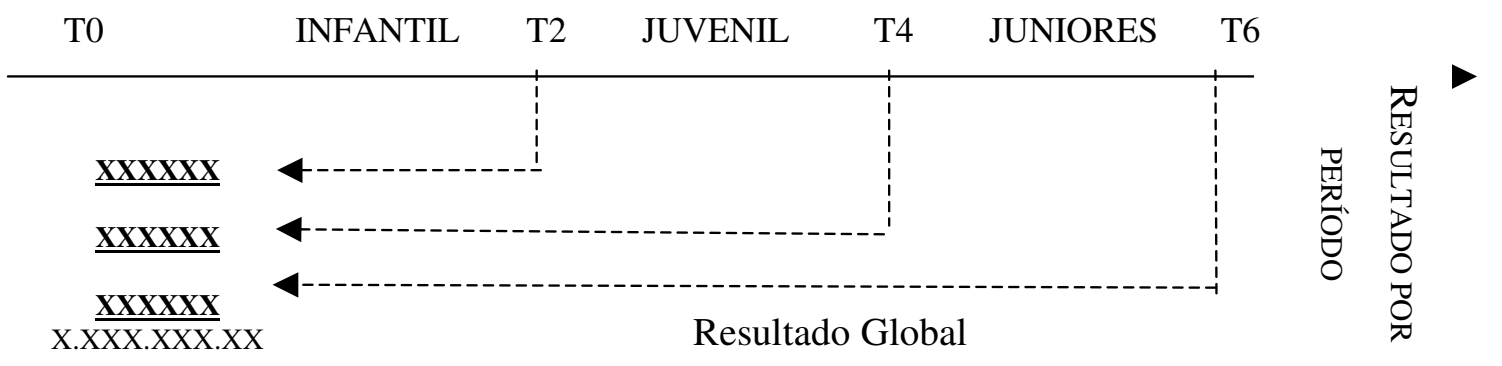

Figura 18 - Fluxo da apuração do resultado do evento - formação

Equação: Valor de Mercado > = Resultado + Custo de formação (VPL - sacrifícios), ou seja, Prováveis Receitas (Benefícios futuros) $>=$ Resultado econômico + Custo de formação (VPL - sacrifícios).

O estudo de caso apontou constatações importantes, pois para cada 4 atletas revelados (ascendem) ao profissional é necessário haver entre 100 a 120 atletas na categoria infantil.

Portanto, o valor de mercado dos atletas formados tem de ser maior que o custo de formação de todos os atletas com sucesso mais abandonos, para que esse negócio seja viável. 


\subsubsection{Decisão de permuta}

Este tipo de evento não é muito praticado pelos clubes, entretanto as decisões de troca de atletas acontecem quando vai jogador "A" e vem jogador "B", e geralmente não envolvem desembolso (multa rescisória). O modelo de mensuração proposto possibilita ao gestor avaliar o impacto econômico desta decisão.

\subsubsection{Características do evento}

O Clube Atlético de Futebol - USP: resolveu trocar um atleta (Jogador A) que se encontrava na equipe principal, na condição de reserva, com outro clube, recebendo um jogador equivalente em termos de: performance esportiva, idade. Observou-se apenas diferença relevante na variável salário. O clube tem uma política de fechar contratos por um período de 5 anos. Foram apontadas as variáveis que são consideradas pelos gestores como relevantes ao processo de negociação, tendo em vista que o clube irá participar dos seguintes campeonatos descritos abaixo:

\subsubsection{Variáveis identificadas}

Condições Econômicas

Tempo de Contrato

Recebimento inicial

Desembolso Inicial (Multa Rescisória)

Custos Operacionais

Salários propostos

Seguro

Prêmio bicho

Prêmios (Final de Campeonato)

Direito de Imagem
Jogador A

5

$\mathrm{R} \$$

$\mathrm{R} \$ 850,00$

$\mathrm{R} \$ 15.000,00$

$\mathrm{R} \$ 20.000,00$

$\mathrm{R} \$ \quad 300,00$

$?$

?
Jogador B

5

$\mathrm{R} \$$

$\mathrm{R} \$ 850,00$

$\mathrm{R} \$ 20.000,00$

$\mathrm{R} \$ 20.000,00$

$\mathrm{R} \$ \quad 300,00$

$?$

$?$

20

10

46

10
Condição

Anos

Moeda

Mensal

Mensal

Anual

p/ vitória

N. Ident.

N. Ident.

\section{Condições Esportivas:}

Campeonatos Estaduais

Campeonatos Nacionais - Brasileiro

Outros jogos (amistosos)

\section{(}

jogos

jogos

jogos

jogos 
Condições Financeiras

$\begin{array}{lll}\text { Taxa de Desconto (custo oportunidade) } & 2,50 \% & \text { Ao mês }\end{array}$

$\begin{array}{lll}\text { Taxa de Aplicação (custo oportunidade) } & 1,50 \% & \text { Ao mês }\end{array}$

\subsubsection{Apuração do resultado do evento permuta}

Diante do processamento das variáveis em consonância com os conceitos do modelo de mensuração, apurou-se o resultado do evento que pode ser visto no quadro abaixo.

Quadro 8 - Decisão de permuta - jogador A

\begin{tabular}{|c|c|c|c|c|c|}
\hline \multicolumn{6}{|c|}{ MODELO DE MENSURAÇÃO } \\
\hline & \multicolumn{2}{|c|}{ Período: 60 meses } & \multicolumn{3}{|c|}{ Evento: Permuta - jogador A } \\
\hline CONTAS & Período 01 & Período 02 & Período 03 & Período 04 & Período 05 \\
\hline $\begin{array}{l}\text { (+) RECEITA DE } \\
\text { OPORTUNIDADE }\end{array}$ & $\mathrm{R} \$ 1.345 .454,82$ & $\mathrm{R} \$ 1.011 .164,19$ & $\mathrm{R} \$ 717.315,39$ & $\mathrm{R} \$ 455.512,26$ & $\mathrm{R} \$ 233.963,04$ \\
\hline $\begin{array}{l}\text { (+) VPL - FLUXO DE } \\
\text { BENEFÍCIOS } \\
\text { (RECEBIMENTOS) }\end{array}$ & & & & & \\
\hline $\begin{array}{l}\text { Receitas de Direito de } \\
\text { Imagem }\end{array}$ & & & & & \\
\hline $\begin{array}{l}\text { Receitas de } \\
\text { Licenciamentos }\end{array}$ & & & & & \\
\hline Outras Receitas & & & & & \\
\hline $\begin{array}{l}\text { (+) VPL - FLUXO DE } \\
\text { SACRIFÍCIOS } \\
\text { (PAGAMENTOS) }\end{array}$ & $\mathrm{R} \$ 550.689,23$ & $\mathrm{R} \$ 494.825,02$ & $\mathrm{R} \$ 419.693,87$ & $\mathrm{R} \$ 318.650,83$ & $\mathrm{R} \$ 195.683,75$ \\
\hline Multa Rescisória & & & & & \\
\hline Salários & $\mathrm{R} \$ 463.629,85$ & $\mathrm{R} \$ 416.597,31$ & $\mathrm{R} \$ 353.343,77$ & $\mathrm{R} \$ 268.274,79$ & $\mathrm{R} \$ 164.747,77$ \\
\hline $\begin{array}{l}\text { Custos Operacionais - } \\
\text { Mensal }\end{array}$ & $\mathrm{R} \$ 26.272,36$ & $\mathrm{R} \$ 23.607,18$ & $\mathrm{R} \$ 20.022,81$ & $\mathrm{R} \$ 15.202,24$ & $\mathrm{R} \$ 9.335,71$ \\
\hline Seguro & $\mathrm{R} \$ 51.514,43$ & $\mathrm{R} \$ 46.288,59$ & $\mathrm{R} \$ 39.260,42$ & $\mathrm{R} \$ 29.808,31$ & $\mathrm{R} \$ 18.305,31$ \\
\hline Prêmios - Bicho & $\mathrm{R} \$ 9.272,60$ & $\mathrm{R} \$ 8.331,95$ & $\mathrm{R} \$ 7.066,88$ & $\mathrm{R} \$ 5.365,50$ & $\mathrm{R} \$ 3.294,96$ \\
\hline $\begin{array}{l}\text { Prêmios - Finalizações } \\
\text { de Camp. }\end{array}$ & & & & & \\
\hline Outras despesas & & & & & \\
\hline $\begin{array}{l}\text { (+/-) VPL - VALOR } \\
\text { PRESENTE LÍQUIDO }\end{array}$ & $\mathrm{R} \$ 550.689,23$ & $\mathrm{R} \$ 494.825,02$ & $\mathrm{R} \$ 419.693,87$ & $\mathrm{R} \$ 318.650,83$ & $\mathrm{R} \$ 195.683,75$ \\
\hline (=) RESULTADO & $\mathrm{R} \$ 794.765,59$ & $\mathrm{R} \$ 516.339,17$ & $\mathrm{R} \$ 297.621,52$ & $\mathrm{R} \$ 136.861,43$ & $\mathrm{R} \$ 38.279,30$ \\
\hline
\end{tabular}


Quadro 9 - Decisão de permuta - jogador B

\begin{tabular}{|l|c|c|c|c|c|}
\hline \multicolumn{7}{|c|}{ MODELO DE MENSURAÇÃO } \\
\hline & \multicolumn{2}{|c|}{ Período: 60 meses } & \multicolumn{2}{c|}{ Evento: Permuta - jogador B } \\
\hline CONTAS & Período 01 & Período 02 & Período 03 & Período 04 & Período 05 \\
\hline $\begin{array}{l}\text { (+) RECEITA DE } \\
\text { OPORTUNIDADE }\end{array}$ & $\mathrm{R} \$ 1.723 .038,02$ & $\mathrm{R} \$ 1.294 .933,37$ & $\mathrm{R} \$ 918.619,99$ & $\mathrm{R} \$ 583.345,45$ & $\mathrm{R} \$ 299.621,52$ \\
\hline $\begin{array}{l}\text { (+) VPL - FLUXO DE } \\
\text { BENEFÍCIOS } \\
\text { (RECEBIMENTOS) }\end{array}$ & & & & & \\
\hline $\begin{array}{l}\text { Receitas de Direito de } \\
\text { Imagem }\end{array}$ & & & & & \\
\hline $\begin{array}{l}\text { Receitas de } \\
\text { Licenciamentos }\end{array}$ & & & & & \\
\hline Outras Receitas & & & & & \\
\hline $\begin{array}{l}\text { (+) VPL - FLUXO DE } \\
\text { SACRIFÍCIOS } \\
\text { (PAGAMENTOS) }\end{array}$ & $\mathrm{R} \$ 705.232,51$ & $\mathrm{R} \$ 633.690,79$ & $\mathrm{R} \$ 537.475,13$ & $\mathrm{R} \$ 408.075,76$ & $\mathrm{R} \$ 250.599,67$ \\
\hline Multa Rescisória & $\mathbf{0}$ & $\mathbf{0}$ & $\mathbf{0}$ & $\mathbf{0}$ & $\mathbf{0}$ \\
\hline Salários & $\mathrm{R} \$ 618.173,13$ & $\mathrm{R} \$ 555.463,07$ & $\mathrm{R} \$ 471.125,02$ & $\mathrm{R} \$ 357.699,72$ & $\mathrm{R} \$ 219.663,70$ \\
\hline $\begin{array}{l}\text { Custos Operacionais - } \\
\text { Mensal }\end{array}$ & $\mathrm{R} \$ 26.272,36$ & $\mathrm{R} \$ 23.607,18$ & $\mathrm{R} \$ 20.022,81$ & $\mathrm{R} \$ 15.202,24$ & $\mathrm{R} \$ 9.335,71$ \\
\hline Seguro & $\mathrm{R} \$ 51.514,43$ & $\mathrm{R} \$ 46.288,59$ & $\mathrm{R} \$ 39.260,42$ & $\mathrm{R} \$ 29.808,31$ & $\mathrm{R} \$ 18.305,31$ \\
\hline Prêmios - Bicho & $\mathrm{R} \$ 9.272,60$ & $\mathrm{R} \$ 8.331,95$ & $\mathrm{R} \$ 7.066,88$ & $\mathrm{R} \$ 5.365,50$ & $\mathrm{R} \$ 3.294,96$ \\
\hline $\begin{array}{l}\text { Prêmios - Finalizações } \\
\text { de Camp. }\end{array}$ & & & & & \\
\hline Outras despesas & & & & & \\
\hline $\begin{array}{l}\text { (+/-) VPL - VALOR } \\
\text { PRESENTE LÍQUIDO }\end{array}$ & $\mathrm{R} \$ 705.232,51$ & $\mathrm{R} \$ 633.690,79$ & $\mathrm{R} \$ 537.475,13$ & $\mathrm{R} \$ 408.075,76$ & $\mathrm{R} \$ 250.599,67$ \\
\hline \begin{tabular}{l} 
(=) RESULTADO \\
\hline
\end{tabular} & $\mathrm{R} \$ 1.017 .805,51$ & $\mathrm{R} \$ 661.242,58$ & $\mathrm{R} \$ 381.144,86$ & $\mathrm{R} \$ 175.269,69$ & $\mathrm{R} \$ 49.021,85$ \\
\hline
\end{tabular}

Considerações: observou-se que a troca (permuta) do jogador A do Clube Atlético de Futebol USP pelo jogador B gerou impacto econômico significativo, como pode ser observado nos resultados apurados apresentados no Quadro 8 quando comparados com o Quadro 9. A decisão de troca traria ao clube uma economia (em termos de desembolso), ou seja, gerando um impacto econômico tanto no resultado como no patrimônio do clube.

Equação: Resultado do Evento $<=$ VPL (desembolso) jogador trocado

\subsubsection{Decisão de empréstimo (obtenção)}

Os clubes brasileiros, diante do momento econômico (crise do futebol), buscam alternativas como a obtenção de jogadores sob a condição de empréstimo, estes tipos de decisão são largamente utilizados, não somente no âmbito nacional, como no internacional também. 


\subsubsection{Características do evento}

O Clube Atlético de Futebol - USP decidiu obter o atleta solicitado pela comissão técnica sob a condição de empréstimo. A política dos clubes no tocante a empréstimos é de um ano. Após verificar no mercado de jogadores encontrou o jogador desejado, bem como as variáveis descritas abaixo foram apontadas pelos gestores como relevantes ao processo de negociação, tendo em vista que o clube irá participar dos campeonatos descritos a seguir:

\subsubsection{Variáveis identificadas}

Condições Econômicas Jogador A Condição

Tempo de Contrato 01 anos

Recebimento inicial

Desembolso Inicial (Multa Rescisória)

R\$ 500.000,00 Moeda

Custos Operacionais

$\mathrm{R} \$ \quad 850,00 \quad$ mensal

Salários propostos

$\mathrm{R} \$ 15.000,00$ mensal

Seguro

$\mathrm{R} \$ \quad 20.000,00 \quad$ anual

Prêmio bicho

$\mathrm{R} \$ \quad 300,00$

$\mathrm{p} /$ vitória

Prêmios (final de campeonato)

?

Não Ident.

Direito de Imagem

Não Ident.

\section{Condições Esportivas:}

Campeonatos Estaduais 20

jogos

Campeonatos Regionais

10

jogos

Campeonatos Nacionais - Brasileiro

46

Outros jogos (amistosos)

10

jogos

jogos

Condições Financeiras

Taxa de Desconto

Taxa de Aplicação (custo oportunidade)
$2,50 \%$

$1,50 \%$ ao mês

ao mês

\subsubsection{Apuração do resultado do evento obtenção de empréstimo}

Diante do processamento das variáveis em consonância com os conceitos do modelo de mensuração, apurou-se o resultado do evento que pode ser visto no quadro abaixo. 
Quadro 10 - Decisão de empréstimo (obtenção)

\begin{tabular}{|c|c|c|}
\hline \multicolumn{3}{|c|}{ MODELO DE MENSURAÇÃO } \\
\hline & \multicolumn{2}{|c|}{ Evento: Empréstimo Obtenção } \\
\hline CONTAS & Período 01 & Total \\
\hline (+) RECEITA DE OPORTUNIDADE & $\mathrm{R} \$ 1.668 .130,71$ & $\mathrm{R} \$ 1.668 .130,71$ \\
\hline \multicolumn{3}{|l|}{ (+) VPL - FLUXO DE BENEFÍCIOS (RECEBIMENTOS) } \\
\hline \multicolumn{3}{|l|}{ Receitas de Direito de Imagem } \\
\hline \multicolumn{3}{|l|}{ Receitas de Licenciamentos } \\
\hline \multicolumn{3}{|l|}{ Outras Receitas } \\
\hline (+) VPL - FLUXO DE SACRIFÍCIOS (PAGAMENTOS) & $\mathrm{R} \$ \quad 682.759,17$ & $\mathrm{R} \$ 682.759,17$ \\
\hline Multa Rescisória & $\mathbf{R} \$ \mathbf{5 0 0 . 0 0 0 , 0 0}$ & $\mathrm{R} \$ 500.000,00$ \\
\hline Salários & R\$ $153.866,47$ & $\mathrm{R} \$ 153.866,47$ \\
\hline Custos Operacionais - Mensal & $\mathbf{R} \$ \quad \mathbf{8 . 7 1 9 , 1 0}$ & $\mathrm{R} \$ \quad 8.719,10$ \\
\hline Seguro & R\$ $\quad 17.096,27$ & $\mathrm{R} \$ 17.096,27$ \\
\hline Prêmios - Bicho & $\mathbf{3 . 0 7 7 , 3 3}$ & $\mathrm{R} \$ 3.077,33$ \\
\hline \multicolumn{3}{|l|}{ Prêmios - Finalizações de Camp. } \\
\hline \multicolumn{3}{|l|}{ Outras despesas } \\
\hline (+/-) VPL - VALOR PRESENTE LÍQUIDO & $\mathrm{R} \$ 682.759,17$ & $\mathrm{R} \$ 682.759,17$ \\
\hline (=) RESULTADO & $\mathrm{R} \$ 985.371,54$ & $\mathrm{R} \$ 985.371,54$ \\
\hline
\end{tabular}

Considerações: De acordo com o resultado apurado pelo modelo de mensuração, observou-se que a obtenção do empréstimo do respectivo jogador teria de gerar um resultado de R\$ 967.771,30, no mínimo, para que a alternativa desprezada fosse viável.

Equação: Resultado do Evento $>=$ Receita de Oportunidade - VPL (desembolso).

ou

Valor pago pelo Empréstimo $<=$ Receita de oportunidade - Somatório dos Desembolsos para adquirir mais salários trazidos a VPL.

\subsubsection{Decisão de empréstimo (concessão)}

Tanto os clubes brasileiros como os clubes internacionais, habitualmente, tomam decisão de concessão de jogadores sob a forma de empréstimo, e podem ou não receber alguma quantia pelo negócio. Estes empréstimos acontecem pelo fato de os clubes não conseguirem absorver todos os jogadores formados, ou pelo fato de o atleta não se adequar à filosofia do clube. 


\subsubsection{Características do evento}

O Clube Atlético de Futebol - USP resolveu conceder um atleta que não se enquadrou ao esquema tático da comissão técnica, sob a condição de empréstimo. A política do clube, no tocante à concessão de empréstimos, é por um período de um ano. Foram apontadas as variáveis que são consideradas pelos gestores como relevantes ao processo de negociação, tendo em vista, que o clube irá participar dos campeonatos descritos na seqüência:

\subsubsection{Variáveis identificadas}

Condições Econômicas

Jogador A

Tempo de Contrato

Recebimento inicial

Desembolso Inicial (Multa Rescisória)

Custos Operacionais

Salários propostos

Seguro

Prêmio bicho

Prêmio Final de Campeonato

Direito de Imagem

1

1

$\mathrm{R} \$ \quad 300.000,00$

$\mathrm{R} \$$ - moeda

$\mathrm{R} \$ \quad 850,00$ mensal

$\mathrm{R} \$ \quad 15.000,00$ mensal

R\$ 20.000,00 anual

$\mathrm{R} \$ \quad 300,00 \quad \mathrm{p} /$ vitória

? Não Ident.

? Não Ident.

\section{Condições Esportivas:}

Campeonatos Estaduais 20

jogos

Campeonatos Regionais

10

jogos

Campeonatos Nacionais - Brasileiro

46

jogos

Outros jogos (amistosos)

10

jogos

Condições Financeiras

Taxa de Desconto (custo oportunidade) $2,50 \%$

ao mês

Taxa de Aplicação (custo oportunidade)

$1,50 \%$

ao mês 


\subsubsection{Apuração do resultado do evento concessão de empréstimo}

Diante do processamento das variáveis em consonância com os conceitos do modelo de mensuração, apurou-se o resultado do evento empréstimo (concessão) que pode ser visto no quadro 11 , a seguir.

Quadro 11 - Decisão de empréstimo (concessão)

\begin{tabular}{|c|c|c|}
\hline \multicolumn{3}{|c|}{ MODELO DE MENSURAÇÃO } \\
\hline & \multicolumn{2}{|c|}{ Evento: Empréstimo concessão } \\
\hline CONTAS & Período 01 & Total \\
\hline (+) RECEITA DE OPORTUNIDADE & $\mathrm{R} \$ 218.510,19$ & $\mathrm{R} \$ 218.510,19$ \\
\hline (+) VPL - FLUXO DE BENEFÍCIOS (RECEBIMENTOS) & $\mathrm{R} \$ 300.000,00$ & $\mathrm{R} \$ 300.000,00$ \\
\hline Receitas de Direito de Imagem & & \\
\hline Receitas de Licenciamentos & & \\
\hline Outras Receitas & & \\
\hline (+) VPL - FLUXO DE SACRIFÍCIOS (PAGAMENTOS) & $(\mathrm{R} \$ 182.759,17)$ & $(\mathrm{R} \$ 182.759,17)$ \\
\hline Multa Rescisória & & \\
\hline Salários & $(\mathrm{R} \$ 153.866,47)$ & $(\mathrm{R} \$ 153.866,47)$ \\
\hline Custos Operacionais - Mensal & $(\mathrm{R} \$ 8.719,10)$ & $(\mathrm{R} \$ 8.719,10)$ \\
\hline Seguro & $(\mathrm{R} \$ 17.096,27)$ & $(\mathrm{R} \$ 17.096,27)$ \\
\hline Prêmios - Bicho & $(\mathrm{R} \$ 3.077,33)$ & $(\mathrm{R} \$ 3.077,33)$ \\
\hline Prêmios - Finalizações de Camp. & & \\
\hline Outras despesas & & \\
\hline (+/-) VPL - VALOR PRESENTE LÍQUIDO & $(\mathrm{R} \$ 182.759,17)$ & $(\mathrm{R} \$ 182.759,17)$ \\
\hline (=) RESULTADO & $\mathrm{R} \$ 35.751,02$ & $\mathrm{R} \$ 35.751,02$ \\
\hline RESULTADO (LUCRO / PREJUÍZO) DA TRANSAÇÃO & $\mathrm{R} \$ 81.489,81$ & $\mathrm{R} \$ 81.489,81$ \\
\hline
\end{tabular}

Considerações: observou-se que a decisão de empréstimo gerou um resultado de $\mathrm{R}$ \$ 35.751,01 e, em conseqüência, um lucro de $\mathrm{R} \$ 81.489,81$. de acordo com o modelo de mensuração.

Equação: Valor recebido $>=$ Receita de Oportunidade - Somatório dos Desembolsos trazidos a VPL. 


\subsubsection{Decisão de venda}

Dentre as decisões apresentadas anteriormente, a decisão de negociar atletas com outros clubes representa uma das mais praticadas. Geralmente decorre pelas seguintes razões: necessidades financeiras do clube; política da comissão técnica, o atleta não atende as necessidades esportivas do clube; o atleta não se enquadra à filosofia do clube; valor de mercado ofertado pelo jogador é maior do que seu valor econômico para o clube.

O modelo de mensuração proposto possibilita ao gestor avaliar o impacto econômico desta decisão.

\subsubsection{Características do evento}

O Clube Atlético de Futebol - USP: resolveu vender um atleta que se encontrava na equipe principal na condição de reserva.

\subsubsection{Variáveis identificadas}

Condições Econômicas Jogador A Condição

Valores Hipotéticos de vendas:

$\begin{array}{lllll}\text { Período } 01 & \text { Período } 02 & \text { Período } 03 & \text { Período } 04 & \text { Período } 05\end{array}$

VALORES

OFERTADOS

$\mathrm{R} \$ 551.000,00$

$\mathrm{R} \$ 500.000,00$

$\mathrm{R} \$ 420.000,00$

$\mathrm{R} \$ 320.000,00$

$\mathrm{R} \$ 200.000,00$

Tempo de Contrato

5

Anos

Recebimento inicial

Desembolso Inicial (Multa Rescisória)

$\mathrm{R} \$$

Moeda

Custos Operacionais

R\$ 850,00 Mensal

Salários propostos

R\$ 15.000,00 Mensal

Seguro

$\mathrm{R} \$ 20.000,00 \quad$ Anual

Prêmio bicho

Prêmios (Final de Campeonato)

$\mathrm{R} \$ \quad 300,00 \quad \mathrm{p} /$ vitória

Direito de Imagem

Não Identificado

? Não Identificado 
Condições Esportivas:

$\begin{array}{lll}\text { Campeonatos Estaduais } & 20 & \text { jogos } \\ \text { Campeonatos Regionais } & 10 & \text { jogos } \\ \text { Campeonatos Nacionais - Brasileiro } & 46 & \text { jogos } \\ \text { Outros jogos (amistosos) } & 10 & \text { jogos }\end{array}$

Condições Financeiras

Taxa de Desconto 2,50\% Ao mês

Taxa de Aplicação (custo oportunidade) $\quad 1,50 \% \quad$ Ao mês

\subsubsection{Apuração do resultado do evento venda}

Diante do processamento das variáveis em consonância com os conceitos do modelo de mensuração, apurou-se o resultado do evento que pode ser visto no quadro abaixo. Deste modo, apresenta uma simulação que demonstra qual o resultado esperado da transação a cada período. 
Quadro 12 - Decisão de Venda

\begin{tabular}{|c|c|c|c|c|c|}
\hline \multicolumn{6}{|c|}{ MODELO DE MENSURAÇÃO } \\
\hline & \multicolumn{2}{|c|}{ Período: 60 meses } & \multicolumn{3}{|c|}{ Evento: Venda } \\
\hline CONTAS & Período 01 & Período 02 & Período 03 & Período 04 & Período 05 \\
\hline $\begin{array}{l}\text { (+) RECEITA DE } \\
\text { OPORTUNIDADE } \\
\end{array}$ & $\mathrm{R} \$ 1.345 .454,82$ & $\mathrm{R} \$ 1.011 .164,19$ & $\mathrm{R} \$ 717.315,39$ & $\mathrm{R} \$ 455.512,26$ & $\mathrm{R} \$ 233.963,04$ \\
\hline $\begin{array}{l}\text { (+) VPL - FLUXO } \\
\text { DE BENEFICIOS } \\
\text { (RECEBIMENTOS) }\end{array}$ & $\begin{array}{c}\mathrm{R} \$ \\
551.000,00\end{array}$ & $\begin{array}{c}\mathrm{R} \$ \\
500.000,00\end{array}$ & $\begin{array}{c}\mathrm{R} \$ \\
420.000,00\end{array}$ & $\begin{array}{l}\mathrm{R} \$ \\
320.000,00\end{array}$ & $\begin{array}{c}\mathrm{R} \$ \\
200.000,00\end{array}$ \\
\hline $\begin{array}{l}\text { Receitas de Direito } \\
\text { de Imagem }\end{array}$ & & & & & \\
\hline $\begin{array}{l}\text { Receitas de } \\
\text { Licenciamentos }\end{array}$ & & & & & \\
\hline Outras Receitas & & & & & \\
\hline $\begin{array}{l}\text { (+) VPL - FLUXO } \\
\text { DE SACRIFICIOS } \\
\text { (PAGAMENTOS) } \\
\end{array}$ & $\mathrm{R} \$ 550.689,23$ & $\mathrm{R} \$ 494.825,02$ & $\mathrm{R} \$ 419.693,87$ & $\mathrm{R} \$ 318.650,83$ & $\mathrm{R} \$ 195.683,75$ \\
\hline Multa Rescisória & 0 & 0 & 0 & 0 & 0 \\
\hline Salários & $\mathrm{R} \$ 463.629,85$ & $\mathrm{R} \$ 416.597,31$ & $\mathrm{R} \$ 353.343,77$ & $\mathrm{R} \$ 268.274,79$ & $\mathrm{R} \$ 164.747,77$ \\
\hline $\begin{array}{l}\text { Custos Operacionais } \\
\text { - Mensal }\end{array}$ & $\mathrm{R} \$ 26.272,36$ & $\mathrm{R} \$ 23.607,18$ & $\mathrm{R} \$ 20.022,81$ & $\mathrm{R} \$ 15.202,24$ & $\mathrm{R} \$ 9.335,71$ \\
\hline Seguro & $\mathrm{R} \$ 51.514,43$ & $\mathrm{R} \$ 46.288,59$ & $\mathrm{R} \$ 39.260,42$ & $\mathrm{R} \$ 29.808,31$ & $\mathrm{R} \$ 18.305,31$ \\
\hline Prêmios - Bicho & $\mathrm{R} \$ 9.272,60$ & $\mathrm{R} \$ 8.331,95$ & $\mathrm{R} \$ 7.066,88$ & $\mathrm{R} \$ 5.365,50$ & $\mathrm{R} \$ 3.294,96$ \\
\hline $\begin{array}{l}\text { Prêmios - } \\
\text { Finalizações de } \\
\text { Camp. }\end{array}$ & & & & & \\
\hline Outras despesas & & & & & \\
\hline $\begin{array}{l}\text { (+/-) VPL - VALOR } \\
\text { PRESENTE } \\
\text { LÍQUIDO }\end{array}$ & $\mathrm{R} \$ 550.689,23$ & $\mathrm{R} \$ 494.825,02$ & $\mathrm{R} \$ 419.693,87$ & $\mathrm{R} \$ 318.650,83$ & $\mathrm{R} \$ 195.683,75$ \\
\hline $\begin{array}{l}\text { (=) RESULTADO } \\
\text { ECONÔMICO }\end{array}$ & $\mathrm{R} \$ 794.765,59$ & $\mathrm{R} \$ 516.339,17$ & $\mathrm{R} \$ 297.621,52$ & $\mathrm{R} \$ 136.861,43$ & $\mathrm{R} \$ 38.279,30$ \\
\hline $\begin{array}{l}\text { Lucro/ Prejuízo na } \\
\text { transação }\end{array}$ & $\mathrm{R} \$ 310,77$ & $\mathrm{R} \$ 5.174,98$ & $\mathrm{R} \$ 306,13$ & $\mathrm{R} \$ 1.349,17$ & $\mathrm{R} \$ 4.316,25$ \\
\hline
\end{tabular}

Considerações: a partir da simulação do evento venda, apurou-se o resultado de cada período.

Neste caso, também, é possível identificar nos resultados do modelo qual o valor mínimo em que o jogador teria que ser negociado para que a transação se tornasse viável ao clube.

Como os jogadores representam um dos ativos mais valiosos do clube, a decisão de venda torna-se uma decisão importante. Normalmente, as decisões de vender encontram-se em função dos atletas adquiridos, atletas permutados ou atletas formados pelo clube.

Equação: Valor de Mercado > Resultado (Receita de Oportunidade -VPL (Recebimentos Pagamentos)). 


\subsubsection{Decisão de renegociação de contratos}

O processo de renegociação começa no término da formação ou da primeira contratação do atleta para o clube, uma vez que, ao final da vigência do contrato, o clube se vê diante de uma situação de decisão: continuar ou não com aquele atleta, será que, se houver renovação, o investimento trará retorno econômico, financeiro, operacional e esportivo satisfatório?

Há os riscos e a incerteza de retorno econômico, financeiro e esportivo, uma vez que o atleta contratado pode não se adaptar ao grupo, ao ambiente ou até se machucar na primeira partida após assinar o contrato.

A decisão de renegociação encontra-se classificada como uma sub-decisão, ou seja, encontrase em função de outras decisões, tais como: formação, contratação e empréstimo. Logo abaixo, apresenta-se o fluxo temporal que demonstra o momento em que os contratos e as possíveis renegociações acontecem, tanto para jogadores formados como para atletas profissionais adquiridos ou contratados pelo clube.

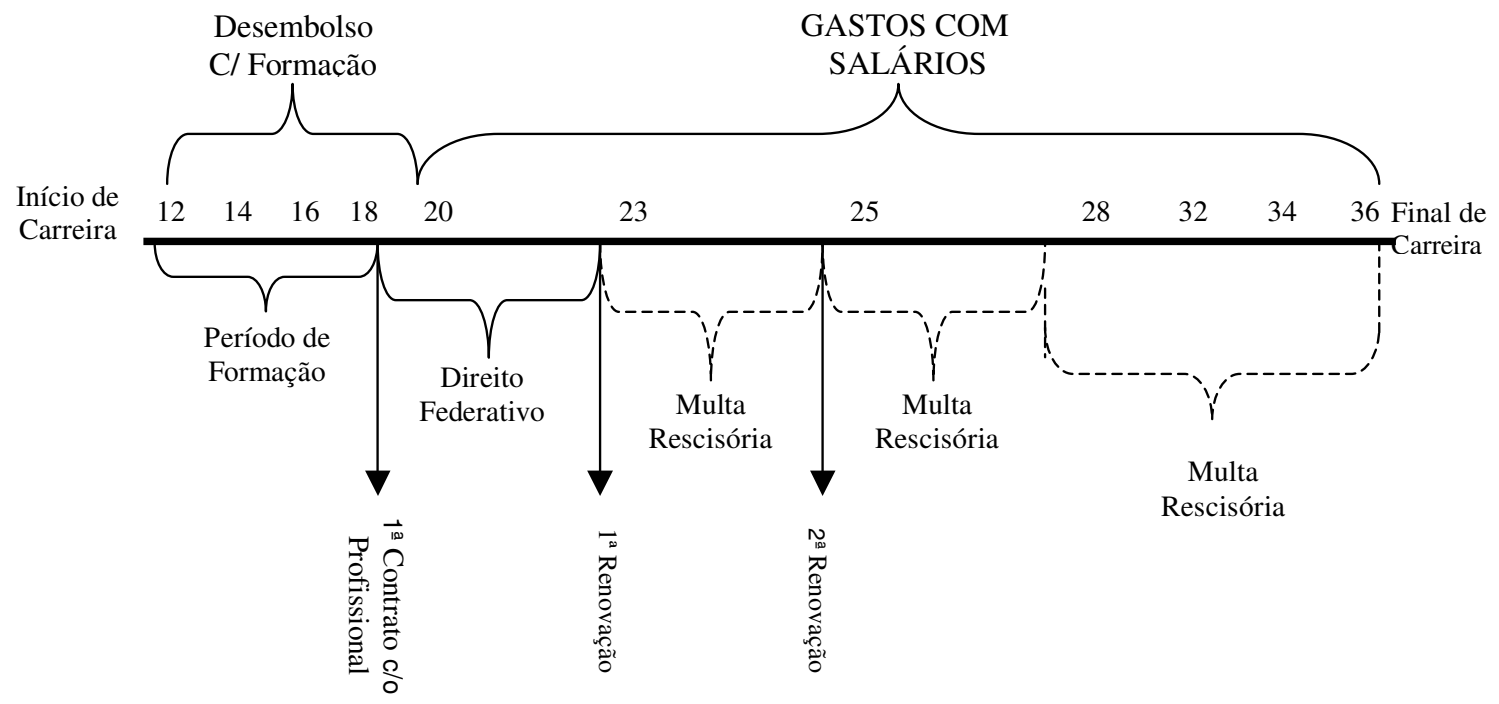

Figura 19 - Fluxo físico-operacional - contratos e renegociações 
A renegociação de contratos é uma decisão que acontece quando existem interesses entre as partes, neste caso, não se pretende realizar simulação numérica, tendo em vista que já foram realizadas simulações de compra / aquisição, empréstimo e formação, visto que este tipo de decisão é uma conseqüência de um evento e não difere das simulações já realizadas. 


\section{CONCLUSÃO}

O futebol pode ser visto como um negócio que se situa entre a competição e a cooperação entre os times. Assim, essas duas características do negócio deram origem a dois tipos de mercado nos quais atualmente o futebol opera: o mercado de jogadores e o de torcedores. No que diz respeito ao processo de negociação de jogadores, foram investigados os fenômenos e buscaram-se evidências que expliquem as indagações pretendidas.

Uma vez que as análises e considerações, tanto sobre o estudo de caso como sobre a solução proposta, já foram comentadas anteriormente, cabe agora conduzir a análise de forma que se relacionem as variáveis da pesquisa com o objeto pesquisado e a questão investigada. Ao final da análise, novas proposições tomarão a forma de questões para pesquisas futuras.

De acordo com as recomendações anteriores, torna-se essencial a utilização de ferramentas referentes ao estudo de caso, que demonstrem a relação com os objetivos da pesquisa: demonstrar as características ambientais, institucionais e organizacionais; diagnosticar pontos relevantes sobre o objeto pesquisado; servir de base para o desenvolvimento de novas pesquisas.

Para Yin (2001), no estudo de caso, o pesquisador não sabe de antemão os resultados esperados de sua pesquisa e todas as proposições iniciais são desenvolvidas com a profundidade necessária. O mais relevante é este tipo de pesquisa poder despertar alguns insights que levarão a novas questões de pesquisas.

No contexto abordado, conclui-se que os objetivos estabelecidos cumpriram o propósito para o qual foram determinados, pois ofereceram subsídios à busca de evidências (respostas) à questão investigada.

Diante da teoria da contabilidade e da teoria econômica, constatou-se que as formas de avaliação de ativos têm reflexos nas determinações do seu valor, sendo que o jogador não é diferente. Foram constatadas, com base na teoria, evidências de que o jogador de futebol representa um ativo para o clube, por atender ao conceito e às características de ativo. 
No que diz respeito à abordagem empírica, pôde-se verificar que este ativo deve ser gerenciado tendo em vista que as diversas decisões provocam impacto tanto no resultado como no patrimônio do clube.

Verificou-se que sobre este ativo são tomadas diversas decisões (eventos) que estão diretamente ligadas ao seu processo de gestão, sendo que cada decisão de fato provoca impacto econômico para o clube.

Deste modo, o trabalho chega à conclusão de que a hipótese assumida pode ser aceita de forma integral, "o jogador de fato é um ativo e gera benefícios econômicos para o clube”, pois atende aos conceitos e características de um ativo para a entidade.

No tocante às decisões, observou-se que os gestores têm consciência dos eventos, mas não possuem ferramentas que permitam mensurar os impactos de suas decisões. De forma específica, conclui-se que: os gestores têm consciência dos eventos e da sua necessidade de gerenciamento, mas não estabeleceram, até o presente momento, ferramentas que otimizem a eficácia da entidade; o clube não disponibiliza de um sistema de avaliação destes eventos.

Este trabalho pode auxiliar os gestores no planejamento, na avaliação da gestão de jogadores de futebol; a metodologia operacional adotada pelo clube na formação de atletas tem se mostrado eficiente pelo número de atletas revelados nos últimos anos. Deste modo, observouse a necessidade de uma metodologia que avalie a viabilidade econômica de cada decisão. A proposta apresentada objetiva disponibilizar ferramentas que, de forma estratégica, contribuam tanto para a eficácia quanto para a eficiência do clube, no tocante à gestão de seus ativos (jogadores).

Torna-se imprescindível também a realização de estudos sobre a gestão destes eventos para, assim, contribuir ao desenvolvimento das relações financeiras, econômicas e sociais do clube. Notou-se ainda que as constatações demonstradas pelo estudo de caso foram importantes ao entendimento de um segmento ainda não muito explorado.

Yin (2001) recomenda a repetição deste processo de construção da explicação do objeto de pesquisa, pois tende a consolidar as proposições teóricas até agora desenvolvidas e gerar novas proposições de pesquisas. 
Com relação ao objeto pesquisado, ficou evidente que o clube não disponibiliza um sistema de informações que auxilie as decisões sobre este ativo, demonstrando a sua necessidade.

Visto que o propósito fundamental da pesquisa foi entender como os clubes tomam as decisões econômicas (transações) com jogadores de futebol, bem como a carência de trabalhos científicos sobre o tema, os resultados obtidos devem ser analisados do ponto de vista de sua importância e de seus limites.

Desta forma, a contribuição maior da pesquisa foi oferecer um entendimento, mesmo que de forma incipiente, sobre o processo de avaliação e as variáveis que impactam o processo de negociação.

Diante de tais constatações, observa-se que o estudo se limita ao caso estudado e oferece uma proposta para que o gestor possa avaliar o impacto econômico das decisões (passadas, presentes e futuras) relacionado à gestão dos ativos (jogador).

O modelo proposto e desenvolvido pelo estudo tem como objetivo oferecer subsídios necessários para o gestor no processo decisório. No entanto, isto não garante que, se o investimento for realizado, poderá trazer o retorno mínimo desejado. Porém, o modelo permite ao gestor escolher dentre as alternativas disponíveis, qual trará melhor impacto no resultado do clube, escolhendo a mais viável à continuidade das operações da entidade.

Estruturados os modelos de identificação, mensuração e decisão dos eventos identificados, gerou-se uma contribuição teórica, já que trabalhos dessa natureza não foram ainda realizados, e uma contribuição prática, tendo em vista que os modelos propostos podem ser utilizados para elaboração de instrumentos que permitam aos gestores simular e mensurar o impacto de cada alternativa disponível e, deste modo, escolher aquela que proporcione o melhor resultado econômico para o clube.

Esta pesquisa aponta algumas vertentes para novos estudos, tais como: investigar os mesmos pressupostos verificados no caso do Clube Atlético Paranaense em outros clubes; realizar, sob essa mesma perspectiva, estudo comparativo entre outros clubes; além de realizar estudos relacionados à governança e viabilidade econômica de formação de atletas, dentre outras. 


\section{REFERÊNCIAS}

AIDAR, A. C. K. A transformação do modelo de gestão no futebol. Relatório N 16/2000, São Paulo: 2000.

ALENCAR, F. G. de. Contribuição ao tratamento contábil dos principais eventos de um ativo de exploração de reservas minerais: uma abordagem de gestão econômica. São Paulo, 1998. Dissertação (Mestrado em Ciências Contábeis). Faculdade de Economia, Administração e Contabilidade da Universidade de São Paulo.

ALMEIDA, L. B. de. Estudo de um modelo conceitual de decisão, aplicado a eventos econômicos, sob a ótica da gestão econômica. São Paulo, 1996. Dissertação (Mestrado em Ciências Contábeis). Faculdade de Economia, Administração e Contabilidade da Universidade de São Paulo.

ALMEIDA, R. J. Análise da importância dos direcionadores de valor das empresas para diferentes tomadores de decisão no Brasil. São Paulo, 2000. Dissertação (Mestrado em Ciências Contábeis). Departamento de Contabilidade e Atuária. Faculdade de Economia, Administração e Contabilidade da Universidade de São Paulo.

ANTUNES, M. T. P. Contribuição ao entendimento e mensuração do capital intelectual. São Paulo, 1999. Dissertação (Mestrado em Ciências Contábeis). Departamento de Contabilidade e Atuária. Faculdade de Economia, Administração e Contabilidade da Universidade de São Paulo.

ANTUNES, M. T. P.; MARTINS, E. Capital intelectual: verdade e mitos. Revista Contabilidade e Finanças. São Paulo, v. 31, 2002.

ARAGAKI, C. Transparência nas demonstrações contábeis de clubes de futebol - o caso do passe de atletas profissionais. Esporte Bizz: Negócios e Esporte. Dez. 2002. Disponível em: $<$ http://www.esportebizz.com.br/esporte_bizz/interna.asp>.

ARAÚJO, V. O Estado de São Paulo. Seção de Esporte. São Paulo, 3/04/2003.

BARBIERI, G. et al. Críticas aos métodos de avaliação a valores de entrada e de saída. Monografia apresentada à Disciplina Teoria da Avaliação Patrimonial, FEA/USP. São Paulo: S/d. (trabalho não publicado).

BATEMAN T. S.; SNEL S. A. Administração: construindo vantagem competitiva. 2 ed. São Paulo: Atlas, 1998. 
BETING, E., Entrevista com Mauro Holzman - sobre o Clube dos 13 e seu passado no Atlético Paranaense. Esporte Bizz: Negócios e Esporte. Dez. 2003. Disponível em: $<$ http://www.esportebizz.com.br/esporte_bizz/interna.asp $>$.

. Novo Código de Justiça desportiva faz caça a violência. Esporte Bizz: Negócios e Esporte. $\quad 2003 . \quad$ Dez. $<$ http://www.esportebizz.com.br/esporte_bizz/interna.asp $>$.

BRASIL. Lei $\mathbf{n}^{\mathbf{0}}$ 9.615, de 24 de março de 1998. (Lei Pelé). Disponível em <http://www.presidencia.gov.br/ccivil_03/Leis/L9615consol.htm>. Acesso em 2004.

Medida Provisória n. 79, de 27 de novembro de 2002. Diário Oficial da União de 28.11.2002. Disponível em <http://www.trt02.gov.br/geral/tribunal2/legis/MPV/79_02.html>. Acesso em 2004.

BRUMMET R. L. et al. Human resource measurement: a challenge for accountants. The Accounting Review. April, p. 217-224, 1968.

BRUNORO, J. C.; AFIF, A. Futebol 100\% profissional. São Paulo: Ed. Gente, 1997.

BUDOLLA, M. Gol! - a emoção aliada aos negócios. Curitiba: FAE/CDE, 1999.

CABALlERO L.; CARVALHO, S. A co-gestão esportiva no futebol: o caso Juventude Parmalat. Passo Fundo: Editora Ediupf, 1998.

CARRANO, P. C. R. et al. Futebol: paixão e política. Rio de Janeiro: DP\&A Editora, 2000.

CASTRO, L. R. M. Direito de imagem do atleta - conceito, alcance e riscos. Esporte Bizz: Negócios e Esporte. Dez. 2002. Disponível em: $<$ http://www.esportebizz.com.br/esporte_bizz/interna.asp>. Acesso em 17/12/2003.

CATELLI, A. (Coord.) Controladoria: uma abordagem da gestão econômica - GECON. 2. ed. São Paulo: Atlas, 2001.

CHAMBERS, R. J. Accounting, evaluation and economic behavior. Texas: Scholars Book, 1966.

Accounting, evaluation and economic behavior. Texas: Scholars Book, 1974.

CHIAVENATO, I. Recursos humanos. 5 ed São Paulo: Atlas, 1998.

CONN, D. The football business - fair game in the '90s? Mainstream Publishing Projects, Edinburgh, Inglaterra: 1998. 
DRUCKER. P. Administração, tarefas e responsabilidade. 3 ed. São Paulo: Pioneira, v. I, 1995.

EDVINSSON L.; MALONE M. S. Capital Intelectual: descobrindo o valor real de sua empresa pela identificação de seus valores internos. São Paulo: Makron Books, 1998.

FERNANDES, F. C. O modelo UEFA e lições para o modelo esportivo brasileiro. Esporte Bizz: Negócios e Esporte. Dez. 2002. Disponível em: $<$ http://www.esportebizz.com.br/esporte_bizz/interna.asp $>$.

FERREIRA, A. B. de H. Dicionário Aurélio escolar da língua portuguesa. Rio de Janeiro: Nova Fronteira, 1988.

FERREIRA, C. E. C. O modelo de governança do futebol europeu. Esporte Bizz: Negócios e Esporte. Disponível em: <http://www.esportebizz.com.br>. Acesso em 18/12/2003.

FISHER, Irving. The nature of capital and income: New York, Macillan, 1906. p. 52.

FLAMHOLTZ, E. G. Human resource accounting. 2nd ed. Jossey-Bass Publishers, 1985.

The impact of human resource valuation on management decisions: a laboratory experiment. Accounting, Organizations and Society. p. 153-166, February, 1976.

FYNN, A.; GUEST, L. For love or money: Manchester United and England - the business of winning? London, Inglaterra: Macmillan Publishers Ltd, 1998.

GALEANO, Eduardo. O Futebol. 1995. Disponível em: <http://www.contrapie.com/vercronicas.asp?id_cronica=476>. Acesso em 2004.

GARRED, Bill. As estratégias para receitas no futebol. Esporte Bizz: Negócios e Esporte. Dez. 2002. Disponível em: <http//www.esportebizz.com.br/esporte_bizz/interna.asp>. Acesso em dezembro 2003.

GIL, A. C. Métodos e técnicas de pesquisa social. São Paulo: Atlas, 1987.

GROJER J. E.; JOHANSON U. Current development in human resource costing and accounting, reality present, researchers absent. Accounting, Auditing and Accountability Journal. v. 11, n. 4, p. 495-505, 1998.

GRÖNROOS, C. Marketing: gerenciamento e serviços: a competição por serviços na hora da verdade. Rio de Janeiro: Ed. Campus, 1995. 
GUERREIRO, R. Modelo conceitual de sistema de informação de Gestão EconômicaGECON: uma Contribuição à teoria da comunicação da contabilidade. São Paulo, 1989. Tese (Doutorado em Ciências Contábeis). Faculdade de Economia, Administração e Contabilidade da Universidade de São Paulo.

GUERREIRO, R. Um modelo de sistema de informações contábil para mensuração do desempenho econômico das atividades empresariais. In: XIX Conferência Internacional de Contabilidade. Anais, Outubro, 1991.

Teoria das restrições e o sistema de gestão econômica: uma abordagem proposta de integração conceitual. São Paulo, 1995. Tese de Livre Docência - Faculdade de Economia, Administração e Contabilidade da Universidade de São Paulo.

HENDRIKSEN, E. S. Accounting theory. Illinois: Fourth Edition, 1982.

HENDRIKSEN, E.S.; VAN BREDA, M. L. F. Teoria da contabilidade. São Paulo: Atlas, 1999.

HORNGREN, C. T. Contabilidade de custos: um enfoque administrativo. São Paulo: Ed. Prentice Hall do Brasil, 1978.

IJIRI, Y. The foundations of accounting measurement. New Jersey: Prentice-Hall, 1967.

IUDÍCIBUS, S. de. Análise da correção monetária das demonstrações financeiras. São Paulo: Atlas, 1982.

Aspectos da avaliação de estoques a preços correntes. São Paulo, 1968. Tese de Livre Docência - Faculdade de Economia, Administração e Contabilidade da Universidade de São Paulo.

Contabilidade de custo. 4. ed. São Paulo: Atlas, 1992.

Contribuição à teoria dos ajustamentos. São Paulo, 1966. Tese (Doutorado em Ciências Contábeis). Faculdade de Economia, Administração e Contabilidade da Universidade de São Paulo.

. Teoria da contabilidade. 3. ed. São Paulo: Atlas, 1993.

. Teoria da contabilidade. 6. ed. São Paulo: Atlas, 2001.

2001.

.; MARION, J. C., Introdução à teoria da contabilidade. 2. ed. São Paulo: Atlas,

IUDÍCIBUS, S. de et al. Contabilidade introdutória. 7. ed. São Paulo: Atlas. 1990. 
IUDÍCIBUS, S. de et al. Manual de contabilidade das sociedades por ações. 5. ed. São Paulo: Atlas, 2000.

KAM, V. Accounting theory. California: Jonh Willey \& Sons, 1986.

KAPLAN, A., A conduta na pesquisa: metodologia para ciência do comportamento. São Paulo: Herder, 1972.

LAKATOS, E. M.; MARCONI, M. A. Metodologia do trabalho científico. 2. ed. São Paulo Atlas: 1991.

. Metodologia do trabalho científico. 3. ed. São Paulo: Atlas: 1994.

Metodologia do trabalho científico. 5. ed. São Paulo: Atlas: 2003.

LEONCINI, M. P. Entendendo o negócio Futebol: um estudo sobre a transformação do modelo de gestão estratégica nos clubes de futebol. São Paulo, 2001. Tese (Doutorado) Engenharia de Produção. EPRO.

LEONCINI, M. P.; SILVA, M. T. Futebol como fábrica de serviços. Encontro Nacional de Engenharia de Produção, $18^{\circ}$ Congresso Internacional de Engenharia Industrial. Anais. Niterói: UFF/TEP, 1999.

LUSTOSA, P. R. B. Um estudo das relações entre o lucro contábil, os fluxos realizados de caixa e o valor econômico da empresa: uma simulação aplicada a um banco comercial. São Paulo, 2001. Tese (Doutorado em Ciências Contábeis). Faculdade de Economia, Administração e Contabilidade da Universidade de São Paulo.

MACNEAL, K. Truth in Accounting. Lawrence, Kansas, U.S. 1970.

MARION, J. C. Contabilidade empresarial. 4. ed. São Paulo: Atlas, 1991.

MARTIN, J. Information engineering. England: Savant Research Studies, 1986.

MARTINS, E. Contribuição à avaliação do ativo intangível. São Paulo, 1972. Tese (Doutorado em Ciências Contábeis). Faculdade de Economia, Administração e Contabilidade da Universidade de São Paulo.

MARTINS, G. de A. Manual para elaboração de monografias e dissertações. São Paulo: Atlas, 1992. 
1994.

Manual para elaboração de monografias e dissertações. 2. ed. São Paulo: Atlas,

MARTINS, V. A., Contribuição à avaliação do GOODWILL: depósitos estáveis, um ativo intangível. São Paulo, 2002. Dissertação (Mestrado em Ciências Contábeis). Departamento de Contabilidade e Atuária, Faculdade de Economia, Administração e Contabilidade da Universidade de São Paulo.

MAXIMINIANO, A. C. A. Introdução à administração. 2. ed. Atlas, São Paulo: 1985.

MICHIE, J.; SHEEHAN, M. HRM Practices, R\&D expenditure and innovative investment: evidence from the 1990 Workplace Industrial Relations Survey (WIRS). Working Paper. The queen's University of Belfast Department of Economics, 1998.

MICHIE, J.; VERMA S. Accounting for footballers and football clubs. Paper for Conference on The Corporate Governance of Professional Football. London: Birkbeck College, February 3rd.

MICHIE, J.; VERNA WALSH, A. Ownership and governance options for footballers clubs. Paper for Conference on The Corporate Governance of Professional Football. London: Birkbeck College, February 3rd, 1999.

MILHER, R. L. Microeconomia: teoria, questões e aplicações. São Paulo: Ed. McGraw Hill do Brasil, 1981.

MIRANDA, L. C. Modelos de simulação empresarial. São Paulo, 1985. Dissertação (Mestrado em Ciências Contábeis). Departamento de Contabilidade e Atuária, Faculdade de Economia, Administração e Contabilidade da Universidade de São Paulo.

MONOBE, M. Contribuição a mensuração e contabilização do GOODWILL não adquirido. São Paulo, 1986. Tese (Doutorado em Ciências Contábeis). Faculdade de Economia, Administração e Contabilidade da Universidade de São Paulo.

MURAD, M. Dos pés à cabeça. Elementos básicos de sociologia do futebol. Rio de Janeiro: Editora Irradiação Cultural Ltda., 1996.

NELO, Ana Maria. Avaliação de estoques a valores de entrada e de saída. São Paulo, 1996. Dissertação (Mestrado em Ciências Contábeis). Departamento de Contabilidade e Atuária, Faculdade de Economia, Administração e Contabilidade da Universidade de São Paulo.

NETO, F. P. M. Administração e marketing de clubes esportivos. Rio de Janeiro: Ed. SPRINT, 1998. 
NETO MORAES, G., Dossiê de 50 - os onze jogadores revelam os segredos da maior tragédia do futebol brasileiro. Rio de Janeiro: Objetiva, 2000.

NORMANN, R. Administração de serviços. São Paulo: Ed. Atlas, 1993.

OLIVEIRA, A. B. S. Contribuição à formulação de um modelo decisório para intangíveis por atividade - uma abordagem de gestão econômica. São Paulo, 1999. Tese (Doutorado em Ciências Contábeis). Faculdade de Economia, Administração e Contabilidade da Universidade de São Paulo.

PACHECO, V. Uma contribuição ao estudo da contabilidade recursos humanos e seu poder de informação. São Paulo, 1996. Dissertação (Mestrado em Ciências Contábeis). Departamento de Contabilidade e Atuária, Faculdade de Economia, Administração e Contabilidade da Universidade de São Paulo.

PADOVEZE, C. L. Contabilidade gerencial: um enfoque em sistema de informação contábil. 3. ed. São Paulo: Atlas, 2000.

PEREIRA, A. C. et al. Custo de oportunidade: conceitos e contabilização. Caderno de Estudos FIPECAFI. São Paulo, FEA/USP, abril 1990.

PEREIRA, C. A. Contribuição à elaboração de um modelo de mensuração aplicado aos modelos de decisão dos principais eventos econômicos de instituições financeiras: uma abordagem da gestão econômica. São Paulo, 2000. Tese (Doutorado em Ciências Contábeis). Faculdade de Economia, Administração e Contabilidade da Universidade de São Paulo.

REDIG, P. Brasil e Argentina se unem para driblar a crise. Esporte Bizz: Negócios e Esporte. Dez. 2002. Disponível em: <http://www.esportebizz.com.br/esporte_bizz/interna.asp>. Acesso em novembro 2003.

REIS, E. A. Aspectos da depreciação de ativos sob a ótica da gestão econômica. São Paulo, 1997. Dissertação (Mestrado em Ciências Contábeis). Departamento de Contabilidade e Atuária, Faculdade de Economia, Administração e Contabilidade da Universidade de São Paulo.

REZENDE, A. J.; PEREIRA, C. A. A mensuração de atletas nas demonstrações dos clubes. EPAC - Encontro de Pesquisa em Administração e Contabilidade. Anais, São Paulo, 2003

Uma análise quantitativa sobre a performance esportiva e operacional dos clubes brasileiros. EPAC - Encontro de Pesquisa em Administração e Contabilidade. Anais, São Paulo, 2003.

ROBERTO EDWARDS, E. O.; BELL. P. W. The theory and measurement of business income.Los Angeles: University of California Press, 1973. 
ROCHA, M. M. Integração vertical e incerteza. São Paulo, 2002. Dissertação (Mestrado em Economia). Faculdade de Economia, Administração e Contabilidade da Universidade de São Paulo.

ROCHA, W. et al. Teoria da mensuração e controladoria. Monografia apresentada à disciplina Introdução à Controladoria, FEA/USP. São Paulo, 1994 (trabalho não publicado).

SANTOS, M. L. V. V. A evolução da gestão no futebol brasileiro. São Paulo, 2002. Dissertação (Mestrado em Administração). Escola de Administração de Empresas de São Paulo, Fundação Getúlio Vargas.

SIFFERT FILHO, N. F. A teoria dos contratos econômicos e a firma. São Paulo, 1996. Tese (Doutorado em Economia). Faculdade de Economia, Administração e Contabilidade da Universidade de São Paulo.

SILVA, A. dos S. Análise das formas de reconhecimento da receita na contabilidade: um enfoque econômico de lucro. Dissertação (Mestrado em Ciências Contábeis). Departamento de Contabilidade e Atuária, Faculdade de Economia, Administração e Contabilidade da Universidade de São Paulo. 2000.

SILVA, W, D. da. Contribuição à mensuração e evidenciação nos relatórios contábeis do valor dos contratos com atletas de futebol para as sociedades desportivas: um estudo de caso no Sport Clube Corinthians Paulista. Dissertação (mestrado em controladoria e contabilidade estratégica) Centro Universitário Álvares Penteado - UNIFECAP. 2004.

SLOMSKI, V. Manual de contabilidade pública: um enfoque na contabilidade municipal. São Paulo: Editora Atlas, 2001a.

Mensuração do resultado econômico nas entidades públicas: uma proposta. Chapecó: SC Arcos Editora Universitária, 2001b.

Resultado econômico: um novo paradigma na administração pública. Revista do CRC/SC. Florianópolis/SC, v. 1, março, 2002.

Teoria do agenciamento no estado: uma evidenciação da distribuição de renda econômica produzida pelas entidades públicas de administração direta. São Paulo, 1999. Tese (Doutorado em Controladoria e Contabilidade). Faculdade de Economia, Administração e Contabilidade da Universidade de São Paulo.

STERMOLE, F J.; STERMOLE, J. M. Economic evaluation and investment decision methods. 7th ed. Colorado: Investments Evaluations Corporations, golden, 1990.

STEWART, Thomas A. Capital intelectual: a nova vantagem competitiva das empresas. Rio de Janeiro: Campus, 1998. 
SUNDER, Shyan. Theory of accounting and control, Ohio. South-Western College Publishing, 1997.

SZUSTER, A. P. Contribuição para aprimoramento da informação contábil dos clubes desportivos brasileiros. IOB - Temática contábil, n. 7, ano XXXV, $1^{\mathrm{a}}$ semana, novembro, 2001.

SZYMANSKI, S.; KUYPERS, T. Winners and losers - the business strategy of football. Inglaterra: Penguin Group, 1999.

TAYLOR, R. As dimensões sociais do relacionamento comercial entre os clubes de futebol e suas comunidades. In: I Congresso Internacional EAESP de Gestão de Esportes. Anais, São Paulo, Fundação Getúlio Vargas, 1998.

VIANA, E. O poder no esporte. Rio de Janeiro: Sprint, 1994.

YIN, R. K. Estudo de caso, planejamento e métodos. 2. ed. Porto Alegre: Bookman, 2001.

ZIMMERMAN, J. L. Accounting for Decision Marking and Control. Irwin, 1995. 


\section{APÊNDICES}

Apêndice 1 - Roteiro - Levantamentos das Atividades Operacionais - Clube Atlético Paranaense 


\section{APÊNDICE 1}

\section{ROTEIRO}

\section{LEVANTAMENTOS DAS ATIVIDADES OPERACIONAIS \\ CLUbE ATLÉtico PARANAENSE}

\section{AMBIENTE EXTERNO (ATUAL / TENDÊNCIAS)}

1.1 Quais são os Mercados?

1.2 Quais são os Clientes?

1.3 Quais são os Fornecedores?

1.4 Quais são os principais Concorrentes?

1.5 Qual a tecnologia utilizada atualmente pelo clube em suas atividades?

1.6 Qual influência do governo nas atividades do clube?

1.7 Quais são as Legislações vigentes e sua influência nas atividades do clube etc.

1.7.1 Em relação às atividades esportivas (relação do atleta com clube)?

1.7.2 Em relação aos aspectos financeiros e econômicos (demonstrações financeiras / publicações)?

1.7.3 Em relação aos direitos dos torcedores?

\section{AMBIENTE INTERNO}

2.1 Sistema Institucional

2.1.1 Qual é a Missão do clube? (razão de ser)

2.1.1.1 Qual grau de formalização (é documentada/registrada)

2.1.2 Quais são os planos do clube para o futuro?

2.1.3 Existe planejamento estratégico? Visão (imagem futura)?

2.1.3.1 Qual grau de formalização (é documentada/registrada)?

2.1.4 Existe planejamento operacional? Visão (presente)?

2.1.4.1 Qual grau de formalização (é documentada/registrada)?

2.1.5 Existe um processo de planejamento, execução, controle e avaliação deste plano e do planejamento no Clube Atlético Paranaense?

2.1.6 Quais são os horizontes do clube (aonde o clube quer chegar)?

2.1.7 Quais são os objetivos do clube?

2.1.8 Qual o Modelo de Gestão adotado pelo Atlético PR?

2.1.8.1 Quais são os gestores que estão atuando nesta gestão? e Quais são as áreas?

2.1.8.2 Qual o grau de autonomia destes gestores? Existe a delegação atualmente no clube?

2.1.8.3 Este modelo de gestão é formalizado, documentado?

2.1.9 Existe manual de normas e procedimentos para gestão e função destes gestores?

2.1.10 Existem critérios de avaliação de desempenhos para gestão e para o trabalho dos gestores? E quais são os indicadores e critérios?

\section{3 - SISTEMA ORGANIZACIONAL}

3.1 Atualmente existe organograma do clube?

3.2 Quais são as Áreas? 
3.3 Quais são os departamentos /quem são seus responsáveis?

3.4 Principais funções de cada área / depto.

3.5 Existem relacionamentos entre as atividades (Medicina esportiva - serviço de apoio treinamento - arena) - (fluxograma preliminar)? De que maneira isto ocorre?

\section{4 - SISTEMA SOCIAL (RECURSOS HUMANOS)}

4.1 Os gestores têm qualificação técnica apropriada?

4.1.1 Qual a qualificação de cada gestor?

4.2 Existe um processo de qualificação técnica para os atletas?

4.2.1 Qual é? E como é feita a qualificação técnica para jogadores:

4.2.1.1 Em formação?

4.2.1.2 E jogadores profissionais?

4.2.2 Existe uma política de motivação organizacional (Clima organizacional / motivação)?

4.2.3 Descreva qual é a política de motivação para os atletas?

4.2.4 Existe Participação em projetos sociais, qual a participação dos atletas?

4.2.5 Qual é o processo de educação e lazer dos atletas (tanto profissional como amador)?

4.2.6 Existe uma política de promoção / remuneração, para atletas profissionais e amadores?

4.2.7 Existem faixas de salários, como funciona?

\section{5 - SISTEMA FÍSICO-OPERACIONAL}

5.1 Quais são os principais eventos de cada atividade ligada ao futebol profissional e amador?

5.2 Quais são as principais decisões (eventos econômicos) em cada atividade da área?

5.3 Como ocorre cada evento, poderia brevemente descrever cada evento?

5.4 Como ocorre o processo de compra ou contratação de atletas?

5.5 Como ocorre o processo de formação de atletas?

5.6 Como ocorre o processo de venda de atletas - qual momento?

5.7 Como ocorre o processo de empréstimo de atletas? Quando deve emprestar, e por que o clube empresta?

5.8 Como ocorre o processo de renegociação de contratos? Quando renegociar? Antes do vencimento durante o campeonato ou depois do término? Qual momento em que o Atlético inicia o processo de renegociação?

5.8.1 O que se deve levar em consideração na hora da renegociação do contrato?

5.8.1.1 Para o Atleta Profissional?

5.8.1.2 Para o Atleta amador?

5.9 Quais são os recursos consumidos por cada evento (Recursos / Produtos de cada atividade)?

5.10 Quais são as variáveis operacionais, econômicas, financeiras e patrimoniais de cada decisão (evento econômico)? e quais são seus impactos?

\section{6 - SISTEMAS DE INFORMAÇÕES}

6.1 Existe um Sistema de Informações Operacionais para os eventos (comprar, vender, emprestar, renegociar)?

6.2 Qual é o Nome?

6.3 Qual é a Finalidade?

6.4 Quais são os usuários? 
6.5 Qual a Tecnologia deste sistema de informações (informatizado - (planilhas/ software), manual)?

6.6 Como ocorre o processo de Entrada de Dados?

6.7 Produzem Relatórios / existe um Banco de Dados (saída) sobre estes eventos?

6.8 Existe um planejamento para a contratação de atletas?

6.9 Existe um planejamento para a venda de atletas?

6.10 Como é realizado?

6.11 Quando os atletas são negociados?

6.12 Por que são negociados de fato?

6.13 Existe um Sistema de Informações Econômico-financeiro utilizado pelo clube?

6.14 Existe um sistema de Contabilidade formal?

6.15 Quais são os relatórios?

6.16 Existe um sistema de Contabilidade gerencial?

6.17 Este sistema auxilia nas decisões e gestão destes ativos (jogadores)?

6.17.1 Como?

6.18 O clube realiza a elaboração e implementação de Orçamento?

6.18.1 É realizado: acompanhamento, comparação e avaliação das metas e planos estabelecidos no orçamento?

6.18.2 Quais são os indicadores utilizados?

6.19 Existe Contabilidade de custos?

6.19.1 Apura-se o custo do atleta profissional e amador?

6.20 Qual sistema de custo é utilizado nas apurações?

6.20.1 Qual a Finalidade?

6.20.2 Quais são os Usuários?

6.20.3 Existe uma tecnologia utilizada na apuração dos custos?

6.20.4 Como ocorre o processo de Entrada de Dados?

6.20.5 Produzem Relatórios / existe um Banco de Dados (saída) sobre os custos?

\section{7- SISTEMA ECONÔMICO-FINANCEIRO}

\subsection{PROCESSO FÍSICO-OPERACIONAL}

7.1.1 Processo de formação e treinamento de atletas - CT.

7.1.2 Qual a idade mínima para participar do processo de formação?

7.1.3 Quais são os testes realizados pelo Clube Atlético Paranaense, na seleção de atletas, para as categorias de base?

7.1.4 Quais são as fases?

7.1.5 Qual o tempo de duração do processo de formação?

7.1.6 Quais são os pré-requisitos necessários para ser aprovado?

7.1.6.1 Existe uma escala de pontuação?

7.1.6.2 Como funciona?

7.1.6.3 Qual a probabilidade de ascensão para outras categorias?

7.1.6.4 É possível medir a probabilidade de ascensão do atleta por idade?

7.1.6.4.1 Qual é a probabilidade média de cada idade e categoria?

7.1.6.4.2 Como funciona o cálculo?

7.1.7 Quais são os recursos consumidos nos testes?

7.1.8 Em média quantos jogos um jogador fica suspenso por contusões num campeonato?

7.1.9 Quais são as variáveis importantes no evento - FORMAÇÃO?

7.1.10 O talento/ habilidade do atleta? Idade?

7.1.11 O valor a ser investido - desembolso necessário - o custo de formação? 
7.1.12 Está ligado aos objetivos operacionais (atender a demanda interna)?

7.1.13 Está ligado aos objetivos operacionais (atender a demanda externa) Aspectos psicológicos, médicos, físicos, comportamentais?

7.1.14 Quando o clube adquire um determinado jogador, qual (ais) realiza (m) uma avaliação esportiva?

7.1.15 Quais parâmetros são considerados?

\section{8 - A GESTÃO DE JOGADORES DE FUTEBOL}

8.1 Qual o custo de formação de um atleta infantil, juvenil, júnior?

8.2 Quais são os recursos consumidos no dia-a-dia de formação dos atletas?

8.2.1 O que é consumido? Existem estatísticas destes consumos?

8.3 Qual o custo de um atleta profissional?

8.3.1 Quais são os recursos consumidos (treinamento, alimentação, alojamento, medicina esportiva) mês?

8.4 O Atlético Paranaense possui um modelo de gestão para o gerenciamento dos ativos ou investimentos realizados?

8.5 Qual modelo utilizado?

8.6 Quando o clube adquire um determinado jogador, qual (ais) análise(s) é/são realizadas pelo clube:

8.6.1 Realiza uma análise Financeira? Quais parâmetros são considerados?

8.6.2 Realiza uma análise Econômica? Quais parâmetros são considerados?

8.6.3 Realiza uma análise Operacional? Quais parâmetros são considerados?

8.6.4 Realiza uma avaliação Esportiva? Quais parâmetros são considerados?

8.6.5 Uma vez realizado um investimento, formação ou aquisição, o clube realiza um acompanhamento financeiro - econômico do investimento?

8.7 A depreciação econômica dos atletas é algo aplicado pelos clubes no gerenciamento dos atletas?

8.8 Como a contabilidade societária reconhece contabilmente o jogador de futebol, "demonstrações financeiras"?

8.9 Qual abordagem contábil para jogadores formados, como reconhecem/contabilizam este evento?

8.10 Qual abordagem contábil para jogadores adquiridos, como reconhecem/contabilizam este evento?

8.11 Qual abordagem para a multa rescisória (transferências de jogadores), como reconhecem este evento?

8.12 Para os contratos com vencimentos após a lei?

8.13 Para os contratos firmados após a lei?

8.14 Na gestão dos ativos humanos (formação, aquisição e empréstimo), quais são as análises realizadas pelo clube?

8.15 Qual a contribuição esportiva do jogador para o clube?

8.16 Qual o retorno financeiro e econômico investimento? E qual o prazo do retorno (curto, médio ou longo)?

8.17 Qual a capacidade de geração de fluxo de caixa?

8.18 Quais são as possibilidades de exploração da imagem do atleta?

8.19 Qual o grau de satisfação da torcida com relação àquela contratação Atleta?

8.20 Existe uma metodologia explícita de avaliação do valor dos jogadores de futebol no Clube Atlético PR?

8.21 Qual é a metodologia para determinar o valor do jogador?

8.22 Quais parâmetros são utilizados (mercado/ custo)? 
8.23 Qual método de avaliação (valor econômico, financeiro) utilizada pelo Atlético Paranaense para avaliar seus jogadores? (profissionais)

8.24 Este critério sempre foi utilizado? Por quê?

8.25 Qual era outra forma de avaliação? Por que mudou?

8.26 Qual método de avaliação (valor econômico, financeiro) utilizado pelo Atlético Paranaense para avaliar os jogadores formados pelo clube?

8.27 Este critério sempre foi utilizado? Desde quando?

8.28 Qual era outra forma de avaliação? Por que mudou?

8.29 Quais são os fatores, parâmetros que vocês consideram para determinar o valor do jogador?

8.30 Na compra ou contratação?

$8.31 \mathrm{Na}$ venda?

8.32 No empréstimo?

8.33 Na renegociação dos contratos?

\section{9 - QUAIS VARIÁVEIS SÃo RELEVANTES NO PROCESSO DE NEGOCIAÇÃO?}

9.1 O evento - aquisição ou contratação:

9.1.1 O talento ou habilidade é importante?

9.1.2 Os salários a serem desembolsados?

9.1.3 Desembolso inicial (multa contratual)?

9.1.4 Desembolso inicial (direito federativo)?

9.1.5 Prêmios pagos?

9.1.6 Bicho?

9.1.7 Direito de imagem?

9.1.8 Direito de arena?

9.1.9 Performance atual?

9.1.10 O histórico do jogador é aspecto importante (clubes onde atuastes, $n .^{\circ}$ de títulos conquistados e gols marcados, cartões, expulsões)?

9.1.11 Idade é uma variável importante?

9.1.12 Os aspectos psicológicos, médicos, físicos, comportamentais?

9.2 Quais são as variáveis importantes no evento - VENDA?

9.1.13 O preço de mercado?

9.1.14 A idade do jogador?

9.1.15 É uma política do clube repassar os atletas (devido às limitações financeiras, econômicas e operacionais do clube)?

9.1.16 Aproveitar a oportunidade - momento em que se encontra o atleta?

9.1.17 Processo de liquidação - necessidades financeiras do clube?

9.1.18 Devido à procura?

9.3 Quais são as variáveis importantes no evento - EMPRÉSTIMOS (concessão)?

9.3.1 Valor recebido pelo negócio?

9.3.2 O tempo de empréstimo? - as limitações contratuais?

9.3.3 A necessidade operacional/esportiva do clube?

9.3.4 A capacidade financeira em que se encontra o clube (boa opção)?

9.4 Quais são as variáveis importantes no evento - EMPRÉSTIMOS (obtenção)?

9.4.1 Valor a ser desembolsado?

9.4.2 O tempo de empréstimo? - as limitações contratuais? 
9.4.3 Os salários que serão pagos?

9.4.4 A necessidade operacional/esportiva do clube

9.4.5 A capacidade financeira em que se encontra o clube (boa opção)?

9.4.6 Aspectos relacionados à exploração da imagem do atleta são importantes? 


\section{ANEXOS}

Anexo A - Dados coletados do Clube Atlético Paranaense 
ANEXO A 